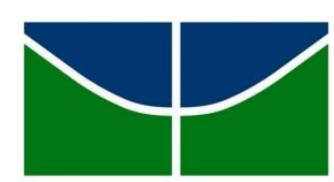

Universidade de Brasília (UnB)

Faculdade de Economia, Administração e Contabilidade (FACE)

Programa de Pós-Graduação em Economia

Mestrado Profissional em Economia e Gestão Pública

JHONATHAN DIVINO FERREIRA DOS SANTOS

\title{
VALORAÇÃO ECONÔMICA DE SERVIÇOS DE INFORMAÇÃO
}




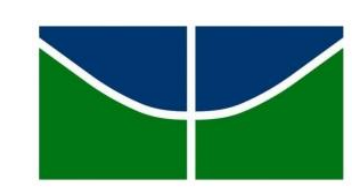

Universidade de Brasília (UnB)

Faculdade de Economia, Administração e Contabilidade (FACE)

Programa de Pós-Graduação em Economia

Mestrado Profissional em Economia e Gestão Pública

\section{VALORAÇÃO ECONÔMICA DE SERVIÇOS DE INFORMAÇÃO}

Dissertação de Mestrado apresentada ao Programa de Pós-Graduação em Economia da Faculdade de Economia, Administração e Contabilidade da Universidade de Brasília, como parte dos requisitos para obtenção do título de Mestre em Economia.

Orientadora: Prof. Dra. Denise Imbroisi 


\section{AGRADECIMENTOS}

Agradeço a Deus, pelas oportunidades e providências.

Agradeço ao Ipea, pela oportunidade de realizar esse Mestrado Profissional.

Agradeço à minha orientadora, Denise Imbroisi, pelas valiosas informações, pela paciência e pela parceria na realização dessa dissertação.

Agradeço à minha família e, em especial, à minha noiva Larissa Carvalho, pelo amor, compreensão, incentivo e parceria que foram fundamentais, não apenas durante o período de escrita, mas por todos os momentos da vida.

Agradeço aos meus amigos da turma, em especial Anna Ribeiro, Fernando Brustolin e Pedro Cavalcanti, pela parceria durante o período de estudo e pela parceria de todos esses anos também no trabalho.

Agradeço aos amigos de trabalho na Biblioteca do Ipea, em especial minha chefe Lúcia Lemos, que se aventuram comigo nessa jornada de descobertas a respeito da biblioteca do século XXI.

E, por fim, agradeço a todos os bibliotecários, colegas de profissão, que trabalham todos os dias na defesa e atualização da profissão. A todos os bibliotecários que não se acomodam, mas que, pelo contrário, lutam por uma profissão melhor, eu dedico essa dissertação. 


\section{RESUMO}

Trata-se de uma pesquisa bibliométrica que estuda a literatura sobre valoração econômica de bibliotecas. A elaboração desse estudo foi divida em duas partes. Na primeira parte do estudo, são apresentados conceitos relativos ao contexto político e econômico da Sociedade da Informação e aos métodos de valoração de bens intangíveis encontrados na literatura econômica, sobretudo nos estudos da Economia do Meio-ambiente. Na segunda parte do estudo é realizado um estudo de caso de valoração econômica de bibliotecas, tendo como foco a indicação de métodos encontrados na literatura para a valoração da Biblioteca do Instituto de Pesquisa Econômica Aplicada. Para a realização do estudo de caso, foram recuperados 39 textos em inglesa e espanhola, os quais foram resumidos e tabulados. Após análise das informações recuperadas nos textos, foram selecionados para a indicação alguns métodos de valoração que mais se adéquam ao contexto da Biblioteca do Instituto.

Palavras-chave: Valor Econômico, Métodos de Valoração Econômica, Bibliotecas 


\begin{abstract}
This is a bibliometric research, studying the literature on economic valuation of libraries. The preparation of this study was divided into two parts. In the first part of the study, concepts for the political and economic context of the Information Society are presented. It is also presented the valuation methods of intangible assets found in the economic literature, especially in studies of Economy of the environment. In the second part of the study we conducted a case study of economic valuation of libraries, focusing on the indication of methods found in the literature for the valuation of the Institute of Applied Economic Research Library. To conduct the case study, they were recovered 39 texts in English and Spanish, which were summarized and tabulated. After analyzing the information retrieved in the texts, were selected for displaying some valuation methods which are more suited to the Institute's Library context.
\end{abstract}

Keywords: Economic Value, Methods of Economic Valuation, Libraries 


\section{LISTA DE QUADROS}

Quadro 1: Resumo dos dados recuperados na literatura de valoração econômica de bibliotecas .. 57

Quadro 2: Opinião dos autores quanto ao valor de não-uso.................................................73

Quadro 3: Resumo das sugestões de métodos de valoração para a Biblioteca do Ipea............. 80 


\section{LISTA DE FIGURAS}

Figura 1: Representação gráfica dos idiomas dos documentos encontrados...........................55

Figura 2: Representação gráfica dos tipos de documentos recuperados .................................56

Figura 3: Representação gráfica da evolução da quantidade de estudos .................................71

Figura 4: Panorama da valoração econômica de bibliotecas ................................................ 72

Figura 5: Representação gráfica da distribuição dos tipos de biblioteca................................. 73

Figura 6: Representação gráfica dos objetos valorados......................................................... 74 


\section{SUMÁRIO}

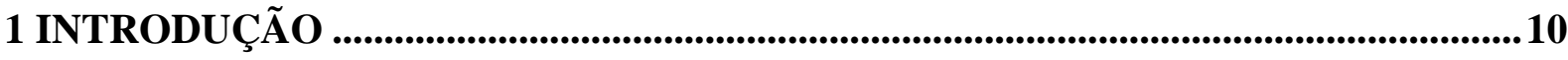

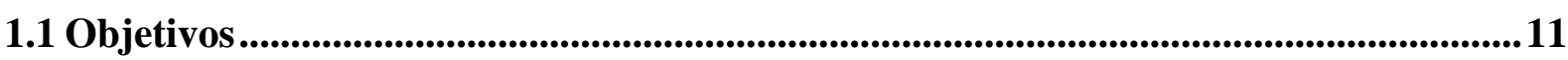

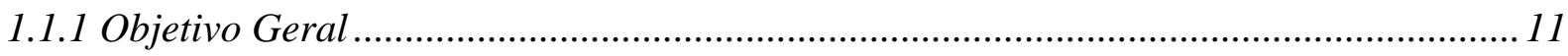

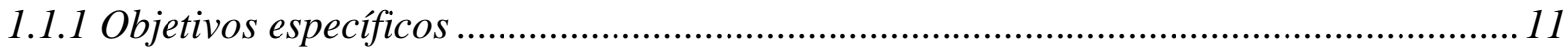

2 A SOCIEDADE E A ECONOMIA DA INFORMAÇÃO E DO CONHECIMENTO.. 12

2.10 contexto político-social da sociedade da informação..................................................12

2.1.1 Iniciativas para a sociedade global da informação ...................................................... 14

2.2 A abordagem macroeconômica da sociedade da informação......................................16

2.2.1 A informação e o conhecimento na nova economia ...................................................... 17

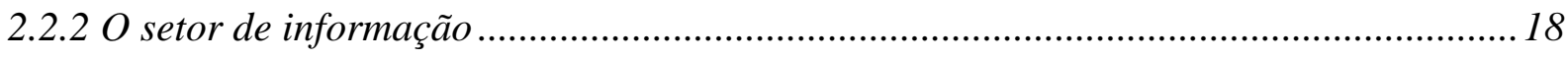

2.3 A abordagem microeconômica da sociedade da informaçãa............................................21

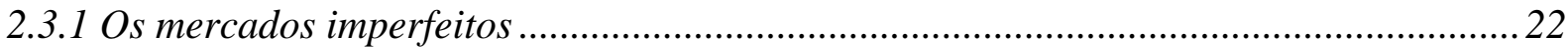

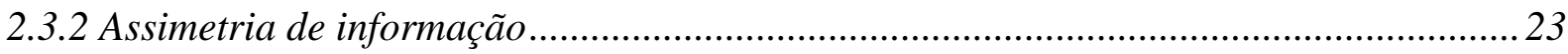

2.3.3 A assimetria de informação e os custos de transação ....................................................2

2.4 Características dos bens de informação ................................................................................28

3 MÉTODOS DE VALORAÇÃO DE BENS INTANGÍVEIS .............................................30

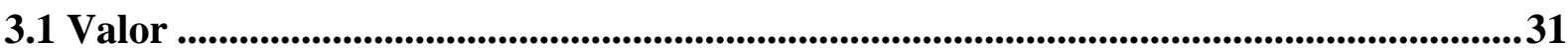

3.2 Valoração econômica de bens intangíveis e o legado da economia do meio ambiente ..... 32

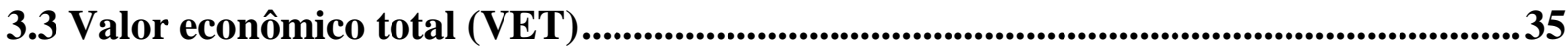

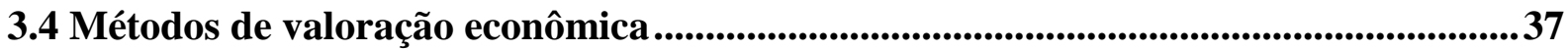

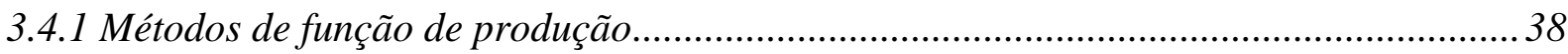

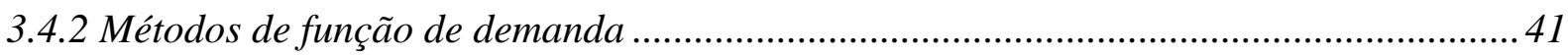

3.5 O uso dos métodos de valoração em outros contextos.....................................................44

4 BIBLIOTECAS: ORGANIZAÇÕES EM MUDANÇA.............................................46

4.1 A relevância dos serviços de informação...............................................................................49

4.2 Valor social das bibliotecas........................................................................................................51

5 ESTUDO DE CASO: VALORAÇÃO ECONÔMICA DE BIBLIOTECAS....................54

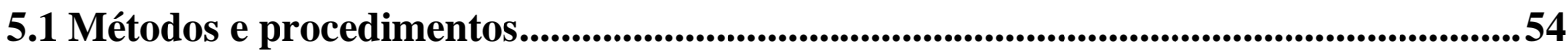

5.2 Valoração econômica de bibliotecas ................................................................................56

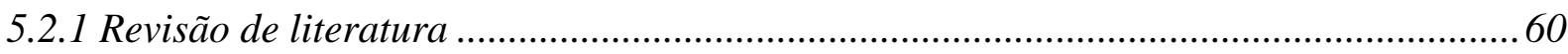

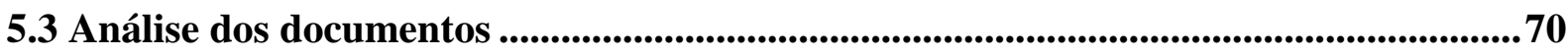

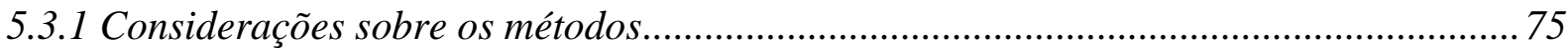


5.4 Proposição de métodos de valoração econômica para a Biblioteca do Ipea .76

5.4.1 O Instituto de Pesquisa Econômica Aplicada (Ipea)..................................................... 76

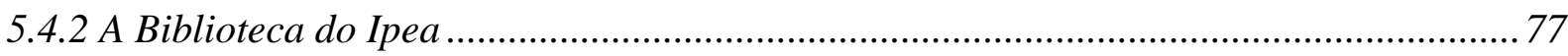

5.4.3 Proposição de métodos de valoração econômica ........................................................... 78

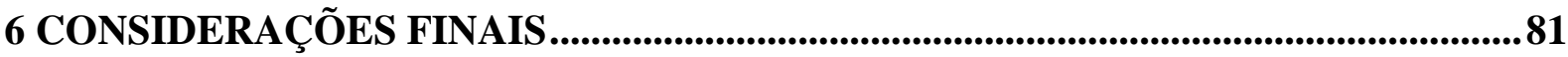

REFERÊNCIAS BIBLIOGRÁFICAS ......................................................................................84 


\section{INTRODUÇÃO}

O advento da sociedade atual, também conhecida como Sociedade da Informação, significou uma grande quebra de paradigma com a sociedade industrial. A evolução da tecnologia de informação teve uma grande importância para o desenvolvimento dessa sociedade, assim como a evolução dos setores de telecomunicação, o crescimento das redes de informação e a popularização da internet. A informação passou a ter caráter estratégico e o acesso à informação passou a ser sinônimo de desenvolvimento. Todos esses fatores permitiram o crescimento exponencial da produção, uso e acesso à informação, gerando assim uma 'explosão informacional', com proporções nunca vistas pela humanidade.

Com a economia girando em torno da produção e do acesso à informação, muitas profissões foram criadas e muitas permaneceram ativas, ganhando relativa importância diante de um mercado de informação crescente. Esse foi o caso dos bibliotecários, que passaram a dividir a gestão do ciclo informacional com outros profissionais. O crescimento massivo das tecnologias de informação e comunicação mudou o cenário e modificou a relação dos indivíduos com a informação. Dessa forma, o trabalho dos profissionais da informação está sujeito a mudanças constantemente.

Diante desse novo paradigma, os serviços de informação tradicionais passaram a ser associados a um modelo antiquado de recuperação da informação, gerando o pensamento de que é possível conseguir qualquer tipo de informação de forma gratuita na internet. Nesse contexto, as bibliotecas são solicitadas constantemente a apresentar resultados dos investimentos que recebem, sujeitas a risco de serem fechadas e a sucumbirem diante das tecnologias de informação. Nesse contexto, discutir o valor econômico das bibliotecas na sociedade atual é o tema principal dessa dissertação.

Esse tema traz consigo muitas discussões relativas ao papel das bibliotecas na sociedade atual. Será que ainda existe espaço pra bibliotecas no mesmo formato que elas possuem tradicionalmente? Será que a internet e as tecnologias de informação são de fato concorrentes dos serviços de biblioteca? Investir em bibliotecas tem um retorno financeiro positivo? É possível medir o retorno financeiro de bibliotecas? E, ainda, é possível medir o valor das bibliotecas?

As discussões de todas essas questões são abordadas nos capítulos dessa dissertação. Este trabalho está estruturado em 6 capítulos, incluindo essa Introdução e os objetivos que serão apresentados a seguir. O tema é introduzido a partir da apresentação do 
conceito de economia da informação, tanto em nível macroeconômico, quanto no nível microeconômico, no capítulo 2. O capítulo 3 apresenta o legado da Economia do Meio Ambiente na tentativa de atribuir um valor econômico a bens públicos e bens intangíveis. $\mathrm{O}$ capítulo 4 apresenta as principais características das bibliotecas, bem como suas classificações e principais produtos e serviços disponibilizados por elas. O capítulo 5 apresenta o estudo de caso, formado por uma revisão de literatura seguida de uma análise bibliométrica e da indicação de métodos para a valoração da Biblioteca do Instituto de Pesquisa Econômica Aplicada (Ipea). Por fim, o capítulo 6 apresenta as considerações finais desse estudo, retomando questões relevantes apresentadas durante toda a dissertação.

\subsection{Objetivos}

Os objetivos desta pesquisa estão descritos a seguir.

\subsubsection{Objetivo Geral}

Realizar uma pesquisa bibliométrica sobre os métodos usados para medir o valor econômico de bibliotecas e selecionar métodos para valorar a Biblioteca do Ipea

\subsubsection{Objetivos específicos}

- Fazer levantamento sobre a dimensão econômica da sociedade da informação;

- Identificar na literatura os métodos usados para valoração econômica de bens intangíveis;

- Fazer levantamento bibliográfico sobre valoração econômica de bibliotecas;

- Elaborar um panorama dos estudos publicados sobre valoração econômica de bibliotecas;

- Fazer uma análise crítica dos métodos recomendados pela literatura;

- Propor métodos de medir o valor econômico que podem ser aplicados na Biblioteca do Ipea. 


\section{A SOCIEDADE E A ECONOMIA DA INFORMAÇÃO E DO CONHECIMENTO}

As mudanças acontecidas a partir da segunda metade do Século XX permitiram à sociedade atual uma evolução no acesso e na comunicação de recursos informacionais, devido ao desenvolvimento de tecnologias. Atualmente, o mundo inteiro está conectado de forma sistemática, de forma que as noções de espaço e de tempo foram modificadas. Essa nova realidade está inserida na sociedade de forma que já não é surpresa conseguir estabelecer contato imediato e coletivo com pessoas situadas em diversas partes do globo terrestre ou explorar um universo feito em realidade virtual. "A informação flui a velocidades e em quantidades há apenas poucos anos inimagináveis, assumindo valores sociais e econômicos fundamentais". (TAKAHASHI, 2000, p. 3)

Esse novo paradigma é objeto de estudo de muitas áreas do conhecimento, como a Economia, a Administração e a Ciência da Informação. Para representar o novo contexto mundial, foram atribuídos nomes como 'sociedade pós-industrial', 'terceira revolução industrial', 'sociedade da informação', 'sociedade do conhecimento', 'nova economia', 'economia da informação', 'economia do conhecimento', entre outros. Para simplificar o entendimento e reduzir a sinonímia de termos, serão utilizados os termos 'sociedade da informação' para referir ao contexto político-social e 'economia da informação' para referir ao contexto econômico dessa nova sociedade, incluído nos estudos de teoria econômica. A compreensão do conceito de economia da informação e do conhecimento pressupõe o entendimento de sociedade da informação, que será detalhada a seguir.

\subsection{O contexto político-social da sociedade da informação}

Os ideais e as características presentes na sociedade da informação foram construídos com a evolução da sociedade em si. A evolução da globalização criou um cenário sistêmico e colaborativo tornando o mundo no que o filósofo canadense Mcluhan (1918-1980) chamou de 'aldeia global'. Além disso, a informação sempre foi fator relevante para o desenvolvimento, desde a criação da escrita, até a criação de tecnologias como a imprensa, o telefone, o rádio, a televisão e a internet, que permitiram o aumento da produção, armazenamento e comunicação de informações. Porém, a aplicação de todos esses conceitos no contexto mundial só foi possível devido à conjuntura do final do século $\mathrm{XX}$, quando a informação e o conhecimento se tornaram claramente bens de consumo e a posse desses recursos passaram a ser sinônimo de desenvolvimento, tornando estratégica a decisão de ser 
um membro dessa sociedade global da informação. O conceito e a busca para a inclusão em uma sociedade da informação cresceu rapidamente, principalmente devido às características de compartilhamento e comunicação de informações, característicos dessa própria sociedade.

A segunda metade do século XX ficou caracterizada pelo surgimento de um novo paradigma político-econômico em ordem mundial, que inicialmente ficou conhecido como sociedade pós-industrial. Porém, nas últimas décadas essa nova sociedade ficou conhecida como 'Sociedade da Informação', devido à importância que a informação e o conhecimento passam a ter nesse novo contexto. Se, no contexto anterior, o nível de industrialização era um fator determinante para identificar a riqueza de um país, nesse novo contexto, a capacidade de produção, armazenamento e comunicação da informação passaram a ser os principais fatores indicativos de desenvolvimento de um país.

A evolução da tecnologia de informação teve uma grande importância para o desenvolvimento dessa sociedade, assim como a evolução dos setores de telecomunicação, o crescimento das redes de informação e a popularização da internet. Todos esses fatores permitiram o crescimento exponencial da produção, uso e acesso à informação, gerando assim uma 'explosão informacional', com proporções nunca vistas pela humanidade. Apesar disso, a sociedade da informação não se deve apenas a fatores tecnológicos, mas também a fatores sociais, políticos e econômicos. Castells (2000 apud WERTHEIN, 2000, p. 72) aponta que nos Estado Unidos, berço da sociedade da informação, o contexto tecnológico era favorecido politicamente pelos investimentos militares e dos mercados nos primeiros estágios da indústria eletrônica, entre as décadas de 40 e 60; e socialmente, pela cultura libertária que crescia a partir da década de 60. Takahashi afirma que

[A sociedade da informação] é um fenômeno global, com elevado potencial transformador das atividades sociais e econômicas, uma vez que a estrutura e a dinâmica dessas atividades inevitavelmente serão, em alguma medida, afetadas pela infraestrutura de informações disponível. É também acentuada sua dimensão político-econômica, decorrente da contribuição da infraestrutura de informações para que as regiões sejam mais ou menos atraentes em relação aos negócios e empreendimentos. Sua importância assemelha-se à de uma boa estrada de rodagem para o sucesso econômico das localidades. Tem ainda marcante dimensão social, em virtude do seu elevado potencial de promover a integração, ao reduzir as distâncias entre pessoas e aumentar o seu nível de informação. (TAKAHASHI, 2000, p. 5)

Werthein (2000, p. 71) afirma que a sociedade informacional está ligada à expansão e reestruturação do capitalismo desde a década de 80 do século XX e que se tornou o principal traço característico do debate público sobre o desenvolvimento seja em nível local ou global no início do século XXI. Isso se explica nas expectativas que existem diante da 
aplicação desse novo contexto, como a perspectiva de avanços significativos para a vida individual e coletiva, trazidos por recursos intensos em informação e conhecimento, gerando aprendizagem constante e incentivo à inovação.

Todos os setores podem se beneficiar com a popularização dos meios de acesso à informação, devido ao caráter estratégico que o uso das informações permite obter. Quanto ao potencial uso de informações para a sociedade, Ferreira (2003, p. 36) apresenta a finalidade da informação para os três setores econômicos: o mercado, o Estado e a sociedade civil. Segundo o autor, no mercado, as informações são utilizadas para obter vantagem competitiva, conseguida com mais captação de informações sobre produção, clientes, fornecedores e sobre o próprio mercado. Para o Estado, as informações são utilizadas para a manutenção de sua soberania e para a análise da realidade social e elaboração, aplicação e controle de políticas públicas que promovam o bem-estar da coletividade, a partir do uso de suas instituições legislativas, executivas e judiciárias. Para a sociedade civil, por sua vez, o uso das informações é voltado para fins diversos, como entretenimento, crescimento intelectual e exercício da cidadania.

Juntamente com a expectativa positiva de inclusão informacional em nível global, surgem preocupações econômicas e sociais relativas ao estabelecimento de um novo paradigma: como promover o acesso e incentivar a inclusão de todos os setores da sociedade, evitando a criação de uma população de excluídos informacionais? De fato, o acesso à informação traz novos conceitos de inclusão e exclusão social, baseado até mesmo em um novo conceito de cidadania, que traz o acesso à informação como uma necessidade básica. Com o intuito de solucionar essas questões, minimizar os impactos negativos, diminuir os entraves e assim promover o desenvolvimento da sociedade da informação, foram criadas iniciativas específicas para os países e seus respectivos blocos econômicos. Partindo dessa perspectiva em que o paradigma pós-industrial imprime uma nova dinâmica à sociedade, ao Estado e aos agentes econômicos, vários países de diferentes realidades tecnológicas, políticas, sociais e culturais fizeram esforços para se adaptarem ao novo contexto. (FERREIRA, 2003, p. 37)

\subsubsection{Iniciativas para a sociedade global da informação}

A noção de uma sociedade global da informação é uma construção de natureza político-econômica iniciada em meados dos anos 1990, a partir da discussão entre vários países sobre o estabelecimento de um novo cenário em nível mundial, com base no uso de 
tecnologias de informação. Takahashi (2000, p. 108) afirma que a motivação das primeiras iniciativas nacionais foram explicitamente econômicas ou industriais com forte viés econômico.

A primeira iniciativa da sociedade global da informação foi feita pelos Estados Unidos da América (EUA), com lançamento do Programa HPCC (High Performance Computing and Communications), que pode ser considerado o começo do processo que hoje perpassa governos e empresas sob o rótulo de sociedade da informação, e da NII (National Information Infrastructure) americana e, posteriormente, da GII (Global Information Infrastructure). A primazia americana se deve ao contexto de liderança na internet e de investimento em alta-tecnologia depois da guerra fria. Depois dos EUA, a União Europeia investiu na informatização interna dos países, sobretudo na administração pública, e tomou iniciativas em relação às indústrias e ao setor de telecomunicações. Outros países como a Austrália e o Canadá tomaram iniciativas próprias, complementadas por grupos de cooperação internacional, como G7 e OCDE. (TAKAHASHI, 2000, p. 107)

O estabelecimento dessa sociedade global da informação não dependia apenas da criação de uma infraestrutura tecnológica. Cada país seria responsável por tratar de questões internas de várias naturezas, como questões legais, econômicas e sociais, que criariam um contexto interno propício à inclusão no contexto mundial. Além disso, a cooperação entre países se tornava uma questão essencial, por permitir relacionamentos políticos e econômicos. O investimento interno em pesquisa e desenvolvimento também se fazia necessário para a criação da sociedade da informação. Sobre as estratégias de aplicação dos programas com vistas à sociedade da informação no mundo, Takahashi diz:

Em uma frase, no caso dos EUA, o esforço foi estruturado, na origem, como um megaprograma de pesquisa dentro do qual se inseriu um componente de articulação de aplicações e de difusão para o setor privado/governamental. Já no caso da União Européia, a iniciativa foi estruturada, na origem, como um megaprograma de ações políticas (de várias naturezas, desde indução de aplicações até estímulo à privatização de telecomunicações) dentro do qual há um componente de $\mathrm{P} \& \mathrm{D}$ e de infraestrutura de redes para educação e pesquisa. (TAKAHASHI, 2000, p. 110)

Com a expansão da Internet, com o uso constante das tecnologias e com a pressão internacional, o governo brasileiro sentiu necessidade de elaborar políticas públicas que pudessem prevenir e pensar o uso da rede de forma a não estimular a exclusão digital. (SANTOS; CARVALHO, 2009, p. 45)

O projeto de inclusão informacional para o desenvolvimento, denominado 'Sociedade da informação no Brasil', foi apresentado à sociedade pelo Ministério da Ciência e 
Tecnologia, no denominado Livro Verde, e sugeria a participação do Estado na construção de uma infraestrutura capaz para integrar e coordenar o desenvolvimento e a utilização de serviços avançados de computação, comunicação e informação e de suas aplicações na sociedade. A execução do programa pressupunha o compartilhamento de responsabilidades entre os três setores: governo, iniciativa privada e sociedade civil. O propósito dessa iniciativa era integrar, coordenar e fomentar ações para a utilização de tecnologias de informação e comunicação, de forma a contribuir para a inclusão social de todos os brasileiros na nova sociedade e, ao mesmo tempo, contribuir para que a economia do país tenha condições de competir no mercado mundial. (TAKAHASHI, 2000, p. 10)

Em uma avaliação posterior, Santos e Carvalho (2009, p. 47) afirmam que o Programa Sociedade da Informação no Brasil apresentou falta de solidez, profundidade e subsídios científicos nas discussões para concepção do Livro Verde e trata a questão como sendo meramente tecnológica. As autoras também afirmam que a mudança de governo em 2002 culminou com a mudança de foco do programa, priorizando projetos que valorizavam a inclusão digital e a conectividade. A mudança de escopo do programa se deve a algo previsto por Ferreira (2003, p 40) quando disse que questões políticas deveriam ser sanadas, pois a consolidação de uma sociedade da informação sem a inclusão social adequada não teria os efeitos benéficos previstos para o Estado e para a sociedade civil. Porém, os novos projetos de inclusão do novo governo estavam preocupados, sobretudo na promoção do acesso, mas não no letramento informacional da população, de forma que o potencial cognitivo dos cidadãos conectados não era valorizado. (SANTOS; CARVALHO, 2009, p. 53)

A sociedade da Informação não é apenas um conceito teórico. Trate-se da realidade atual que abrange e afeta a todos os indivíduos. Os governos dos diferentes países tem trabalhado ao longo das duas últimas décadas para a adequação de suas instituições a essa nova sociedade global. O Programa Sociedade da Informação no Brasil é apenas um exemplo de aplicação desse conceito nos países. Assim como o Brasil, vários países se encontram em estágios distintos de implementação de meios para promover e regulamentar as questões relativas à sociedade da informação. Essas iniciativas de inserção na nova sociedade não partem apenas do governo, mas também do setor privado e da sociedade civil.

\subsection{A abordagem macroeconômica da sociedade da informação}

As primeiras concepções econômicas de uma sociedade pós-industrial que observaram o crescimento de setores diferentes da agricultura e da indústria apareceram no 
final dos anos 1950, mas a descrição fundamental da nova economia surgiu com Machlup (1962 apud Verzola, 2005), que usou o termo 'indústria baseada em conhecimento', e com Porat (1977 apud Verzola, 2005), que usou o termo 'economia da informação' para denominar o novo setor emergente. Verzola (2005) ainda afirma que, para Porat (1977), existem dois domínios da economia: o domínio da matéria e da energia e o domínio da informação.

O período analisado por Machlup e Porat diz respeito à transição do crescimento fordista que vinha sendo difundido no pós-guerra para uma economia e que segundo Tigre (2005, p.75) representa um marco da onda Schumpeteriana de destruição criadora, destacando três acontecimentos: o primeiro foi a crise do petróleo dos anos 1970, que mostrou ao mundo a insustentabilidade de um modelo crescente de consumo de materiais e energia barata; o segundo, foi o esgotamento do modelo fordista de produção, baseado na exploração excessiva dos princípios de padronização e divisão do trabalho; e o terceiro, e mais importante, foi a onda de inovações iniciada com a evolução da tecnologia de informação e comunicação (TICs).

Tigre (2005, p. 76) afirma também que, para as empresas e organizações, a principal consequência da difusão das TICs foi a abertura para "inovações organizacionais caracterizada pelo desenvolvimento de modelos de gestão mais intensivos em informação e conhecimento". A possibilidade de integrar cadeias globais de suprimento, aproximar fornecedores de usuários e acessar informações online em multimídia alimenta o desenvolvimento de uma nova infraestrutura, novos modelos de negócio e de inovações organizacionais que sejam impensáveis sem informação e a comunicação. As TICs tem um papel fundamental na redução de espaços econômicos privilegiados alcançados com a globalização e a liberação dos mercados.

\subsubsection{A informação e o conhecimento na nova economia}

Tigre (2005, p. 76) diferencia os termos 'economia da informação' e 'economia do conhecimento'. Segundo ele, a economia do conhecimento seria um conceito mais abrangente onde o conhecimento se torna um insumo mais importante para o processo produtivo, mesmo diante do capital, do trabalho e da terra. Uma economia baseada em conhecimento se apoia na habilidade de gerar, armazenar, recuperar, processar e transmitir informações. A economia da informação tende a considerar a informação como um produto em si, de forma codificada ou embutida em outros produtos e serviços. A principal diferença 
entre os dois conceitos seria o fato de que o segundo seria aplicado apenas na indústria de informação.

Essas definições, porém, não tratam de consenso na literatura e, tendo em vista que a informação é o bem intangível registrado que pode ser comercializado, escolheu-se utilizar o termo 'economia da informação' para representar esse conceito. As funções e usos de informações e conhecimentos na economia da informação ficam claros no texto de Takahashi:

\begin{abstract}
Através das redes eletrônicas que interconectam as empresas em vários pontos do planeta, trafega a principal matéria-prima desse novo paradigma: a informação. A capacidade de gerar, tratar e transmitir informação é a primeira etapa de uma cadeia de produção que se completa com sua aplicação no processo de agregação de valor a produtos e serviços. Nesse contexto, impõe-se, para empresas e trabalhadores, o desafio de adquirir a competência necessária para transformar informação em um recurso econômico estratégico, ou seja, o conhecimento.

O conhecimento é hoje fator essencial em todas as etapas do processo produtivo, desde a pesquisa básica até o marketing final e assistência ao consumidor. Mas é na fase inicial de projeto e concepção de produtos e serviços que esse fator é mais crítico. Essa etapa requer o domínio de tecnologias-chave, vultosos investimentos em pesquisa, ambiente institucional favorável e pessoas altamente capacitadas, fatores das economias avançadas. Relativamente, as fases subseqüientes do processo são menos intensivas em conhecimento e podem ser desenvolvidas em um grande número de países. (TAKAHASHI, 2000, p. 17)
\end{abstract}

Ainda sobre a relação entre informação e conhecimento nesse contexto, Marcondes (2001, p. 61) salienta a necessidade de organização da informação, para que o conhecimento registrado se torne recuperável.

Na emergência da sociedade da informação, o valor desta como insumo para qualquer atividade, seja ela uma decisão econômica, um processo cultural ou de ensino/aprendizagem, uma pesquisa científica ou tecnológica, está relacionado diretamente ao seu potencial de orientar de forma econômica $o$ dispêndio de energia para a realização desta atividade. Para que possa realizar todo este potencial, a informação relevante para um dado problema precisa estar disponível no tempo certo. De nada adianta a informação existir, se quem dela necessita não sabe da sua existência, ou se ela não puder ser encontrada. [...] Localizar/identificar informações é uma etapa fundamental na economia da informação e do conhecimento.

\title{
2.2.2 O setor de informação
}

Na economia da informação, o setor de informações se torna predominante diante da agricultura e da indústria. O setor de informações, segundo Verzola (2005) é a parte da economia que lida com a criação, manipulação, processamento, transmissão, distribuição e 
uso de informações, sendo que a informação é uma entidade não-material e não-energética, que toma forma física apenas quando armazenada em meio físico (como em um disco rígido) ou comunicada de forma física (como em um sinal de rádio).

A informação como bem de consumo possui propriedades diferentes de bens físicos, pois o consumo, o valor e a utilidade de bens informacionais funcionam com outra lógica. A maior parte dos custos relacionados ao setor de informação diz respeito a recursos humanos e tecnológicos. À medida que a tecnologia da informação avança, as formas de armazenar as informações e a comunicação que utilizam menos matéria e menos energia continuam a ser desenvolvidas, diminuindo, assim, o custo de reprodução da informação. Essa lógica é diferente dos setores de produção de bens físicos que contêm em cada unidade uma quantidade fixa de matéria e energia consumidas e cujo preço reflete o custo de produção. Os bens informativos podem ser reproduzidos a um custo de produção marginal perto de zero, permitindo que, uma vez criado, sua escassez possa ser interrompida praticamente sem custo algum. Assim, o estudo da economia de informação deve envolver não apenas um estudo convencional da economia da escassez, mas também da economia da abundância. (VERZOLA, 2005)

Cohen (2010, p. 41) enfatiza a redução de custos que a informação proporciona em todo processo produtivo e em toda a cadeia de valor. Shapiro e Varian (1999 apud, COHEN, 2010, p. 45) afirmam que, na economia da informação, os bens informacionais possuem um custo alto de produção, mas baixos custos para reprodução, implicando alto custo fixo e baixo custo marginal, sugerindo assim que se deve fixar o custo da informação de acordo com seu valor e não com seu custo.

A economia da informação não diz respeito apenas à informação como recurso intangível, mas a todo o universo que compreende o ciclo informacional. Assim, são incluídos os recursos humanos empregados na produção, no tratamento e na disseminação de informações; são incluídos os equipamentos e instalações utilizados em todo o ciclo informacional (como computadores, estúdios, redes, bibliotecas, arquivos etc.); e também são incluídos os suportes onde as informações são armazenadas e disponibilizadas para consumo (como softwares, livros, páginas de internet etc.). (VERZOLA, 2005)

Atualmente, qualquer bem de consumo costuma ser resultado de um processo com uso intenso de informações e conhecimento. Devido à necessidade de se manter competitiva e atender mercados cada vez mais específicos, as empresas investem em gastos com informações. Desta forma, ao adquirir um produto (seja um medicamento, um cosmético ou 
até mesmo um utensílio doméstico) estão incluídos no preço o valor do investimento em pesquisa e inovação que as empresas fazem.

$\mathrm{O}$ alto investimento em recursos ligados à informação favorece a criação de mercados específicos totalmente voltados à informação e ao conhecimento. Assim surgiu o termo 'trabalhadores do conhecimento', que Drucker (MACEDO et al., 2015, p.147) utilizou para definir as pessoas que tratam de qualquer parte do ciclo informacional, seja planejamento, obtenção, busca, análise, organização, armazenamento, programação, distribuição, marketing ou outra forma de trabalho que contribui para a transformação ou o comércio de informações. Entre esses trabalhadores do conhecimento, são incluídos também os acadêmicos, os pesquisadores, os bibliotecários e cientistas da informação.

Sobre o perfil dos trabalhadores, Takahashi (2000, p. 21) afirma que novas especializações profissionais e postos de trabalho surgiram, mas também diversas ocupações tradicionais foram transformadas, substituídas ou mesmo eliminadas. O autor ainda diz que cada vez mais se exige dos trabalhadores contínua atualização e desenvolvimento de habilidades e competências, a fim de atender aos novos requisitos técnico-econômicos e a aumentar sua empregabilidade.

Além do investimento em produtos intensos em informação e conhecimento, a lógica de negócios mudou para todas as empresas. A administração baseada em bens tangíveis não é mais tão adequada a esse contexto, quanto foi na era industrial. Atualmente, o valor das empresas é baseado, sobretudo, nos bens intangíveis. Ao tratar do novo contexto econômico que as empresas enfrentam atualmente, Valle (2016) aponta cinco princípios que resumem a lógica da participação das empresas no mercado da economia da informação: 1 - o conhecimento é um ativo central para geração de valor nos negócios; 2 - o conhecimento é um fenômeno não apenas individual, mas também organizacional e ecossistêmico; 3 - o intercâmbio de intangíveis entre organizações é tão importante quanto as trocas transacionais de bens tangíveis; 4 - o conhecimento só gera valor quando aplicado; e 5 - o conhecimento é um elemento-chave da cidadania.

Os princípios de Valle (2016) enfatizam a necessidade e as dificuldades de gestão de ativos intangíveis dentro das organizações, sobretudo a gestão do conhecimento como ativo intangível. No primeiro princípio, autor fala da gestão de bens tangíveis nas organizações e sobre a evolução para gestão de bens intangíveis, como a marca de uma empresa, mas salienta que o conhecimento "é parte indissociável de todo produto, processo ou decisão de um negócio, de todo relacionamento e de toda ação de uma organização”. Assim, até mesmo os bens tangíveis são resultados de investimentos em informação e conhecimento 
e, muitas vezes, recursos físicos precisam de conhecimentos especializados para serem manejados dentro das organizações.

No segundo princípio, encontra-se a percepção da organização como o resultado de vários fluxos de conhecimento entre indivíduos, organizações e o mercado. O investimento em desenvolvimento de pessoal não seria suficiente para conseguir uma adequada gestão de conhecimentos, mas seria necessário compreender o contexto complexo organizacional, que inclui cadeias produtivas, setores e mercados, formando o que o autor chama de 'ecossistemas mercadológicos'. Além da qualificação pessoal do indivíduo, esses ecossistemas exigem uma “complexa combinação de regras, fluxos de informação, formas de organização e dinâmicas de atuação que não são dominadas por nenhum indivíduo isolado, mas sim configuram um conhecimento interorganizacional complexo". (VALLE, 2016)

O terceiro princípio enfatiza a 'comercialização' de bens intangíveis. Normalmente, as organizações estão acostumadas a fazer transações comerciais com bens tangíveis, trocando produtos e serviços por dinheiro, mas parte relevante dos negócios tratam de relacionamentos de conhecimento e participação. Os relacionamentos e interações baseadas em conhecimento e colaboração permitem a "formatação, segmentação e customização de produtos e serviços, a estruturação de propostas comerciais, a formação de parcerias de confiança e muitos outros elementos da geração de valor.” (VALLE, 2016)

O quarto princípio incentiva a aplicação do conhecimento dentro da organização e critica as iniciativas que se baseiam apenas na disseminação de conhecimento para captação entre funcionários. $\mathrm{O}$ autor afirma que o valor do conhecimento potencial somente passa a ser real quando ele é empregado na prática do negócio, gerando resultados. Assim, as organizações devem investir na fusão entre a aprendizagem e a aplicação do conhecimento, a fim de gerar valor e resultar em inovações.

No quinto princípio, observa-se a função social do conhecimento enquanto bem intangível não-escasso, abrindo um grande potencial transformador e beneficiando tanto as empresas e organizações quanto a sociedade como um todo.

\subsection{A abordagem microeconômica da sociedade da informação}

Os conceitos de sociedade da informação interferiram também no desenvolvimento da teoria econômica. Com a crescente importância dada à informação em todos os setores da sociedade, inclusive no mercado, o conceito de economia da informação dentro do estudo da teoria econômica ganhou força, sobretudo nos anos 1970, com a 
publicação dos trabalhos de Joseph Stiglitz, George Akerlof e Michael Spence, criadores do conceito de 'assimetria de informação' aplicado na teoria geral dos mercados. A assimetria da informação representava o descobrimento de uma nova falha de mercado. A contribuição desses autores foi reconhecida com o recebimento do Prêmio Nobel de Economia em 2001.

Stiglitz (2002, apud CEOLIN, 2011, p. 29) afirma que a economia da informação não representa um campo novo de especialização da economia (como a economia do trabalho, economia monetária e economia ambiental), mas indica que as informações devem ser consideradas, de fato, um aspecto central na análise de uma série de fenômenos e que ela se constitui em uma parte central dos fundamentos da análise econômica.

Akerlof (1970) diz que a abordagem da economia da informação tem relação com a economia neoclássica, referente à disponibilidade da informação nos mercados, ao equilíbrio em função da interação entre oferta e demanda, a fim de aumentar a eficiência e diminuir os custos. Porém, ao invés de pressupor fluxo perfeito de informações, como era comum entre os neoclássicos, a economia da informação parte do principio que os agentes têm acessos a diferentes informações durante uma ação econômica.

\subsubsection{Os mercados imperfeitos}

Em um mercado de competição perfeita todos os bens de troca equivalentes possuem o mesmo valor, todos os grupos possuem a mesma organização e todos os indivíduos possuem a mesma chance de sobrevivência. Porém, isso não existe, sobretudo, por conta de falhas de mercado, causadas por fatores como a competição imperfeita, as externalidades e a assimetria de informações (TAGNIN, 2004, p.32)

As externalidades geram falhas de mercado quando um agente econômico afeta o bem-estar de outros agentes, positivamente ou negativamente, de forma que essas ações não resultem em alterações nos preços de mercado. (TAGNIN, 2004, p.41)

Quanto à competição nos mercados, Tagnin (2004, p. 33) afirma que para que um mercado seja completamente perfeito, as empresa são formadoras de preços e produzem uma quantidade de bens ao qual o custo marginal se iguala ao preço e assim, a oferta do conjunto de firmas que compõem a indústria pode ser determinada agregando-se as curvas de custo marginal das empresas individuais compondo um quadro em que as empresas assumem lucro econômico zero pelo longo prazo. A teoria da competição perfeita, segundo o autor, baseia-se em quatro suposições, conforme pode ser visto a seguir. 
A primeira é a aceitação de preços, onde cada empresa comercializa apenas uma quantidade pequena de bens em relação ao total produzido pela indústria, de modo que qualquer decisão que tomar não influencia o preço do bem no mercado. Dessa maneira, cada firma assume o preço do mercado. Da mesma forma cada consumidor compra apenas uma pequena quantidade desses bens não influenciando, por sua vez, o preço do bem e adotando-os como dado.

A segunda suposição é de que todas as empresas produzem produtos idênticos, de modo que os consumidores consideram apenas o preço quando escolhe de quem não comprar os bens. Nessa situação, qualquer empresa que aumente seus preços acima do preço de mercado terá suas vendas reduzidas a zero.

A terceira suposição é a de que haverá uma perfeita mobilidade de recursos e as empresas podem entrar e sair da indústria a qualquer momento, sem enfrentar barreiras e sem incorrer em custos de realocação de recursos de produção.

Finalmente, supõe-se que informação é perfeita, o que significa que os consumidores têm todas as informações sobre suas preferências, níveis de venda, preços e qualidade dos bens que adquirem. Analogamente as empresas possuem informações perfeitas sobre seus custos, preços e tecnologias. (TAGNIN, 2004, p.33)

Essas suposições, porém, não acontecem na realidade dos mercados. Não existe aceitação de preços, pois cada empresa produz de acordo com seus custos e estimativas de demandas e os preços de seus produtos refletem o custo de oportunidade de obtenção desses bens e, além disso, grandes empresas com expressivo poder de mercado podem manter os preços acima do equilíbrio de mercado e vender por preços acima do custo marginal por longos prazos, como acontece em monopólios e oligopólios. As empresas não produzem bens idênticos, pois cada empresa possui recursos humanos e materiais diferentes e procuram diferenciação dos produtos, como recurso estratégico. Não existe perfeita mobilidade de recursos para que uma empresa possa sair e entrar em qualquer mercado sem incorrer em custos de realocação de recursos, sem enfrentar barreiras de entrada em outros mercados e sem iniciar suas atividades sem poder de barganha em relação a fornecedores e clientes. Finalmente, não existe mercado com informações simétricas, pois as pessoas e empresas não conhecem as informações pessoais e de qualidade de produtos e serviços que recebem.

\subsubsection{Assimetria de informação}

Assimetria da informação é o nome que se dá à diferença de acesso à informação entre as partes de uma transação. Isso acontece quando uma das partes tem acesso privado a determinada informação ou, caso se trate de informação pública, quando a capacidade de acesso é diferente entre as partes dessa transação. A parte mais bem informada tem a 
possibilidade de explorar essa vantagem em benefício próprio, enquanto a parte menos informada age com cautela, ciente de seu estado latente de informação. O comportamento entre as partes quanto ao acesso à informação influencia diretamente no resultado da transação, levando frequentemente a um resultado subótimo. (RENK, 2009, p.9)

Diante da existência de um acordo, formal ou não, entre as partes, genericamente chamado de contrato, é possível definir se os problemas de informação acontecem antes do contrato, gerando uma seleção adversa, ou depois do contrato, gerando risco moral. A seguir serão apresentados os problemas informacionais, juntamente com seus devidos mecanismos de controle.

\subsubsection{Seleção adversa}

Akerlof (1970) apresenta o primeiro conceito de informação assimétrica a partir da apresentação do mercado de carros usados, o qual chamou de "market for lemons". Nesse mercado, o consumidor não possui a mesma informação que o vendedor quanto ao estado de conservação e funcionamento dos carros que estão sendo vendidos. Em geral, o consumidor só teria consciência do estado do carro após a venda, aumentando a desconfiança quanto ao produto e reduzindo sua inclinação a pagar valores mais altos. Com o cliente disposto a pagar menos, o vendedor não se sente motivado a colocar carros de melhor qualidade à venda, pois o baixo preço de aquisição não faria o negócio valer a pena. Assim, o mercado de carros usados seria predominantemente ocupado por carros em estado ruim. Quando há informação assimétrica, as trocas desejáveis deixam de existir e o mercado fica prejudicado. Esse fenômeno ficou conhecido como seleção adversa.

A seleção adversa ocorre também em outros mercados com informação assimétrica, como, por exemplo, os mercados de planos de saúde, seguros de carro e crédito. No mercado de plano de saúde, as seguradoras não têm informação suficiente sobre o estado de saúde do consumidor antes de realizar o contrato, fazendo com que o preço médio dos planos seja mais alto e, consequentemente, provocando a seleção adversa por meio da inibição de pessoas jovens e saudáveis e incentivando a presença de pessoas idosas e doentes. No mercado de seguros de automóveis, as empresas cobram um valor médio baseado em fatores comuns a motoristas que estão mais propensos a estarem envolvidos em acidentes e, assim, inibe a participação de motoristas cautelosos e prudentes. No mercado de crédito, os bancos cobram juros altos para compensar a falta de informação quanto à possibilidade de inadimplência dos clientes e, assim, prejudica os clientes que pagam em dia suas dívidas. Em 
todos esses casos, as relações comerciais foram prejudicadas, por fornecerem prejuízo ao vendedor ou ao cliente.

Em um mercado onde existe seleção adversa, todos os agentes são prejudicados. Sobre as consequências da seleção adversa nos agentes econômicos, Renck (2009, p. 19) afirma:

Em grandes linhas, diante da existência de seleção adversa em um mercado, os primeiros afetados são os agentes com o perfil mais desejável (serviços de alta qualidade, baixo risco de crédito, boas condições de saúde, etc.), pois não têm opção senão adentrar o mercado sem distinguir-se dos indivíduos indesejáveis e, assim, pagando mais (caso sejam compradores) ou recebendo menos (caso sejam vendedores) do que o real valor dos bens transacionados. O segundo grupo afetado é composto pelos agentes hipoinformados e que, por isto, precisam empregar instrumentos de seleção. Um ambiente em que não é possível distinguir facilmente os agentes oferece incentivos para que indivíduos com perfis indesejáveis procurem espaço; se houvesse tal facilidade, estes seriam rapidamente identificados e excluídos do mercado. Porque é caro - e, em certos casos, mesmo impossível - se obter informações precisas acerca dos agentes, aumentam as chances de um indivíduo de perfil indesejável passar incólume pelos processos seletivos. Consequentemente, naqueles mercados em que o perfil dos agentes é difícil de distinguir é onde a proporção de indivíduos com perfil indesejável é maior, o que aumentam ainda mais os custos de seleção. Mais a este respeito será apresentado quando da aplicação do mecanismo de filtragem à concessão de crédito.

Em terceiro lugar, e como consequência dos dois efeitos anteriores, a ocorrência de seleção adversa pode prejudicar mesmo os indivíduos indesejáveis que se beneficiam da dificuldade de distinção entre os agentes (serviços de baixa qualidade, devedores com alto risco de crédito, indivíduos em más condições de saúde, etc.). Isto se dá porque a seleção adversa pode levar ao colapso do mercado, impedindo mesmo estes indivíduos de acessar os bens desejados.

Spence (1973 apud RENCK, 2009, p. 29) apresenta o conceito de sinalização, como um mecanismo dedicado a diminuir a seleção adversa, criado pelo próprio mercado, a fim de que a parte mais bem informada informe à outra parte todas as suas intenções e características, de forma crível. Isso é o exemplo do contrato de garantia, com o qual o vendedor pode cobrar preço elevado com a garantia de que o produto tem qualidade e vai cumprir tudo o que foi assegurado. Isso resolve, por exemplo, o problema de aquisição de carros usados.

Outra solução para a seleção adversa, apresentada por Molho (1997 apud RENCK, 2009, p. 30), consiste na filtragem. Nesse mecanismo, um dos agentes cria produtos ou contratos para atrair somente uma selecionada parte dos clientes em potencial, através da montagem de grupos de clientes, separados por características comportamentais. Diferentemente da sinalização, onde os agentes fornecem suas próprias informações, na 
filtragem, os agentes buscam conseguir informações a respeito do comportamento dos outros agentes presentes no contrato.

\subsubsection{Risco moral}

A existência de um contrato por si só não extingue as assimetrias informacionais, mesmo que as partes tenham contornado a carência informacional na fase pré-contrato. Isso pode acontecer de duas formas: a primeira, diz respeito às necessidades informacionais que surgem durante a execução do contrato e que podem não estar disponíveis igualmente entre os agentes; a segunda diz respeito à possibilidade de não haver alinhamento completo de interesses ou se o contrato não previr todas as possibilidades de acontecimentos, uma das partes pode tentar usar essa falha em benefício próprio. (RENCK, 2009, p. 23)

Stiglitz (2002 apud RENCK, 2009, p. 23) apresenta o conceito de risco moral, que, diferentemente da seleção adversa, representa uma falha de mercado que pode acontecer após a assinatura de contratos. O risco moral se refere à situação onde um agente não pode observar, monitorar ou influenciar as ações de outros agentes do mercado, de modo que esses agentes podem se beneficiar de falhas relativas ao contrato que assinaram ou podem passar a ter comportamentos diferentes do esperado, como o caso de clientes devedores. Nas palavras de Renck (2009, p. 23), na fase pós-contratual existe o risco que uma das partes, diante da possibilidade de agir ocultamente, ignore sua responsabilidade moral intrínseca pelo cumprimento do contrato e gere danos às demais partes.

Uma solução para o risco moral seria o acompanhamento e fiscalização das ações da outra parte do contrato, a fim de identificar possíveis descumprimentos do contrato. Essa solução se chama monitoramento e, segundo Milgrom e Roberts (1992, apud TAGNIN, 2004, p. 38), requer o desenvolvimento de fontes de informação sobre o desempenho e confiabilidade de um agente ou, uma solução com menor custo, seria se apoiar na competitividade de agentes com interesses conflitantes para gerarem as informações necessárias.

Outra solução para o problema do risco moral é a possibilidade de um agente responder pelo descumprimento de contrato ou mudança no padrão de comportamento. Isso permitiria que uma seguradora de veículos cobrasse mais caro, caso o cliente se mostrasse negligente ou que uma empresa condicionasse o pagamento de salário e a participação nos lucros ao resultado apresentado pelo empregado. Esse mecanismo se chama medidas de compromisso. (RENCK, 2009, p. 35) 


\subsubsection{A assimetria de informação e os custos de transação}

Williamson (1979 apud TAGNIN, 2004, p. 34) enfatiza que a falta de simetria de informações entre os agentes econômicos tem algumas consequências relacionadas aos custos de transação. Mathiesen (2002 apud TAGNIN, 2004, p. 37) apresenta os custos econômicos como o resultado da soma do custo de produção (relacionado diretamente à fabricação de bens ou prestação de serviços) e custo de transação. A teoria dos custos de transação é sustentada por duas características da raça humana: a racionalidade limitada dos indivíduos como agentes econômicos e o oportunismo presente nas ações desses agentes, derivado da presença de informações assimétricas. Ambas características estão relacionadas às informações aos quais os indivíduos têm acesso. Os custos de transação englobam as despesas indiretas de produção, os custos de motivação (como motivar agentes a alinhar seus interesses, custos de traição ou comportamentos oportunistas etc.) e os custos de coordenação (como coordenar ações entre os agentes, recuperar informações uteis e gerenciar o negócio). (MATHIESEN, 2002 apud TAGNIN, 2004, p. 37)

Williamson (1979 apud TAGNIN, 2004, p. 36) defende que a racionalidade dos agentes é limitada, pois o individuo toma decisões sobre um conjunto finito de variáveis, em um processo racional, mas limitado ao agregado de informações que possui, sem levar em conta o universo informacional complementar. A ideia de que a racionalidade do individuo é transferida para o processo é defendida por Fagundes (1997 apud TAGNIN, 2004, p. 36). Assim, apesar de toda a limitação dos agentes em formular e resolver problemas e no processamento e recuperação de informações, os agentes permanecem intencionalmente racionais (SIMON, 1959 apud TAGNIN, 2004, p. 36).

A limitação da racionalidade, segundo Tagnin (2004, p. 37) implica na construção de contratos incompletos, que seria a forma mais eficiente de lidar com as diferenças informacionais entre os agentes. Porém, a solução eficiente e equilibrada de transação entre os agentes esbarra em outra característica humana: o oportunismo, que é definido por Williamson (1985 apud TAGNIN, 2004, p. 37) como a busca do interesse individual com malícia, decorrente das assimetrias de informação. Esse oportunismo característico das relações humanas é o principal responsável pela seleção adversa e pelo risco moral, sendo que, no primeiro caso, o agente tem a oportunidade de agir antes do contrato e, no segundo caso, o agente age depois da assinatura do contrato. 


\subsection{Características dos bens de informação}

Andrade (2001, p. 19) disse que determinadas características intrínsecas dos bens de informação definem uma série de leituras específicas das leis econômicas, que são diferentes de outros tipos de produtos. A informação permeia as atividades do mundo físico e está presente em todos os produtos e serviços, pois um produto é o resultado de um processo intenso em conhecimento. Assim, o valor financeiro dos produtos não leva apenas em consideração o preço dos materiais físicos que os compõem, mas leva em consideração vários bens intangíveis, inclusive a informação e conhecimento desenvolvido em todo o processo de produção. O autor salienta também que as tecnologias de informação, por meio de recursos como a própria internet, permitem a separação entre o produto e a informação em si, transferindo o valor do produto ou serviço para o conjunto de informações no seu entorno.

Conforme foi dito por Verzola (2005), a informação é um bem que com elevado custo para ser produzido, mas com baixos custos para ser reproduzido. Economicamente, isso se traduz em custo fixo alto para produzir um bem de informação e custo marginal baixo para reproduzi-lo. Isso se exemplifica na gravação de um $\mathrm{CD}$, na edição de um livro e publicação de um artigo. A informação é resultado do trabalho de recursos humanos e a produção não pode ser feita em grandes quantidades. Porém, o custo de copiar e disseminar essas informações é muito baixo e chega a ser quase nulo, por causa da evolução e difusão das tecnologias de informação e comunicação.

Andrade (2001, p. 20) disse que o preço estipulado para bens informacionais não deve levar em consideração o valor da reprodução, já que é praticamente nulo, mas deve considerar o valor que o cliente está disposto a pagar por ele. $\mathrm{O}$ autor difere bens de informação comuns (como livros, CDs e DVDs) dos mais sofisticados (como obras raras). O valor dos primeiros é definido pela oferta e demanda. $\mathrm{O}$ valor do segundo é definido pelas características intrínsecas do próprio produto. O autor salienta ainda a dificuldade relacionada às copias não autorizadas, que, a seu ver, devem ser controladas por leis de direito autoral e regulamentação.

Com a criação de conteúdo facilitada pelas TICs, a sociedade atual vive um grande excesso informacional. A quantidade de conteúdo criado e compartilhado todos os dias é muito superior à capacidade humana de pesquisar e ler. Além disso, a livre publicação diminuiu a confiabilidade das informações compartilhadas. Vale ressaltar, que as iniciativas que existem, sobretudo no meio acadêmico da América Latina, de acesso aberto à informação científica visa a amenizar esse problema, mas a grande maioria das organizações ainda 
cobram para prover acesso a informações. Assim, muitas organizações utilizam a internet como suporte para venda de seus produtos informacionais, por meio de portais de notícias, streaming de áudio e vídeo, bases de dados bibliográficas etc.

Baseado na capacidade de desenvolvimento e facilidades criadas pelas TICs, Andrade (2001, p. 21) afirma que "a internet pode eliminar ou no mínimo diminuir as assimetrias de informação ao transformar o trade-off entre riqueza e abrangência da informação". O autor afirma que, na economia da informação antes da internet, era necessário escolher entre a riqueza da informação, que representa a quantidade e a especialização da informação em determinado perídio de tempo; e a abrangência, que representa a quantidade de pessoas que são atingidas pela informação, em determinado período de tempo. Porém, a internet permitiu a possibilidade de aumentar a abrangência e a personalização das informações ao mesmo tempo em que aumenta a quantidade de pessoas que são atingidas por ela.

Se por um lado a grande quantidade de informação traz benefícios como o citado no parágrafo anterior, o excesso de informação traz dificuldades de recuperação de informações úteis e exige maior quantidade de tempo dos indivíduos que realizarem essa busca. $\mathrm{O}$ excesso de informação disponível atualmente deriva um novo conceito denominado 'economia da atenção'. Esse conceito trata da limitação humana de consumir produtos informacionais, diante da grande quantidade de bens informacionais que estão disponíveis. Diante disso, cresce a necessidade de existirem serviços personalizados de informação, que sejam efetivos e rápidos. A busca por informações úteis exige um conhecimento especializado de fontes e recursos de busca. Atualmente alguns mecanismos de busca trabalham na tentativa de personalizar resultados, mas seu alcance é limitado ao perfil do usuário gerado automaticamente e ao conteúdo que está disponível para acesso público na internet. Assim, para ter acesso a informações confiáveis, o usuário precisa ter em mãos ferramentas que permitam ter acesso a informações que estão em bases pagas ou que estão impressas. Para isso, os serviços prestados por bibliotecas e unidades de informação são essenciais para diminuir a distância entre o usuário e sua informação desejada. 


\section{MÉTODOS DE VALORAÇÃO DE BENS INTANGÍVEIS}

$\mathrm{Na}$ economia industrial a valoração de bens era relativamente simples, pois a avaliação de preços era baseada no custo de produção de bens tangíveis. Da mesma forma, a valoração de uma empresa era considerada a partir da avaliação de seus bens tangíveis. Nesse contexto, o meio ambiente era considerado um bem infinito e a informação não havia sido percebida como fator decisivo de desenvolvimento.

$\mathrm{Na}$ atualidade, a quantidade de bens tangíveis está cada vez menos relevante para avaliar o preço de uma organização. Isso se deve principalmente às oportunidades e facilidades de negócio geradas pelas tecnologias de informação. Conforme foi apresentado no capítulo anterior, o preço de um produto não é resultado apenas da soma do valor de mercado dos bens tangíveis que foram usados em sua produção. O preço leva em consideração uma série de bens intangíveis, que inclui, entre outros, a aceitabilidade da marca no mercado e a informação e o conhecimento utilizados em seu processo de produção. Da mesma forma, o valor de mercado de grandes empresas já não está mais relacionado a bens tangíveis. Atualmente, destacam-se no mercado empresas como o Airbnb, o Uber e o Facebook, que possuem valores altos no mercado, embora seus investimentos sejam quase totalmente baseados em bens intangíveis.

Diante do impacto dos ativos intangíveis no mercado, cabe perguntar: afinal, quanto vale o que é intangível? A valoração econômica de bens e serviços que não possuem valor no mercado não é simples. Mesmo que atualmente as informações sejam consideradas bens de consumo, é muito difícil avaliar quanto custa a informação, de fato.

Diante disso, muitas áreas do conhecimento se dedicam a estudar a valoração de ativos intangíveis e, entre essas áreas, destaca-se a economia do meio ambiente. Na segunda metade do século XX, quando as pessoas começaram a notar o impacto negativo da ação humana no meio ambiente, cresceu a necessidade de avaliar o valor de bens naturais, a fim de medir adequadamente o impacto que as ações humanas no meio ambiente influenciam no bem-estar da sociedade.

Nessa dissertação, escolheu-se apresentar os principais métodos de valoração de recursos ambientais, com o intuito de servir de parâmetro para avaliação de bens informacionais. Para entender as metodologias de valoração de recursos ambientais, é necessário entender o conceito de valor. 


\subsection{Valor}

Apesar da associação comum entre valor e preço, proveniente das abordagens econômicas, o conceito de valor é objeto de estudo de diversas áreas do conhecimento e todas essas áreas são importantes para a determinação do valor de algo que não possui valor de mercado. Valor não é apenas a representação do custo de produção de determinado produto. O valor de um produto expressa, sobretudo, a importância atribuída pelo consumidor, levando em consideração diversos fatores culturais, sociais, religiosos etc. Goodman e Cohen (2004 apud FERREIRA, 2007, p. 14) afirmam que os bens de consumo não são consumidos apenas por suas características materiais, pois são ainda mais consumidos pelo que representam: seus significados, suas associações e nas percepções de seu consumidor sobre sua subjetividade.

Silva (2012, p. 79) diz que a atribuição de valor a bens e serviços é a razão principal das duas maiores escolas do pensamento econômico: a marxista e a neoclássica. De um lado, Marx defendia que o valor dependia da quantidade de trabalho socialmente incorporado na produção de um bem ou serviço. Do outro lado, a escola neoclássica defende que o valor é determinado pela utilidade. O autor apresenta, assim, as teorias do valortrabalho e do valor-utilidade, na teoria econômica:

A teoria do valor-utilidade contrapõe-se à chamada teoria do valor-trabalho, desenvolvida pelos economistas clássicos (Malthus, Adam Smith, Ricardo e Marx). A teoria do valor-utilidade pressupõe que o valor de um bem se forma por sua demanda, isto é, pela satisfação que o bem representa para o consumidor. Ela é, portanto, subjetiva e considera que o valor nasce da relação do homem com os objetos. Representa a chamada visão utilitarista, em que prepondera a soberania do consumidor, pilar do capitalismo.

A teoria do valor-trabalho considera que o valor de um bem se forma do lado da oferta, por meio dos custos do trabalho incorporados ao bem. Os custos de produção eram representados basicamente pelo fator mão-de-obra, em que a terra era praticamente gratuita (abundante) e pouco significativa. Pela teoria do valor-trabalho, o valor do bem surge da relação social entre homens, dependendo do tempo produtivo (em horas) que eles incorporam na produção de mercadorias. Nesse sentido, a teoria do valor-trabalho é objetiva (depende de custos de produção).

A teoria do valor-utilidade veio complementar a teoria do valor-trabalho, pois não era mais possível predizer o comportamento dos preços dos bens apenas com base nos custos da mão-de-obra (ou mesmo custos em geral) sem considerar o lado da demanda (padrão de gostos, hábitos, renda, e outros). Além disso, a teoria do valor-utilidade permitiu distinguir o valor de uso do valor de troca de um bem. $\mathrm{O}$ valor de uso é a utilidade que ele representa para o consumidor. $\mathrm{O}$ valor de troca se forma pelo preço no mercado, pelo encontro da oferta e da demanda do bem. (SILVA, 2012, p. 79) 
O conceito de utilidade está ligado a variáveis subjetivas e psicológicas que mudam de individuo para individuo. Vasconcelos (2008 apud SILVA, 2012, p. 79) define utilidade como qualidade que os produtos possuem para satisfazer as necessidades humanas.

O desenvolvimento da escola neoclássica permitiu a valorização de recursos naturais e da força de trabalho como fatores de produção escassos e o valor passar a ser assimilado por preços de mercado e obtido a partir da inter-relação entre utilidade e produtividade. (AMAZONAS, 1994 apud OLIVEIRA JUNIOR, 2003, p. 44)

A teoria neoclássica, assim, começa a abordar os aspectos mais amplos da economia, ou seja, os processos produtivos, as relações existentes entre demanda e oferta, preços de mercado, valor de mercado e a utilização de recursos naturais como bens escassos. A partir disso, tornou-se possível o desenvolvimento de um campo denominado economia do meio ambiente, cuja preocupação era explicitar o valor dos bens naturais. (OLIVEIRA JUNIOR, 2003, p.44)

\subsection{Valoração econômica de bens intangíveis e o legado da economia do meio ambiente}

O valor de mercado funciona como critério para avaliar bem tangíveis, mas não é adequado para a valoração de bens intangíveis. Conforme a economia foi acompanhando as mudanças ocorridas na sociedade nas ultimas décadas, foi-se observando a necessidade de estabelecer métodos e critérios para a valoração de bens que não possuem valor de mercado.

A valoração econômica parte do principio de que as pessoas atribuem prioridades e importância a todas as coisas, de acordo com um critério subjetivo. Assim, torna-se possível listar, enumerar e classificar as coisas avaliadas. Esse é o princípio usado por Randall et al. (1999 apud SILVA, 2012, p. 80), ao afirmarem que as preferências de consumo de cada indivíduo são organizadas racionalmente, e por Motta (2006 apud SILVA, 2012, p.80), ao afirmar que os consumidores tentam maximizar o bem-estar, de acordo com os suas preferências e restrições orçamentárias, comparando o preço e os ganhos de satisfação. Portanto, valorar economicamente um recurso consiste em determinar quanto melhor, ou pior, estará o bem-estar das pessoas devido às mudanças da quantidade de bens e serviços, seja na apropriação por uso ou não. (FURIO, 2006, p. 24; Motta,1997, p.13)

A partir da avaliação da importância e prioridade dos bens que cada indivíduo faz para aumentar seu bem-estar, é possível determinar monetariamente a importância desses bens e, por conseguinte, sua disposição a pagar/doar para manutenção e ou ampliação do seu bem estar. 
Motta (1995 apud SILVA, 2012, p. 80) afirma que o conceito de disposição para pagamento é a soma de dinheiro que as pessoas estão dispostas a sacrificar para poderem consumir um bem ou serviço. Assim, é possível também mensurar a soma de dinheiro que as pessoas estão dispostas a aceitar como compensação por não terem acesso ao consumo de um determinado bem ou serviço.

Muitos avanços foram feitos pela área de economia do meio ambiente a respeito da valoração de bens intangíveis. Isso se deve às mudanças no pensamento econômico características da segunda metade do século XX, quando começaram as tentativas de conciliar o crescimento econômico juntamente com conservação do meio ambiente, ao observar que a ação humana provocava desastres ambientais.

Até meados da década de 60, o meio ambiente era visto como sendo uma fonte inesgotável de recursos, que deveriam ser usados para a produção de bens e, assim, satisfazer as necessidades dos seres humanos. Cechin (2010 apud CARNEIRO, 2014, p.11) afirma que nenhuma escola econômica explicitava a entrada de recursos naturais e a saída de resíduos no processo de produção, fazendo com que o sistema econômico fosse visto com sendo fechado e circular, como sistemas mecânicos. Esse reducionismo ainda se encontra presente na economia neoclássica, chamado de diagrama de fluxo circular e apresenta apenas a circulação de produtos, insumos e dinheiro entre as famílias e empresas em mercados de fatores de produção e bens e serviços (CECHIN; VEIGA, 2010 apud CARNEIRO, 2014, p. 11).

Ainda de acordo com Cechin (2010, apud CARNEIRO, 2014, p. 11), a mudança desse pensamento começou com Nicholas George-Roegen (1906-1994), que é considerado o pai da economia ecológica. George-Roegen comparou o sistema econômico com um sistema entrópico, em que são necessárias constantes entradas de energia, devido à perda de energia que é dissipada em forma de calor, que não pode ser utilizada novamente.

Uma grande contribuição da economia neoclássica para o campo ambiental diz respeito ao uso ótimo dos recursos ambientais, onde procura-se uma eficiente exploração dos recursos naturais. (ENRIQUEZ, 2010 apud CARNEIRO, 2014, p. 11). Para isso, baseia suas análises no estudo das externalidades positivas e negativas de uma atividade econômica para o bem-estar da sociedade. As externalidades negativas são vistas como falhas de mercado, cujo primeiro passo para a correção é a atribuição de valores financeiros aos bens naturais. Tendo em vista que os bens naturais não possuem valor de mercado, por serem gratuitos, os economistas neoclássicos passaram a estimar o valor do meio ambiente com base na utilidade dos recursos naturais e nas preferências individuais que determinam a oferta e a demanda por 
determinado bem ou serviço ambiental. (NOGUEIRA; MEDEIROS; ARRUDA, 2000; VIVIEN, 2011 apud CARNERO, 2014, p. 12)

A valoração dos bens e serviços ambientais é um valioso recurso para a diminuição das assimetrias de informação encontradas nas negociações relacionadas ao meio ambiente. As informações geradas pelas metodologias de valoração são grande relevância para toda a sociedade, tendo em vista que os bens ambientais são considerados bens públicos. O cálculo do valor econômico dos bens e serviços ambientais direcionam as discussões e fornecem dados suficientes para fazer escolhas que podem ter grandes impactos no bem-estar da sociedade.

Diante da impossibilidade de atribuir valores de mercado para determinar diretamente o valor de bens e serviços ambientais, um grande legado da Economia do Meio Ambiente foi a criação de métodos de valoração baseados no uso e no não-uso de bens ambientais. Na literatura, são apresentados alguns modelos de valoração aplicados ao meio ambiente. Barcelos (2014, p.74-76) destaca três abordagens:

Valoração econômica de recursos ambientais (VERA): o valor dos recursos ambientais é medido a partir de duas variáveis: valor de uso e valor de não-uso, sendo representado pela seguinte fórmula:

$$
\mathrm{VERA}=(\mathrm{VUD}+\mathrm{VUI}+\mathrm{VO})+\mathrm{VE}
$$

Nessa fórmula, o valor de uso é separado em valor de uso direto (VUD), valor de uso indireto (VUI) e valor de opção (VO). Além disso, o valor de não-uso é representado pela expressão 'valor de existência' (VE). (MOTTA, 2006; MAIA et al., 2004 apud BARCELOS, 2014, p. 74)

Valor econômico do ambiente (VEA): esse método também divide o valor dos recursos em valor de uso e não uso, sendo representado pela seguinte formula:

$$
\mathrm{VEA}=(\mathrm{VU}+\mathrm{VO})+\mathrm{VE}
$$

Nessa fórmula, o valor de uso é dividido em valor de uso (VU) e valor de opção (VO). O valor de não uso é representado pelo valor de existência (VE). (MARQUES E COMUNE, 1999; CUNHA, 2008 apud BARCELOS, 2014, p.76) 
Valor econômico total (VET): apresentado por Nogueira e Medeiros (1998 apud BARCELOS, 2014, p. 75), o VET apresenta a seguinte formula:

$$
\mathrm{VET}=(\mathrm{VU}+\mathrm{VO}+\mathrm{VQO})+\mathrm{VE}
$$

Nessa fórmula, o valor de uso é representado pelo valor de uso (VU), valor de opção (VO) e valor de quase-opção (VQO). O Valor de não-uso, mais uma vez é representado pelo valor de existência (VE).

\subsection{Valor econômico total (VET)}

Entre os métodos apresentados de valoração criados no âmbito da economia do meio ambiente, destaca-se o Valor Econômico Total (VET). A composição do valor econômico total não é consenso na literatura, pois alguns consideram que existe um valor de quase-opção e outros consideram que existe um valor de herança. Porém existe uma afirmação que é consenso em toda a literatura: o valor econômico total é formado pela soma do valor de uso com o valor de não-uso (OLIVEIRA JUNIOR, 2003, p. 53). A seguir se encontram as possíveis composições desses dois tipos de valor

$$
\text { VET }=\text { VALOR DE USO + VALOR DE NÃO-USO }
$$

Assim como nas metodologias apresentadas no capítulo anterior, o resultado da valoração econômica de determinado bem é a soma do valor de uso e de não-uso. Por ser o princípio básico da criação das metodologias de valoração ambiental, esse será o princípio adotado nessa dissertação, para fins comparativos de aplicação na área de informação. No VET, o valor de uso costuma ser o resultado de duas variáveis:

Valor de uso: essa variável engloba o uso direto, o uso indireto, o valor de opção e o valor de quase-opção de determinado bem. Mattos (2004 apud SILVA, 2012, p. 81) diferencia o valor de uso de um bem, de seu valor intrínseco. Enquanto o valor de uso é atribuído pelas pessoas que de fato utilizam determinado bem, o valor intrínseco diz respeito a todos os valores potenciais desse bem. Assim, o valor de uso compreende a soma dos valores de uso direto e indireto. 
$\mathrm{O} \underline{\text { uso direto }}$ diz respeito ao valor que as pessoas atribuem ao bem pelo fato de utilizar dele diretamente, a partir da extração, visitação ou outras atividades de produção e consumo direto (FURIO, 2006, p. 23). Podem-se citar dois exemplos de uso direto: o primeiro diz respeito às comunidades ribeirinhas da Região Norte do Brasil que utilizam os rios em suas atividades diárias, inclusive consumo e limpeza; outro exemplo é o de moradores que utilizam o acervo histórico de uma biblioteca considerada patrimônio cultural. Obara (1999, apud PERRENOUD, 2010, p. 34) diz que, na área de meio ambiente, estão incluídos os produtos extraídos de forma sustentável e que podem ser comercializados legalmente, incluindo os produtos ilegais que foram retidos, além dos benefícios relacionados ao lazer, recreação, prática de turismo, estética da paisagem, valor espiritual, educação e pesquisa, sendo determinado qualitativa e quantitativamente.

O uso indireto diz respeito ao valor atribuído pelo consumo e benefício indireto de determinado bem. Na economia do meio ambiente, isso se exemplifica no uso de funções ecossistêmicas, como a proteção do solo e a estabilidade climática proveniente da preservação das florestas. Obara (1999 apud PERRENOUD, 2010, p. 35) afirma que o valor de uso indireto inclui os benefícios derivados dos serviços que as áreas naturais fornecem como aporte aos bens e serviços de produção, ou seja, os valores estimados no controle da erosão, manutenção da qualidade da água, controle climático, preservação da biodiversidade e do material genético etc.

O valor de opção é atribuído pelo individuo que conhece o valor de determinado bem, mas não o usa e está disposto a pagar pela opção de usá-lo no futuro. Barcelos (2014, p. 74) afirma que valor de opção é atribuído à preservação de recursos que podem ser ameaçados, para uso direto e indireto no futuro próximo; e de Ortiz (2003 apus PERRENOUD, 2010, p. 35) que diz que esse é o valor que o indivíduo estaria disposto a pagar para manter o recurso ambiental para uso futuro. Mota (2001 apud PERRENOUD, 2010, p. 35) enfatiza que, caso o futuro seja certo quanto às preferências do consumidor e às disponibilidades futuras, o valor de opção será zero. Porém, a incerteza do futuro gera expectativas no consumidor, que se declara disposto a pagar um valor no presente, para ter opção de usar o bem no futuro.

Barcelos (2014, p. 75) apresenta o valor de quase-opção, cuja diferença se dá quanto à incerteza de que o bem preservado será útil no futuro. Nessa modalidade, é avaliado o valor de reter as opções de uso futuro, dada a hipótese de que o conhecimento científico e técnico pode crescer e trazer benefícios econômicos e sociais. O valor de quase-opção é importante para demonstrar que as estimativas de valoração podem variar ao longo do tempo, 
sobretudo quando as metodologias de valoração incorporam alternativas tecnológicas de prevenção e reparação dos danos causados, bem como se aprimoram técnicas de quantificar os impactos dos danos ao bem valorado (NOGUEIRA et al., 2000; MAIA, 2002; HACKETT, 2009 apud MUÑOZ, 2015, p. 21).

Valor de não-uso ou valor de existência: O valor de existência está dissociado de uso e deriva de uma posição moral, cultural, ética ou altruística em relação à existência de determinado bem ou recurso, sem indicação de uso atual ou futuro pra ninguém (FURIO, 2006, p. 23; BARCELOS, 2014, p.75). Como exemplo, pode-se citar a preservação das espécies em extinção em seu habitat, como ursos e baleias, que habitam regiões totalmente despovoadas e não trariam nenhum benefício direto ou indireto a alguém.

Existe um valor derivado do valor de não-uso, denominado valor de herança e que, segundo Barcelos (2014, p. 75), seria medido pela disposição do individuo em pagar pela preservação de determinado bem, para que as futuras gerações possam ter acesso a ele.

A partir da apresentação das variáveis a serem medidas no VET, Furio (2006, p. 24), salienta a dificuldade para encontrar preços de mercado que reflitam os valores atribuídos pelos indivíduos, principalmente quando se passa do valor de uso para o valor de não-uso. Marques e Comunes (1995 apud BARCELOS, 2014, p. 75) acrescentam que muitos componentes, no caso do meio ambiente, não são comercializados no mercado e o preço dos bens econômicos não refletem o verdadeiro valor dos recursos usados na sua produção. Nogueira (1998 apud BARCELOS, 2014, p.75) complementa que os métodos de valoração tentam obter estimativas plausíveis a partir de situações onde não existem mercados aparentes ou onde os mercados são muito imperfeitos.

Os métodos de valoração apoiam a tentativa de captar as distintas parcelas do valor econômico do recurso. Porém, conforme salientado por Furio (2006, p. 24), cada método apresenta limitações, que quase sempre está associado à sofisticação metodológica, à base de dados exigidos, às hipóteses sobre o comportamento do indivíduo consumidor e aos efeitos do consumo do bem em diversos setores da economia.

\subsection{Métodos de valoração econômica}

A classificação dos métodos de valoração econômica apresenta diferentes abordagens. De acordo com Motta (1978, p. 13), os métodos de valoração mais utilizados são 
os métodos de função de produção e os métodos de função de demanda. Os mesmos métodos, por outro lado são classificados por Maia et al. (2004 apud BARCELOS, 2014, p. 77) entre diretos (que se referem àqueles que captam as preferências das pessoas por meio de mercados hipotéticos ou de bens complementares) e indiretos (referentes àqueles que utilizam uma função de produção). Outra classificação encontrada na literatura é apresentada por Oliveira Junior (2003, p. 58), que divide os métodos entre os baseados nos preços de mercado e os que não são baseados no preço de mercado. Para essa dissertação, será utilizada a classificação de Motta (1978, p.13).

\subsubsection{Métodos de função de produção}

Segundo Motta (2006 apud BARCELOS, 2014, p. 78), são os métodos mais utilizados, devido à sua simplicidade, por meio da função de produção. Nesse tipo de método, é observado o valor do recurso $\mathrm{R}$ em razão de sua contribuição como insumo ou fator de produção de determinado produto P. São conhecidas duas variantes desse método: o método da produtividade marginal e o método dos bens substitutos. Na aplicação na área de meio ambiente, Motta (2006 apud BARCELOS, 2014, p. 78) utiliza uma função de produção

$$
\mathrm{P}=\mathrm{f}(\mathrm{Y}, \mathrm{R})
$$

onde $\mathrm{Y}$ corresponde aos insumos privados e $\mathrm{R}$ aos recursos ambientais com preço igual a zero. Calcula-se, assim, a variação do produto de $\mathrm{P}$ em razão da variação da quantidade do recurso ambiental R utilizada para produzir P. Assim, torna-se possível avaliar o quanto do lucro ou receita líquida de atividade, estimada pela variação do produto $\mathrm{P}$, é resultante da variação de $\mathrm{R}$.

\subsubsection{Método da produtividade marginal}

O método da produtividade marginal parte do principio de que um bem ou serviço, gerado por um recurso ambiental, é conhecido e de que o valor econômico representa apenas valores de uso direto e indireto relativo a bens e serviços ambientais utilizados na produção. (MOTTA, 1997, p. 16)

Sendo assim, o método de produtividade marginal possui a seguinte função de produção: $P=f(Y, R)$, onde o valor econômico de $R$ é um valor de uso dos bens e serviços ambientais. Para calculá-lo, é necessário conhecer a correlação de R em f e, ainda, a variação do nível de estoque e de qualidade de $\mathrm{R}$ em razão da produção do próprio $\mathrm{P}$ ou de outra 
função de produção. Assim, é possível conhecer as funções de dano ambiental ou as funções dose-resposta (DR), onde

$$
\mathrm{R}=\mathrm{DR}(\mathrm{X} 1, \mathrm{X} 2, \ldots, \mathrm{Q})
$$

Sendo que Xi representa às variáveis que, junto com o nível de estoque ou qualidade $\mathrm{Q}$ do recurso natural, afetam a disponibilidade de R. Assim:

$$
\mathrm{DR}=\mathrm{DDR} / \mathrm{DQ}
$$

Debeux (1998 apud FURIO, 2006, p. 27) relaciona as DRs à variação do nível de estoque ou à qualidade de $\mathrm{R}$, onde danos físicos ao meio ambiente são provocados com a produção $\mathrm{P}$ ou $\mathrm{T}$, com o sentido de identificar o decréscimo de $\mathrm{R}$ para a produção de $\mathrm{P}$.

Motta (1997, p.17) apresenta dois exemplos da aplicação desse método na área de meio ambiente: o primeiro é um estudo econômico sobre produtividade agrícola, a "dose" seria a erosão do solo e a "resposta" o correspondente comprometimento da safra. O outro exemplo apresentado pelo autor permite a visualização do problema em cadeia e pode ser observado na indústria de produção de álcool. Quando a produção de álcool T aumenta o nível de poluição da água $\mathrm{Q}$, que por sua vez afeta a qualidade da água $\mathrm{R}$, comprometendo a produção do setor pesqueiro P. Se a água é utilizada para produzir P, determinada a DR da água pela produção de $\mathrm{T}$, sendo conhecida a função de produção de $\mathrm{P}$, determina-se perda em P.

Furio (2006, p. 28) ainda ressalta que a complexidade da dinâmica dos ecossistemas ainda não é suficientemente conhecida para que se possam estabelecer relações precisas de causa e efeito, o que dificulta a estimação da função de dano.

\subsubsection{Método de Mercado dos bens substitutos}

Outros métodos que utilizam preços de mercado podem ser adotados com base nos mercados de bens substitutos, caso existam variações marginais de quantidade de um produto industrializado. Esses métodos são importantes para os casos onde a variação do produto industrializado não oferece preços observáveis de mercado ou são de difícil mensuração. Esse é o caso dos produtos que são também um bem ou serviço ambiental consumido gratuitamente. É o caso também dos substitutos perfeitos, como o caso do gás liquefeito de petróleo, que pode substituir o gás natural quando há escassez, mantendo o nível de bem estar e expectativa dos usuários. (MOTTA, 1998 apud FURIO, 2006, p. 28).

Debeux (1998 apud BARCELOS, 2014, p. 80) informa que diante da eventual impossibilidade de calcular as perdas das variações de produto e dos recursos ambientais, por 
conta da inexistência de preços de mercado, as perdas são calculadas a partir de seus substitutos perfeitos.

Maia (2002 apud BARCELOS, 2014, p.80) afirma que diante da escassez ou perda de qualidade de um bem ou serviço, a procura por substitutos irá aumentar, a fim de manter o bem-estar da população. O autor afirma também que é muito difícil encontrar na natureza um substituo perfeito, sobretudo pela complexidade dos bens e grande variedade de funções, como é o caso da água.

Se uma função da produção $\mathrm{P}=\mathrm{f}(\mathrm{Y}, \mathrm{R}), \mathrm{R}$ tem em $\mathrm{S}$ seu substituto perfeito, a função de produção pode ser demonstrada em

$$
P=f(Y, R+S)
$$

onde a perda de uma unidade de $\mathrm{R}$ pode ser compensada por uma quantidade constante de $\mathrm{S}$. Sendo $\mathrm{P}$ constante, uma unidade a menos de R será compensada por uma quantidade a mais de $\mathrm{S}$ e a variação de R passa a ser valorada pelo preço de mercado de S. O P, sendo um bem ou serviço ambiental sem preço de mercado, poderia ser substituído por $\mathrm{S}$, se não houvesse função de produção ou dose-resposta disponível.

Motta (1997, p. 18) apresenta três aplicações do método com base nos preços substitutos:

Custo de reposição: Quando o custo de S representa gastos do consumidor para garantir o nível desejado de P ou R. Esse método se baseia nos gastos necessários para reparação de um bem danificado, para fazer uma estimativa dos benefícios gerados por esse recurso ambiental. O calculo é baseado nos preços de mercado para repor ou reparar o bem ou serviço danificado, observando que o recurso ambiental deve ser substituído. Uma desvantagem desse método é que, por maiores que sejam os gastos envolvidos na reposição, nem todas as complexas propriedades de um atributo ambiental serão repostas pela simples substituição dos recursos. Um exemplo disso é a o reflorestamento de uma área desmatada, que ajuda a ter uma aproximação dos prejuízos econômicos, mas não recupera toda a biodiversidade perdida. (MAIA, 2002, apud BARCELOS, 2014, p. 81)

Custos evitados: Quando os custos de S representam os gastos do consumidor para não alterar o produto $\mathrm{P}$ que depende de $\mathrm{R}$. Nesse método, o gasto do valor de um recurso ambiental é medido por meio dos gastos com atividades defensivas substitutas ou complementares, para aproximar o valor monetário sobre as mudanças do atributo ambiental. Um exemplo da aplicação desse método é a escolha do indivíduo em comprar água mineral, presumindo estar 
livre dos possíveis males de poluição e, assim, valorando sua disposição a pagar pela água descontaminada. (MAIA, 2002 apud BARCELOS, 2014, p. 81)

Custos de controle: Quando o dano ambiental pode ser valorado pelos custos de controle que empresas ou consumidores realizam para que se evite a perda de qualidade ou quantidade de R. Um exemplo da aplicação desse método é o tratamento de esgoto para evitar a poluição dos rios. (MAIA, 2002 apud BARCELOS, 2014, p. 82)

\subsubsection{Métodos de função de demanda}

Diferentemente dos métodos de função de produção, que analisam casos associados à produção de um recurso privado e geralmente assumem que as variações na oferta do recurso ambiental não alteram os preços de mercado, os métodos de função de demanda admitem que a variação de disponibilidade de um recurso de bens e serviços ambientais altera o nível de bem-estar das pessoas e, portanto, é possível perceber e identificar a disposição a pagar ou aceitar essas variações (MOTTA, 1997, p. 22).

Existem duas variantes desse método: métodos dos bens complementares e o método da valoração contingente.

\subsubsection{Método de mercado de bens complementares}

Motta (1997, p.22) afirma que do mesmo jeito que mercados de bens e serviços privados substitutos a bens e serviços ambientais podem oferecer medidas de valor de uso dos recursos ambientais quando estes representam a produção de um bem de demanda final que não tem preço observável, é possível que os mercados de bens e serviços privados complementares a bens e serviços ambientais podem ser utilizados para mensuração do valor de uso de um recurso ambiental.

Motta (1997, p.22) também afirma que bens perfeitamente complementares são consumidos em proporções constantes entre si. Assim, é possível gerar informações sobre a demanda de bens ou serviços ambientais em risco a partir da análise dos bens e serviços complementares. Se um bem é um complementar perfeito a outro bem, seu valor será zero se a demanda pelo outro bem for zero.

Debeux (1998 apud FURIO, 2006, p. 30) apresenta a função de utilidade da seguinte forma: dada uma função de utilidade 


$$
\mathrm{U}=\mathrm{f}(\mathrm{Q}, \mathrm{X})
$$

onde $\mathrm{Q}$ corresponde ao recurso natural sem valor de mercado complementar a $\mathrm{X}$, que representa um vetor de quantidades de bens que estão no mercado. Q influi na demanda de $\mathrm{X}$, e Q pode ser calculado a partir da estimativa da demanda de X para vários níveis de Q.

Os métodos de mercado de bens complementares podem ser medidos por meio da aplicação de duas variantes: método dos preços hedônicos e método do custo de viagem.

Método dos preços hedônicos: o fundamento desse método está na identificação de atributos e características de um bem composto privado cujos atributos sejam complementares a bens ou serviços ambientais. A partir da identificação dessa complementaridade, é possível mensurar o preço implícito do atributo ambiental no preço de mercado quando outros atributos são isolados. Um exemplo de aplicação desse método são os preços de propriedade, que variam de acordo com características naturais intrínsecas a cada propriedade, como a qualidade do ar, do solo ou a proximidade de um sitio natural. A partir dessas diferenças, é possível identificar a disposição a pagar dos indivíduos para usufruir desses bens. (MOTTA,1997, p. 23)

Lesser (1997 apud BARCELOS, 2014, p. 31) enfatiza que embora não seja possível precificar os bens ambientais, é possível decompor os preços de mercado em algumas características, inclusive em bem ambientais. Assim, o preço de uma casa onde há ruído por ser próximo de um aeroporto ou onde há incômodo de odor por ser localizada perto de uma refinaria, servem de apoio à valoração dos impactos do cheiro e do barulho causado nessas casas.

Por meio da função hedônica de preço, pode-se estimar o valor dos atributos de um ou vários bens e serviços ambientais implícitos no valor de um bem privado, por meio da seguinte função:

$$
\mathrm{Pi}=\mathrm{f}(\text { ai1, ai2, ai3,..., Ei) }
$$

onde P é o preço de determinada propriedade privada, A sãos os atributos da propriedade e E é o nível do bem ou serviço ambiental da propriedade i. O preço de R é então dado por $\mathrm{dF} / \mathrm{dE}$ e PE a disposição a pagar por uma variação de E.

Método do custo de viagem: Para Motta (1997, p. 27), esse é o método mais indicado para a estimação de demanda por bem ou serviço ambiental, com base na demanda de atividades recreacionais, associadas complementarmente ao uso do bem ou serviço ambiental que pode ser, por exemplo, um sítio natural. A curva de demanda destas atividades pode ser construída com base nos custos de viagem ao sítio natural, onde o bem ou serviço é oferecido. 
Basicamente, o custo de viagem representa o custo de visitação do sítio natural. O autor também aponta que a distância afeta o custo total de visitação e o número de visitas feito por determinado individuo, portanto é importante observar a distância da localidade onde os visitantes moram e outros dados relacionados à situação socioeconômica dos visitantes. Uma forma de fazer o recolhimento de dados seria o preenchimento de questionário feito pelos próprios visitantes, durante uma visita ao sitio. Essa metodologia funciona em outras ocasiões, como por exemplo, uma biblioteca ou museu considerado patrimônio cultural.

Lesser (1997 apud BARCELOS, 2014, p.32) destaca três observações importantes sobre o método. A primeira: o custo de uso recreacional é maior do que o preço admitido. Inclui-se aí, o custo monetário e o custo do tempo de viagem para o local da área recreacional. Segunda observação: pessoas que residem em diferentes distâncias da área recreacional se deparam com diferentes custos de utilização. A terceira observação diz respeito ao valor que as pessoas atribuem a área de recreação não estar diretamente relacionado à distância. Custos de viagem podem ser usados como atributos para preços derivados da curva de demanda para áreas recreacionais.

Debeux (1998 apud BARCELOS, 2014, p. 32) explica que se estima a demanda por um sítio natural, por meio de um procedimento econométrico, com base nos custos realizados pelos usuários do sítio, para acessar o local. O custo de visitação a um sítio natural específico pode ser considerado a máxima disposição a pagar do usuário pelos serviços ambientais de $\mathrm{R}$.

A função, portanto, é expressa da seguinte maneira:

$$
\mathrm{Vi}=\mathrm{f}(\mathrm{CV}, \mathrm{X} 1, \ldots, \mathrm{Xn})
$$

Estima-se a taxa de visitação de cada zona i (Vi) da amostra (por exemplo, visitas por cada mil habitantes) que pode ser correlacionada estatisticamente com os dados amostrais do custo médio de viagem da zona (CV) e outras variáveis sócio-econômicas zonais (Xi).

\subsubsection{Método da Valoração contingente}

Motta (1997, p. 31) afirma que, ao contrário dos métodos de valoração que se baseiam na existência e no uso de bens, o método da valoração contingente é o único que permite a avaliação do valor de existência dos bens.

Valoração contingente é o método que consiste na aplicação de questionários amostrais para quantificar monetariamente as preferências individuais por bens ambientais que não são comercializados. Este método tem como objetivo revelar a disposição a pagar 
(DAP) dos indivíduos pela manutenção e/ou restauração de um bem ou serviço ambiental, ou até o valor que o indivíduo estaria disposto a aceitar/receber (DAA) como uma forma de compensação para tolerar uma diminuição na qualidade ambiental ou simplesmente para manter uma área intacta. (PERRENOUD,2010 apud BARCELOS, 2014, p. 84)

Motta (2006 apud BARCELOS, 2014, p. 85) diz que esse método estima os valores da DAP e da DAA com base em mercados hipotéticos que são simulados por intermédio de pesquisas em campo que questionam as disposições dos entrevistados em pagar ou aceitar as alterações na disponibilidade qualitativa ou quantitativa do meio ambiente.

A função desse método é expressa pela função:

$$
\text { DAPi (ou DAAi) }=f(Q i j, Y i, S i, E j)
$$

onde Qij representa o número de visitas, Yi representa a renda, Si representa os fatores sociais (ou outras variáveis explicativas) e Ej representa o parâmetro da qualidade ambiental do bem a ser valorado.

\subsection{O uso dos métodos de valoração em outros contextos}

A metodologia criada no âmbito da economia do meio ambiente tem se provado bastante eficiente como artifício para a valoração de bens intangíveis relacionados à natureza e, por esse motivo, seus princípios têm sido utilizados na valoração de outros tipos de bens intangíveis.

Silva (2012, p. 83) esclarece que todos os valores empregados na valoração ambiental se adaptam perfeitamente à análise do patrimônio cultural. Mathieu (2000 apud SILVA, 2003, p. 83) exemplifica que é irrelevante a diferença entre um benefício recreativo decorrente de uma pescaria ou a beleza cênica ao se contemplar uma árvore ou um prédio antigo. O processo de valoração de bens com valor histórico e artístico adota o conceito de valor econômico total.

A valoração de patrimônio artístico e cultural procurar responder questões da mesma natureza que a economia do meio ambiente. A partir da valoração desses bens, é possível avaliar, por exemplo, a perda irreversível de uma pintura histórica, a restauração de uma casa antiga de um centro histórico, o calculo de indenização por depredação de bens histórico-culturais etc.

Obviamente, os critérios que precisam ser observados nos bens valorados são diferentes. Por exemplo, a autoria e a técnica são importantes para avaliar o valor de uma obra de arte; ou o ponto geográfico e a conservação são importantes para avaliar um edifício 
histórico; e a raridade é importante para avaliar o valor de um exemplar físico de um livro. Porém, os critérios de valorar a disposição dos cidadãos em pagar para usar ou conservar determinado bem permanecem iguais.

No Brasil, existe uma norma técnica quês estabelece princípios para fazer a valoração de determinados tipos de bens intangíveis. A NBR 14653/2001, chamada de 'Avaliação de bens' possui sete partes e cada parte trata da valoração de um tipo de bem, a saber: Parte 1: Procedimentos gerais; Parte 2: Imóveis urbanos; Parte 3: Imóveis rurais; Parte 4: Empreendimentos; Parte 5: Máquinas, equipamentos, instalações e bens industriais em geral; Parte 6: Recursos naturais e ambientais; e Parte 7: Patrimônios históricos.

A norma indica a consideração das características intrínsecas de cada tipo de bem, mas o procedimento de valoração indicado é o VET. Sobre as prescrições da norma, tem-se que:

A norma, orientada pelo disposto em sua $6^{\mathrm{a}}$ parte, afirma que os métodos comparativo direto de dados do mercado, involutivo, evolutivo, de custo e de capitalização da renda podem ser utilizados na avaliação de bens dos patrimônios histórico e artístico. A seleção do método e da abordagem a serem empregados dependem da disponibilidade de dados necessários à aplicação de cada um deles. A norma orienta que, quando houver um mercado consumidor para os bens a serem avaliados, se dê preferência pelo método comparativo direto de dados do mercado, seguindo-se as prescrições da NBR 14653-2, NBR 14653-3, NBR 14653-5, conforme a natureza do bem a ser avaliado. Para os demais casos, a NBR 14653-7 indica a utilização de metodologias amparadas na disposição a pagar (DAP): método de preços hedônicos, método do custo de viagem, método da avaliação contingente, método do custo de oportunidade. (STEIGLEDER,2010 apud SILVA, 2012, p. 83)

Com isso, percebe-se que os procedimentos de valoração precisam levar em consideração as características de cada tipo de bem e deve-se dispor da maior quantidade de informação possível, a fim de apresentar um resultado mais próximo da realidade.

No próximo capítulo serão apresentados os procedimentos metodológicos adotados na literatura para a valoração de bibliotecas. Sabe-se que a informação possui características muito peculiares relacionados à sua forma, como o baixíssimo custo de reprodução. Como o VET é avaliado na valoração de um bem cuja lei de escassez funciona de forma diferente da tradicional é apresentado no próximo capítulo. 


\section{BIBLIOTECAS: ORGANIZAÇÕES EM MUDANÇA}

Durante muitos séculos, as bibliotecas foram consideradas o principal local onde as pessoas poderiam ter acesso fácil a informações, sejam elas atuais, históricas, culturais, especializadas, recreativas etc. Quando as informações ainda eram consideradas apenas a partir do suporte onde elas se encontravam, o acesso à informação era restrito e, muitas vezes, de alto custo. A forma mais barata de ter acesso aos jornais diários, às revistas especializadas, aos livros e às bases de dados era ser sócio de um serviço de biblioteca. Porém, conforme foi explicado no capítulo 1, o avanço das tecnologias de informação mudaram os conceitos de tempo e espaço, no que diz respeito ao acesso à informação. Quando os recursos informacionais deixaram de ser vinculados ao suporte físico e começaram a migrar para o suporte digital a preços muito baixos, as pessoas deixaram de ter a necessidade de ir fisicamente a algum lugar para ter acesso a informações.

A mudança de paradigma na produção e acesso à informação traz muitos benefícios. O processo de comunicação da informação científica, por exemplo, se tornou muito mais rápido, seguindo uma tendência de alguns séculos, principalmente por conta da evolução da tecnologia. Normalmente, o processo de edição de um livro pode demorar muito tempo, o que pode ser muito prejudicial para a comunicação dos resultados de pesquisa. Por conta disso, o mercado de periódicos científicos cresceu consideravelmente, pois, enquanto a edição de um livro poderia levar anos, a edição de periódicos científicos levava apenas alguns meses. Porém, com os avanços das tecnologias de informação, a quantidade de pesquisas produzidas simultaneamente todos os dias aumentou e a espera de alguns meses para a publicação e acompanhamento dos resultados de pesquisas não condiz mais com a sociedade atual, baseada no imediatismo. Com o advento da internet e a popularização do acesso à informação, os pesquisadores podem publicar os resultados de suas pesquisas instantaneamente, com o alcance nunca imaginado com o uso das edições impressas de revista. Assim como aconteceu com a comunicação científica, outros mercados de informação estão migrando para a internet. (BOMFÁ et al., 2009, p. 198)

Embora as facilidades de acesso e divulgação de informações gerem a impressão de que todas as informações estão disponíveis na internet, isso é apenas uma falácia (McCallum; Quinn, 2013, p. 55). Existe, de fato, uma grande quantidade de informação sendo produzida digitalmente todos os dias e a todos os momentos, em uma quantidade que não é humanamente possível de gerir. Diante de todo o universo de informação disponível, é necessário saber identificar como e onde encontrar a informação útil, em tempo hábil. Uma 
barreira que impede o acesso à informação útil na internet é a própria disponibilidade, pois ainda existe uma grande quantidade de informações sendo produzidas e reproduzidas em suportes físicos e que não possuem previsão de serem digitalizadas. Outra barreira diz respeito à acessibilidade, pois apenas a disponibilidade não garante o acesso, como é o caso das publicações pagas, das publicações em outros idiomas, das publicações que não são encontradas devido à fala de organização etc. A última barreira importante a ser mencionada é a confiabilidade das informações. Essas três barreiras exigem do usuário um conjunto de conhecimentos, habilidades e atitudes descritos por Campello (2003, p. 32) como competência informacional.

Pode-se observar, a partir desse cenário, que as bibliotecas deixaram de ser as principais provedoras de acesso à informação e o bibliotecário deixou de ser o único mediador entre o usuário e a informação, tendo em vista que os usuários se tornam a cada dia mais independentes em suas buscas por informação. Assim, houve uma grande mudança nos princípios da profissão e os bibliotecários precisaram adequar suas atividades profissionais a uma nova demanda informacional. Atualmente, as bibliotecas funcionam de maneira híbrida, entre o físico e o digital, e trabalham cada vez mais conectadas a redes, a fim de atender a toda demanda proveniente de seus usuários e otimizar seus próprios trabalhos. (SILVA, 2005, p. 20)

A internet, ao contrário do pensamento comum, não é concorrente das bibliotecas. A internet é capaz de potencializar o uso e a importância das bibliotecas na sociedade atual. Inclusive, as bibliotecas começaram a oferecer o acesso à internet como um de seus serviços, que pode ser muito útil em bibliotecas públicas, por exemplo, nas atividades de cunho social, tendo em vista que nem todos os usuários possuem acesso à internet em casa. Em bibliotecas institucionais, por exemplo, a internet é necessária para complementar as buscas por informação e para promover acesso a bases de dados.

Até esse momento, já foram citados dois tipos de bibliotecas: públicas e institucionais. O perfil das bibliotecas variam de acordo com o perfil de seus usuários. Assim, os bens informacionais disponibilizados em cada biblioteca obedecem a políticas internas, para que atendam as necessidades específicas de seu público-alvo ou mantenedor. Para exemplificar, a seguir serão apresentados seis tipos de biblioteca.

Existem bibliotecas que são localizadas em escolas e instituições de ensino e são conhecidas como bibliotecas escolares. Essas bibliotecas possuem a função de atender ao público escolar, oferecendo suporte aos professores e demais profissionais da educação, na formulação de seus planos de aula e nas atividades relativas ao desenvolvimento intelectual 
dos alunos. Da mesma forma, essa biblioteca também tem a missão de fornecer aos alunos os recursos necessários para o desenvolvimento de suas atividades estudantis. Existe outro tipo de biblioteca semelhante a essa, que está relacionada às instituições de ensino superior: as bibliotecas universitárias, que possuem a missão de servir de suporte às necessidades informacionais de alunos, professores e de toda a comunidade acadêmica, nas atividades de ensino, pesquisa e extensão. (FONSECA, 2007, p. 53)

Algumas bibliotecas normalmente são mantidas pelo Estado e atendem ao público em geral. Essas são as bibliotecas públicas, que possuem acervos com amplitude muito grande, a fim de atender a qualquer usuário com um perfil genérico. Normalmente, essas bibliotecas possuem uma rotina intensa de interação com usuários, por meio de atividades culturais. Com características semelhantes, existem as bibliotecas comunitárias, que atendem às demandas gerais da comunidade onde estão alocadas, mas não são mantidas com orçamento público, mas pela própria comunidade. (FONSECA, 2007, p. 55)

As bibliotecas especializadas possuem acervos e promovem acesso à literatura de sua área de especialização. Normalmente, essas bibliotecas estão ligadas a empresas e centros de pesquisa, o que explica o grau de especialidade de seus bens informacionais, e por isso são conhecidas também como bibliotecas institucionais. Vale observar que nem todas as bibliotecas especializadas estão ligadas a alguma instituição e nem toda biblioteca institucional possui acervo especializado, mas essa associação é baseada na grande maioria de casos. (Cunha; Cavalcanti, 2008, p. 51)

Outra biblioteca é dedicada a preservar a memória bibliográfica de um país e trabalhar com atividades de controle bibliográfico e depósito legal. As bibliotecas nacionais são responsáveis por serem guardiãs de toda a produção bibliográficas de seus países de origem e seus principais usuários são historiadores. (FONSECA, 2007, p. 54)

Os produtos e serviços de cada tipo de biblioteca variam de acordo com as necessidades de seus usuários. Porém, de uma maneira geral as bibliotecas trabalham para promover acesso, disseminação, produção e utilização da informação para um determinado público. Para isso, as bibliotecas dispõem de acervos físicos e digitais organizados sistematicamente para facilitar a recuperação. Dispõem também de serviços de referência, pesquisa e atendimento ao usuário, que visam a disponibilizar ao usuário a expertise de seus funcionários na busca por informações, ajudando ao usuário a encontrar as fontes de informação adequadas, sem desperdício de tempo. Além disso, existem serviços de preservação de memória institucional e obras raras, para bibliotecas institucionais, por 
exemplo; organização de informações, legislações e documentos necessários aos usuários; acesso à internet e a bases de dados bibliográficas específicas etc.

Pode-se observar a partir do conhecimento dos tipos de bibliotecas e dos produtos e serviços informacionais oferecidos por cada uma delas, que se trata de instituições de grande importância e que possuem valores econômicos e sociais que justificam a sua existência. Observa-se também que a internet não supre tudo o que uma biblioteca produz e que, portanto, a perda ou fechamento de uma biblioteca implicaria gastos para conseguir acesso aos serviços prestados por ela. Além disso, observa-se que, independentemente do meio onde a informação está disponibilizada, as bibliotecas não perderam sua principal função que é promover o acesso do usuário à informação desejada. Apesar disso, é muito difícil mensurar o valor econômico de cada biblioteca, assim como é difícil avaliar o retorno que o investimento nelas traz aos seus mantenedores e à sociedade. Por esse motivo, muitas bibliotecas não recebem investimentos e fecham.

A falta de investimentos em bibliotecas, qualquer que seja a especialidade delas, pode estar relacionada com a falta de conhecimento sobre o retorno que os investimentos nessa área podem oferecer. Em situações crônicas, como a que acontece atualmente no Brasil, a falta de investimento e do devido reconhecimento resulta no fechamento de bibliotecas. Isso indica que, além de não saberem sobre o retorno de investimentos, os tomadores de decisão não sabem sobre o valor econômico dos bens e serviços informacionais que já existem nessas bibliotecas.

\subsection{A relevância dos serviços de informação}

Aliado à popularização do acesso à informação e ao crescimento da internet, as recessões econômicas em nível mundial são citada como grandes propulsoras do fechamento de bibliotecas. Autores como Tenopir (2010, p. 40), Keyes (1995, p. 172) e Germano (2011, p. 100) enfatizam que, por conta da crise econômica, as bibliotecas são pressionadas a provarem seus valores aos seus usuários e aos seus mantenedores com mais frequência, a fim de justificarem seus investimentos. Germano (2011, p. 101) ainda enfatiza o fato de que, embora as bibliotecas sejam ameaçadas pelas crises, as crises provam a necessidade de existência de serviços de informação, pois as bibliotecas possuem funções essenciais que impactam na alfabetização de pessoas e no acesso delas à informação, pois uma população bem informada está muito mais preparada para sobreviver e evitar crises catastróficas. 
As bibliotecas sempre precisaram dispor de ferramentas para justificar sua existência a seus mantenedores. Os bibliotecários trabalham com a elaboração de estatísticas de uso, de empréstimos, de pesquisas, de atendimentos etc. Porém, mesmo assim, isso não tem impedido que muitas bibliotecas fechem as portas e tenham seus produtos e serviços descartados, tanto no serviço público, quanto na iniciativa privada. Isso se deve ao pensamento de que, diante da necessidade de busca de informação, caso não exista uma biblioteca, será possível conseguir acesso à informação desejada por outros meios de maneira fácil e gratuita. Além disso, por conta das mudanças proporcionadas pelas tecnologias da informação, os usuários conseguem acesso aos serviços e produtos da biblioteca sem precisar visitar fisicamente suas informações. Isso tem duas consequências: as métricas tradicionais das bibliotecas precisem ser repensadas, pois a quantidade de visitas e empréstimos tendem a diminuir; os usuários utilizam de serviços de biblioteca sem ter a consciência de quem é o provedor desses serviços.

Germano (2011, p. 100) diz que conhecer os concorrentes diretos dos serviços de biblioteca é uma estratégia importante para entender o valor da própria biblioteca, pois a criação de valor está associada com os serviços diferenciados, que vão ao encontro das necessidades dos usuários. Sem o adequado conhecimento sobre os produtos e serviços informacionais que o usuário dispõe, as bibliotecas correm o risco de se tornarem irrelevantes e obsoletas aos usuários. O autor credita o distanciamento dos produtos e serviços oferecidos pelas bibliotecas das necessidades dos usuários, gerando desprestígio dessas instituições, às recorrentes mudanças na indústria da informação, que permite que os usuários tenham diferentes expectativas dos serviços de informação em pouco tempo.

Alguns serviços de biblioteca, de fato, podem ser obtidos de outras formas gratuitamente. A utilização do espaço físico é um exemplo. Atualmente, a função de oferecer lugares agradáveis para estudo, pesquisa, socialização e compartilhamento de informações é totalmente substituída por espaços que oferecem uso gratuito de internet. Dessa forma, os usuários podem obter esse mesmo serviço em outros locais, como cafés, livrarias, shoppings, parques etc.

Por outro lado, alguns produtos e serviços da biblioteca precisam ser adquiridos no mercado como alternativa, como o caso de empréstimos de livros, onde o usuário pode ter acesso ao livro por meio de compra, ou caso seja o acesso a um artigo específico de uma base de dados, o usuário pode adquirir o acesso ao artigo desejado, pagando um valor por unidade. Atualmente ainda existem iniciativas na internet de disponibilização de publicações de forma gratuita, infringindo os direitos autorais. Nos dois primeiros casos, além do valor financeiro 
investido na compra de um bem que a biblioteca disponibilizava, os usuários também investem tempo, e talvez, dinheiro na locomoção até conseguir o livro ou artigo desejado. No caso, das obras disponibilizadas de forma ilegal, o usuário assume a responsabilidade de estar infringindo a lei de vários países para conseguir acesso às publicações desejadas, sem contar em todas as implicações éticas desse tipo de ação. Da mesma forma, ao abrir mão do serviço de pesquisa bibliográfica, o usuário deixa de utilizar a mão de obra especializada em fazer buscas precisas e, novamente, investe tempo até encontrar a informação desejada. Tudo isso comprova que os serviços prestados pelas bibliotecas não podem ser substituídos gratuitamente e que o valor do uso e da existência das bibliotecas podem ser medidos.

Existem ainda os casos de produtos e serviços que não podem ser encontrados no mercado, como é o caso da preservação da memória bibliográfica institucional e a preservação de obras físicas, como as obras raras. Ao tomar a decisão de fechar bibliotecas, os gestores normalmente não sabem o real valor da perda de sua memória institucional. Caso se trate de uma instituição pública, onde a memória institucional está diretamente relacionada à memória do país, o valor das informações perdidas pode ser superior. O mesmo se aplica na escolha de investir ou não na conservação de obras raras.

Diante dessa grande variedade de produtos e serviços, que podem ou não ser substituídos, cabe às bibliotecas o trabalho de comunicar ao usuário a relevância de suas atividades e assim, gerar valor sob a perspectiva do usuário. Assim, na literatura, encontramse as principais formas de agregar valor aos serviços de informação, de forma que possam ser expostos de forma qualitativa ou quantitativa, como será apresentado a seguir.

\subsection{Valor social das bibliotecas}

O valor social das bibliotecas pode ser observado nas atividades das bibliotecas públicas. Matthews (2011, p. 8) apresenta os benefícios indiretos proporcionados pelas bibliotecas públicas. Segundo o autor, as bibliotecas: ajudam no processo de alfabetização inicial, oferecendo lugares seguros para estudo, recursos complementares à escola que permite aumentar as habilidades de leitura; ajudam no desenvolvimento econômico local, a partir da geração de emprego e da disponibilização de recursos para a comunidade; ajudam no desenvolvimento de habilidades uteis para a vida profissional dos usuários, seja na formação pessoal, seja na própria utilização dos recursos tecnológicos da biblioteca para encontrar um emprego; ajudam no desenvolvimento de pequenos negócios, por meio de atividades de consultoria bibliográfica para pequenas empresas da região; ajudam a interação social e o 
compartilhamento de informações, por meio da disponibilização de seu espaço físico; e, por fim, permitem a melhoria na qualidade de vida, na satisfação pessoal e no desenvolvimento pessoal de seus usuários, por meio de todos os seus produtos e serviços e pelas atividades culturais e recreativas. Wintroub (2007, p. 1) acrescenta a essa lista a colaboração à preservação da história local, a revitalização da comunidade e o atendimento a turistas, com a disponibilização de obras em língua estrangeira.

McCallum e Quinn (2013, p. 56), ao abordarem as bibliotecas públicas na Austrália, relatam que vários estudos atestam o valor social das bibliotecas, destacando que elas fornecem:

- recursos de informação para o uso diário, para a recreação, e para apoiar a educação formal e informal e aprendizagem ao longo da vida;

- acesso ao governo e outras informações eletrônicas, disponíveis a partir de fontes de fora da biblioteca;

- informações, serviços e instalações que contribuem para o desenvolvimento da comunidade de referência;

- lugares seguros e acolhedores para o contato social, e

- acesso livre, sem restrições e equitativo aos serviços e recursos por todos os membros da comunidade.

Com a disponibilização de seus recursos, as bibliotecas públicas promovem a alfabetização e estimulam a competência informacional da população, estimulam a iniciativa e aumentam a qualidade de vida, introduzem e desenvolvem habilidades no uso de tecnologia da informação e fomentam a pesquisa.

A valoração de bibliotecas a partir de métodos qualitativos não se restringe apenas às bibliotecas públicas. $\mathrm{O}$ valor das bibliotecas nacionais, por exemplo, é representado pela sua função de preservar a história, a memória e a cultura nacional. Marshall et al. (2013, p. 38) avaliam o impacto dos serviços de informação no cuidado a pacientes em bibliotecas hospitalares. A biblioterapia é constantemente apontada como grande colaboradora na recuperação de pacientes diante da atuação de bibliotecários, pedagogos e psicólogos em hospitais, escolas e asilos, conforme estudos de Souza, Santos e Ramos (2013) e Caldin (2001, p. 32).

No âmbito das bibliotecas escolares, Campello (2010, p. 7) apresenta o valor das bibliotecas públicas na construção do conhecimento nas escolas e no desenvolvimento intelectual dos alunos, ao mesmo tempo em que apresenta as características básicas para que essas bibliotecas consigam oferecer produtos e serviços adequados à comunidade escolar. 
Garcez (2006) enfatiza a vantagem competitiva que as bibliotecas escolares fornecem aos alunos diante da economia da informação.

As bibliotecas institucionais possuem produtos e serviços que contribuem no processo de redução de incerteza e produzem insumos de valor estratégico, colaborando para que suas instituições possuam vantagem competitiva diante de outras do mercado. A informação deve ser considerada como um diferencial na instituição, pois ela pode proporcionar alternativas de melhoria nos processos, fortalecendo a tomada de decisões. (SANTOS; MELO, 2015, p. 105). A gestão de sistemas de informação, conhecimento e inteligência para instituições é um tema que cresce exponencialmente.

A quantidade de produções no campo de valoração econômica de bibliotecas ainda é muito discreta, pois grande parte dos estudos está voltada para o valor social, sobretudo nas discussões sobre bibliotecas públicas (MCCALLUM; QUINN, 2004, p. 65). Porém, mesmo com a apresentação de dados e resultados do valor das bibliotecas públicas para a sociedade, McKerracher (2008, p. 3) enfatiza o fato de que diante da alocação de recursos públicos, as bibliotecas perdem prioridades diante de áreas como educação, saúde e serviços de emergência.

Para solucionar a questão em torno da contribuição econômica das bibliotecas, as bibliotecas começaram a utilizar metodologias de valoração econômica, que serão apresentadas no estudo de caso a seguir. 


\section{ESTUDO DE CASO: VALORAÇÃO ECONÔMICA DE BIBLIOTECAS}

\subsection{Métodos e procedimentos}

Esse estudo é uma pesquisa descritiva, baseada em uma revisão sistemática de bibliografia. Trata-se de um estudo bibliométrico, ou seja, esse estudo compila a produção bibliográfica referente ao tema, recuperada de acordo com critérios de pesquisa préestabelecidos, que são apontados nesta seção.

Para fazer um panorama das publicações relacionadas à valoração econômica de bibliotecas, foram pesquisados livros, artigos de periódicos, relatórios de pesquisa e trabalhos acadêmicos nas seguintes bases de dados:

$\underline{\text { Portal da Capes }}^{1}$ - o portal da Capes é o maior portal de pesquisa científica do Brasil. Foi utilizada a meta-busca, a fim de recuperar títulos em todas as bases de dados disponibilizadas no portal.

LISTA $^{2}$ - A Library, Information Science and Technology Abstracts é uma base de dados pertencente à empresa Ebsco que disponibiliza resumos e textos completos de pesquisas relacionadas à Ciência e Tecnologia da Informação.

Ebrary ${ }^{3}$ - A Ebrary é uma base de dados de livros eletrônicos de assuntos diversos, pertencente à empresa Proquest.

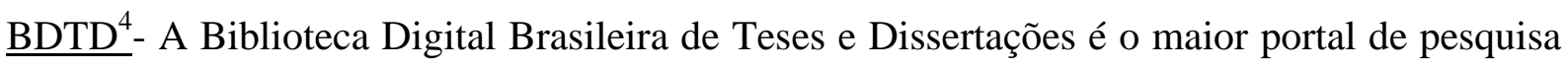
em produções acadêmicas do Brasil.

$\underline{\text { Scielo }^{5}}$ - A Scientific Eletronic Lybrary Online é a maior biblioteca de produções científicas disponibilizadas em domínio público em língua portuguesa e espanhola.

Google Acadêmico ${ }^{6}-$ O Google Acadêmico permite fazer pesquisas em fontes específicas relacionadas à produção científica.

\footnotetext{
${ }^{1}$ Disponível em: http://www.periodicos.capes.gov.br/ (acesso restrito).

${ }^{2}$ Disponível em: http://web.a.ebscohost.com/ehost/search/basic?sid=96863ff8-85cf-4c79-b6c1b2bb7af42a33\%40sessionmgr4006\&vid=0\&hid=4112 (acesso livre)

${ }^{3}$ Disponível em: http://site.ebrary.com/lib/univbrasilia/home.action (acesso restrito)

${ }^{4}$ Disponível em: http://bdtd.ibict.br/vufind/ (acesso livre)

${ }^{5}$ Disponível em: $\underline{\text { http://www.scielo.br/?lng=pt (acesso livre) }}$

${ }^{6}$ Disponível em: https://scholar.google.com.br/ (acesso livre)
} 
As pesquisas foram feitas por palavras-chave relacionadas ao tema. Foram utilizados os seguintes termos Valoração Econômica, Valor Econômico, Métodos de valoração. Esses termos foram qualificados com as seguintes palavras-chave: Bibliotecas, Serviços de informação e Unidades de Informação.

As pesquisas foram feitas em três idiomas: português, inglês e espanhol e a margem temporal utilizada para essa pesquisa foi de 1990 a 2016.

A elaboração desse estudo foi divida em duas partes: a primeira diz respeito à leitura e à elaboração de resumo das publicações recuperadas. Essa parte compreende ainda a elaboração de quadro-resumo e breve análise. A segunda parte diz respeito à indicação de quais são os métodos utilizados na literatura que se aplicam à Biblioteca do Instituto de Pesquisa Econômica Aplicada. Essa biblioteca foi escolhida devido ao potencial de disponibilizar informações de caráter estratégico para o país, à medida que oferece suporte às pesquisas que avaliam e propõem a adoção de políticas públicas.

No total, foram utilizados 39 documentos, sendo 36 em língua inglesa, 3 em língua espanhola e nenhum texto em língua portuguesa, conforme pode ser observado no gráfico 1.

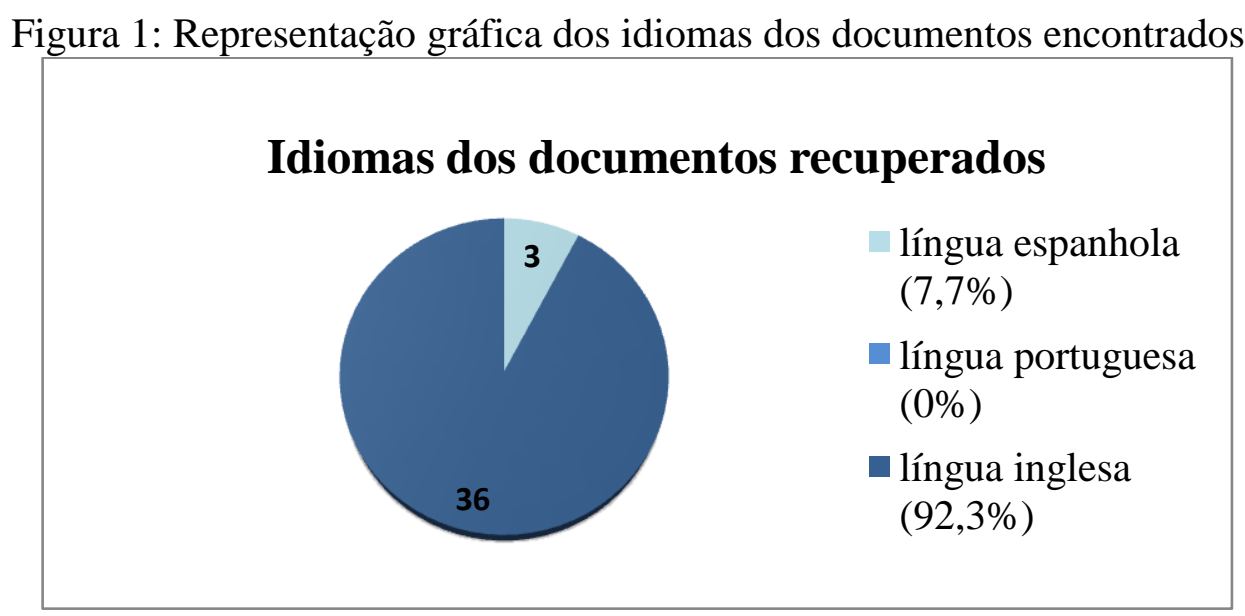

Fonte: Elaborado pelo autor

Entre os documentos recuperados na busca e utilizados para essa dissertação, encontram-se 3 livros, 26 artigos e 10 relatórios de pesquisa. 
Figura 2: Representação gráfica dos tipos de documentos recuperados

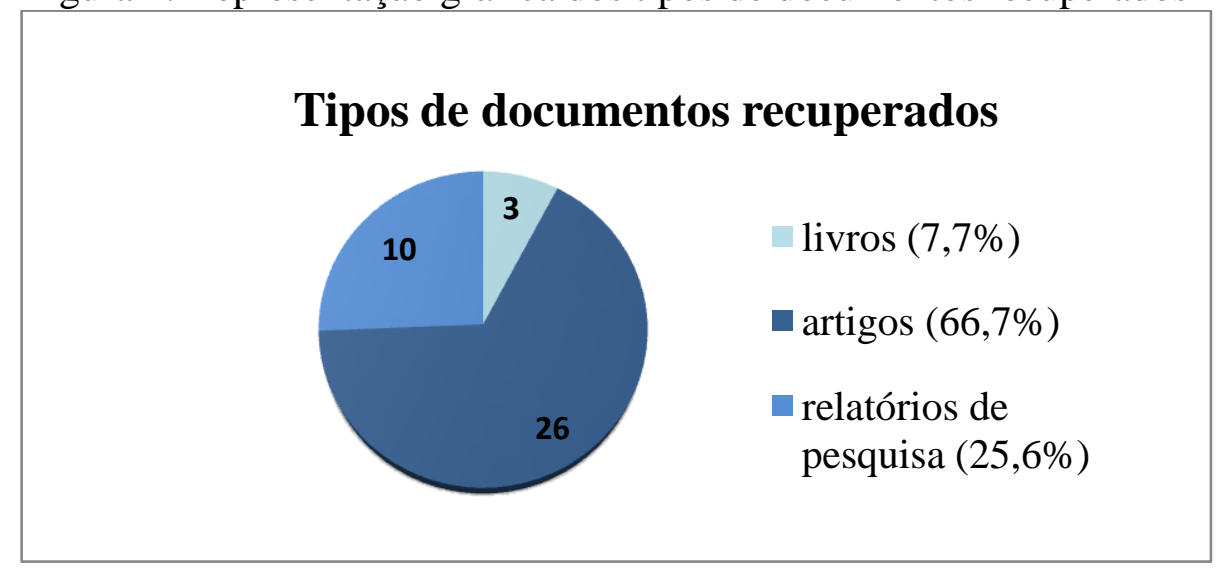

Fonte: Elaborado pelo autor

\subsection{Valoração econômica de bibliotecas}

No Quadro 1, encontram-se as principais informações extraídas dos textos consultados e organizadas por ordem cronológica de publicação. 
Quadro 1: Resumo dos dados recuperados na literatura de valoração econômica de bibliotecas

\begin{tabular}{|c|c|c|c|c|c|}
\hline Ano & Autores & Local & Método & $\begin{array}{c}\text { Tipo de } \\
\text { biblioteca } \\
\text { avaliada }\end{array}$ & $\begin{array}{c}\text { Produto/ } \\
\text { serviço } \\
\text { que está } \\
\text { sendo } \\
\text { valorado } \\
\end{array}$ \\
\hline 1995 & Keyes & EUA & $\begin{array}{l}\text { Valor do tempo/ Análise de } \\
\text { Custo benefício/ Avaliação } \\
\text { de impacto econômico }\end{array}$ & Especializada & Biblioteca \\
\hline 1999 & $\begin{array}{l}\text { Harless e } \\
\text { Allen }\end{array}$ & EUA & VC, mas somente DAP & Universitária & $\begin{array}{l}\text { Serviço de } \\
\text { Referência }\end{array}$ \\
\hline 1999 & Holt et al. & EUA & $\mathrm{VC} / \mathrm{ACB}$ & Pública & $\begin{array}{c}\text { Serviços } \\
\text { da } \\
\text { biblioteca } \\
\text { em geral } \\
\end{array}$ \\
\hline 2002 & $\begin{array}{c}\text { Aabo e } \\
\text { Adunson }\end{array}$ & Noruega & $\mathrm{VC}$ & Pública & Biblioteca \\
\hline 2004 & Aabo & Noruega & VC/Método de Elicitação & Pública & Biblioteca \\
\hline 2004 & $\begin{array}{l}\text { Griffiths, } \\
\text { king e } \\
\text { Lynch }\end{array}$ & EUA & $\begin{array}{c}\text { VC/RI/Avaliação do } \\
\text { impacto econômico/ Valor } \\
\text { de Mercado/ Custo total de } \\
\text { serviços e produtos }\end{array}$ & Pública & Biblioteca \\
\hline 2004 & $\begin{array}{l}\text { Pung, Elwes } \\
\text { e Marks }\end{array}$ & $\begin{array}{l}\text { Reino } \\
\text { Unido }\end{array}$ & $\mathrm{VC}$ & Nacional & $\begin{array}{c}\text { Acesso às } \\
\text { coleções } \\
\text { da sala de } \\
\text { leitura/ } \\
\text { serviços } \\
\text { bibliográfi } \\
\text { cos e } \\
\text { documentá } \\
\text { rios } \\
\text { remotos/ev } \\
\text { entos/expo } \\
\text { sições }\end{array}$ \\
\hline 2005 & Aabo & Noruega & $\mathrm{VC} / \mathrm{ACB}$ & Pública & Biblioteca \\
\hline 2005 & Aabo (b) & Noruega & $\mathrm{VC}$ & Pública & Biblioteca \\
\hline 2005 & SLISUSC & EUA & $\begin{array}{l}\text { VC/RI/Avaliação do impacto } \\
\text { econômico/ Valor de } \\
\text { Mercado/ Custo total de } \\
\text { serviços e produtos }\end{array}$ & Pública & Biblioteca \\
\hline 2006 & $\begin{array}{l}\text { Grifiths et } \\
\text { al. }\end{array}$ & EUA & $\begin{array}{l}\text { VC/RI/Avaliação do impacto } \\
\text { econômico/ Valor de } \\
\text { Mercado/ Custo total de } \\
\text { serviços e produtos/REMI }\end{array}$ & Pública & Biblioteca \\
\hline 2006 & Kamer & EUA & ACB/Análise de impacto & Pública & Biblioteca \\
\hline 2006 & LDF & EUA & $\begin{array}{l}\text { VC/RI/Avaliação do impacto } \\
\text { econômico/ Valor de } \\
\text { Mercado/ Custo total de } \\
\text { serviços e produtos }\end{array}$ & Pública & Biblioteca \\
\hline
\end{tabular}




\begin{tabular}{|c|c|c|c|c|c|}
\hline Ano & Autores & Local & Método & $\begin{array}{c}\text { Tipo de } \\
\text { biblioteca } \\
\text { avaliada }\end{array}$ & $\begin{array}{l}\text { Produto/ } \\
\text { serviço } \\
\text { que está } \\
\text { sendo } \\
\text { valorado }\end{array}$ \\
\hline 2007 & Elliot et al. & EUA & $\begin{array}{c}\text { ACB/Análise de impacto/ } \\
\text { Matriz de usuário } \\
\text { Serviço/Análise de } \\
\text { Excedente de } \\
\text { Consumo/Valor do Tempo }\end{array}$ & Pública & Biblioteca \\
\hline 2007 & IBRC & EUA & $\begin{array}{c}\text { VC / RI/ Avaliação do } \\
\text { impacto econômico/ Valor } \\
\text { de Mercado/ Custo total de } \\
\text { serviços e produtos }\end{array}$ & Pública & Biblioteca \\
\hline 2007 & Kotch & EUA & ACB/ Análise de impacto & Pública & Biblioteca \\
\hline 2007 & Wagman & Noruega & $\begin{array}{c}\mathrm{ACB} / \text { Análise de } \\
\text { impacto/utiliza o VC antes } \\
\text { de aplicar a ACB }\end{array}$ & Pública & Biblioteca \\
\hline 2007 & $\begin{array}{l}\text { NorthStar } \\
\text { Economics }\end{array}$ & EUA & $\begin{array}{l}\text { VET medido a partir da } \\
\text { soma dos valores de } \\
\text { mercado/Impacto } \\
\text { Econômico }\end{array}$ & Pública & Biblioteca \\
\hline 2007 & White & EUA & RI & $\begin{array}{l}\text { Qualquer } \\
\text { biblioteca }\end{array}$ & $\begin{array}{l}\text { Serviços e } \\
\text { bens } \\
\text { informacio } \\
\text { nais em } \\
\text { geral } \\
\end{array}$ \\
\hline 2008 & $\begin{array}{l}\text { Arts Council } \\
\text { England }\end{array}$ & $\begin{array}{l}\text { Reino } \\
\text { Unido }\end{array}$ & $\begin{array}{c}\text { Análise do impacto } \\
\text { econômico/Impacto baseado } \\
\text { no local/ VET/ ACB }\end{array}$ & Pública & Biblioteca \\
\hline 2008 & Chung & $\begin{array}{l}\text { Coreia } \\
\text { do Sul }\end{array}$ & VC adaptado & Pública & Biblioteca \\
\hline 2008 & Luther & EUA & $\begin{array}{l}\text { RI baseado em modelo } \\
\text { econométrico de citações }\end{array}$ & Universitária & Biblioteca \\
\hline 2008 & $\begin{array}{l}\text { McKerrache } \\
\text { r }\end{array}$ & $\begin{array}{c}\text { Austráli } \\
\text { a }\end{array}$ & $\begin{array}{l}\text { VC/Valor de Mercado/RI/ } \\
\text { Contribuição Econômica } \\
\text { Direta }\end{array}$ & Pública & Biblioteca \\
\hline 2008 & MLA & EUA & RI & Pública & Biblioteca \\
\hline 2009 & Aabo & Noruega & $\begin{array}{l}\mathrm{RI} / \mathrm{ACB} / \text { Análise de } \\
\text { regressão multivariada }\end{array}$ & Pública & Biblioteca \\
\hline 2009 & Steffen et al. & EUA & $\begin{array}{l}\text { VC/RI/Avaliação do } \\
\text { impacto econômico/ Valor } \\
\text { de Mercado/ Custo total de } \\
\text { serviços e produtos }\end{array}$ & Pública & Biblioteca \\
\hline
\end{tabular}




\begin{tabular}{|c|c|c|c|c|c|}
\hline Ano & Autores & Local & Método & $\begin{array}{l}\text { Tipo de } \\
\text { biblioteca } \\
\text { avaliada }\end{array}$ & $\begin{array}{l}\text { Produto/ } \\
\text { serviço } \\
\text { que está } \\
\text { sendo } \\
\text { valorado } \\
\end{array}$ \\
\hline 2010 & Cervone & EUA & $\mathrm{ACB}$ & Pública & $\begin{array}{c}\text { Biblioteca } \\
\text { Digital }\end{array}$ \\
\hline 2010 & $\begin{array}{l}\text { Lee, Chung } \\
\text { e Jung }\end{array}$ & $\begin{array}{l}\text { Coreia } \\
\text { do Sul }\end{array}$ & $\begin{array}{l}\text { VC com ênfase na DAA } \\
\text { para reduzir warm glow }\end{array}$ & Pública & Biblioteca \\
\hline 2010 & Tenopir & EUA & $\begin{array}{l}\text { RI, baseado em modelo } \\
\text { econométrico de citações }\end{array}$ & Universitária & $\begin{array}{l}\text { Coleção } \\
\text { de } \\
\text { Periódicos } \\
\text { Digitais }\end{array}$ \\
\hline 2011 & BBER & EUA & $\begin{array}{c}\text { VC/RI/Avaliação do } \\
\text { impacto econômico/ Valor } \\
\text { de Mercado/Custo total de } \\
\text { serviços e produtos/SROI }\end{array}$ & Pública & Biblioteca \\
\hline 2011 & Matthews & $\begin{array}{l}\text { Estados } \\
\text { Unidos }\end{array}$ & RI/ VC/VET & Pública & Biblioteca \\
\hline 2012 & $\begin{array}{l}\text { Guerrero, } \\
\text { Rodriguez e } \\
\text { Garcia }\end{array}$ & Cuba & $\begin{array}{l}\text { Valor Econômico Básico } \\
\text { Anual/Valor de depreciação }\end{array}$ & Especializada & $\begin{array}{l}\text { Coleção } \\
\text { de } \\
\text { Periódicos } \\
\text { Impressos } \\
\end{array}$ \\
\hline 2012 & Ko et al. & $\begin{array}{l}\text { Coreia } \\
\text { do Sul }\end{array}$ & VC/RI & Pública & Biblioteca \\
\hline 2012 & Lee e chung & $\begin{array}{l}\text { Coreia } \\
\text { do Sul }\end{array}$ & $\begin{array}{l}\text { VC/VET, com ênfase no } \\
\text { valor altruísta }\end{array}$ & Pública & Biblioteca \\
\hline 2013 & $\begin{array}{l}\text { Consejo de } \\
\text { Cooperación } \\
\text { Bibliotecária }\end{array}$ & Espanha & $\begin{array}{l}\text { Calculo de Valor Estimado } \\
\text { e VET (VC e Valor de } \\
\text { Mercado)/ Benefício } \\
\text { Econômico Estimado (RI e } \\
\text { RSI)/ Atividade Econômica } \\
\text { Estimada (Valor } \\
\text { Acrescentado e Impacto } \\
\text { Econômico) }\end{array}$ & $\begin{array}{l}\text { Nacional e } \\
\text { Pública }\end{array}$ & Biblioteca \\
\hline 2013 & Mcintosh & EUA & $\mathrm{VC} / \mathrm{ACB}$ & Pública & Biblioteca \\
\hline 2014 & $\begin{array}{l}\text { Hájek e } \\
\text { Stjskal }\end{array}$ & $\begin{array}{l}\text { Repúbli } \\
\text { ca } \\
\text { Tcheca }\end{array}$ & $\begin{array}{l}\text { VC, sendo A DAP com } \\
\text { dinheiro do próprio bolso e } \\
\text { a DAA a partir dos valores } \\
\text { incluídos nos impostos já } \\
\text { pagos/ Custo de Viagem }\end{array}$ & Pública & Biblioteca \\
\hline 2014 & $\begin{array}{l}\text { Hernon, } \\
\text { Dungan e } \\
\text { Mathews }\end{array}$ & EUA & $\mathrm{ACB}=\mathrm{RI} / \mathrm{VET}$ & Pública & Biblioteca \\
\hline 2014 & Yañez & Espanha & VC/RI/Impacto Econômico & Pública & Biblioteca \\
\hline
\end{tabular}




\begin{tabular}{|c|c|c|c|c|c|}
\hline Ano & Autores & Local & Método & $\begin{array}{c}\text { Produto/ } \\
\text { Tipo de } \\
\text { biblioteca } \\
\text { avaliada } \\
\text { serviço } \\
\text { que está } \\
\text { sendo } \\
\text { valorado }\end{array}$ \\
\hline 2015 & $\begin{array}{c}\text { Bano e } \\
\text { Haridasan }\end{array}$ & Índia & VC (apenas DAP)/ ACB & Universitária & $\begin{array}{c}\text { Coleção } \\
\text { de } \\
\text { Periódicos } \\
\text { Impressos } \\
\text { e Digitais }\end{array}$ \\
\hline 2015 & $\begin{array}{c}\text { Shepherd, } \\
\text { Vardy e } \\
\text { Wilson } \\
\text { Stejskal e } \\
\text { Hajek }\end{array}$ & $\begin{array}{c}\text { Repúbli } \\
\text { ca } \\
\text { Tcheca }\end{array}$ & VC/Valor do Tempo & Pública & $\begin{array}{c}\text { Produtos } \\
\text { circuláveis }\end{array}$ \\
\hline
\end{tabular}

Fonte: Elaborado pelo autor

Siglas: Valoração Contingente (VC), Retorno de Investimento (RI), Retorno Social de Investimento (RSI), Disposição a pagar (DAP), Valor Econômico Total (VET), Análise de Custo-Benefício (ACB).

\subsubsection{Revisão de literatura}

A pesquisa de como avaliar e a aplicação de métodos de valoração econômica de bibliotecas se desenvolveram de forma conjunta, sendo que em alguns casos, a discussão sobre a aplicabilidade e o sucesso de determinados métodos somente aconteceu após a publicação dos resultados de bibliotecas que utilizaram esses métodos. Por esse motivo, serão apresentados a seguir os estudos que indicam ou comunicam os resultados da aplicação de métodos de valoração em ordem cronológica de publicação.

Keyes (1995, p. 172) analisa estudos feitos em bibliotecas especializadas e destaca o uso de métodos que valoram o tempo economizado pelo usuário, a produtividade e o custo-benefício. Após a análise, a autora sugere quatro passos para a valoração de bibliotecas especializadas. Primeiro, e mais importante, todos os dados de custo para operar serviços de informação que podem ser extraídos, devem ser extraídos. Em segundo lugar, recolher estimativas de usuário do valor dos serviços de biblioteca benéficos ou documentos deve ser parte da rotina dos serviços de informação. Em quantidade suficiente, esses dados irão atingir um nível significativo. Em terceiro lugar, o impacto da biblioteca especializada deve ser registrado. Todos os casos positivos de impacto devem ser contabilizados, mensurável em termos qualitativos, e contável, se não for facilmente convertidos monetariamente. Em quarto lugar, analisar o custo e benefício informação recolhida e 
determinar relações custo-benefício. Decidir se a informação deve ser apresentada por usuário, por departamento ou por organização, e apoiar esses números com as informações de impacto positivo, para chegar a um valor da biblioteca especial para a instituição a qual pertence.

Harless e Allen (1999 apud AABO; STRAND, 2004, p. 354) utilizaram a valoração contingente como método para avaliar o serviço de referência de uma biblioteca universitária, a James Branch Cabell Library at Virginia Commonwealth University. Não foi elicitado nenhum valor de não-uso e o altruísmo não foi considerado importante.

Holt et al. (1999 apud AABO; STRAND, 2004, p. 354) utilizaram a valoração contingente para avaliar três serviços da Biblioteca Pública de St. Louis, por meio de análise de custo-benefício. Nesse estudo foram percebidos os valores de uso e os valores para a sociedade, indicando a existência e a importância dos valores de não-uso, inclusive o altruísmo.

Aabo e Adunson (2002, p. 12) recomendam a valoração contingente para medir bibliotecas públicas, pois é o único método que parte da pressuposição da racionalidade dos agentes e avalia também o valor de não uso.

Aabo e Strand (2004, p. 353) relatam a importância de medir o não-uso das bibliotecas. Os autores usam o conceito de valor econômico total, proveniente da Economia para a valoração de bens públicos. Os autores explicam também que existem três tipos de valor para o não-uso da biblioteca: o valor de existência, valor de legado e valor motivado pelo altruísmo. Aabo (2004, p. 177) aplica um método de valoração contingente para as bibliotecas públicas, com métodos inovadores de elicitação.

Griffiths, King e Lynch (2004) calcularam o retorno dos investimentos de impostos aplicados no Estado da Florida, dando início a um processo de valoração de bibliotecas públicas por estados norte-americanos, que foi seguido pelos diversos estados, como: Carolina do Sul (SLISUSC, 2005), Pennsylvania (GRIFFITHS et al., 2006), Ohio (LDF, 2006), Indiana (IBRC, 2007), Colorado (STEFFEN et al., 2009) e Minesota (BBER, 2011). Em todos os casos foram utilizados múltiplos métodos para inferir o valor econômico de cada rede de bibliotecas e todos utilizaram esse valor para calcular o retorno de investimento da biblioteca. Todos os casos usaram medidas conservadoras que priorizam os benefícios diretos da biblioteca, pois são fáceis de medir e de justificar suas escolhas, caso seja necessário. Assim, os relatórios de cada biblioteca medem o valor e o impacto para suas devidas comunidades por meio de valoração contingente (com perguntas relacionadas apenas à disposição a pagar), valor de produtos e serviços no mercado, estimativa de custo dos 
produtos e serviços da biblioteca, gastos da biblioteca e dos usuários na comunidade. Para calcular o impacto econômico das bibliotecas no estado da Pennsylvania, foi utilizado um modelo chamado REMI, que indica os efeitos diretos, indiretos e induzidos no produto regional bruto. $\mathrm{O}$ estado de Minnesota utiliza uma medida menos conservadora ao medir o retorno social de investimento. O resultado do retorno de investimento foi positivo, sendo que o menor retorno foi calculado no estado da Indiana, com \$2,38 dólares para cada \$1 dólar investido.

Pung, Elwes e Marks (2004, p. 83) relatam a existência de dois métodos para valoração econômica de bibliotecas nacionais: Análise do Impacto Macroeconômico e Análise de Excedente de Consumo. O primeiro método mede variáveis macroeconômicas como contribuição ao lucro, faturamento e emprego. O segundo mede o bem-estar econômico, por meio dos benefícios que os consumidores desfrutam, comparado pelo preço que eles pagam. A análise de excedente de consumo foi selecionada por valorizar bens que não se traduzem facilmente sobre variáveis macroeconômicas. Para medir o excedente de consumo foram listados dois métodos: A preferência revelada e a valoração contingente. Como a preferência revelada pressupõe a existência de um mercado substituto, o método escolhido foi a valoração contingente. Na Biblioteca Nacional Britânica foram valorados os seguintes serviços: acesso às coleções da sala de leitura, serviços bibliográficos e documentários remotos, eventos e exposições. Foram valorados também a existência e a opção de uso de indivíduos da sociedade. Os resultados indicam que, na média, os cidadãos estão dispostos a pagar o dobro do que eles já pagam indiretamente por meio de impostos. O estudo também revelou que a biblioteca gera um valor quatro vezes maior que o investimento do governo. A análise de retorno de investimento informou um retorno de 4,4 libras para cada libra investida.

Aabo (2005, p. 492) realiza a primeira valoração das bibliotecas públicas em nível nacional, por meio do método de valoração contingente e complementa o estudo com uma análise de custo benefício, cujo resultado foi 1:4. No mesmo ano, Aabo (2005b, p. 3) fez outra pesquisa em nível nacional com valoração contingente. O diferencial dessa valoração se dá no fato de que, durante as entrevistas, a disposição a pagar era medida com o dinheiro alocado dos impostos e a disposição a aceitar era medida com dinheiro do próprio bolso. As pessoas pagariam menos com o próprio bolso, pois acreditam que possuem direitos sobre isso.

Kamer (2006, p. 1) destaca dois métodos usados para valorar as bibliotecas públicas de Nova York. O primeiro método compara o valor dos serviços diretos prestados pela biblioteca com o dinheiro dos impostos usados para mantê-la. O segundo método estima que o impacto econômico das despesas operacionais e de capital feitas pela biblioteca. Foram 
valorados vários serviços, incluindo as transações de circulação de referência, as coleções, as programações e os recursos eletrônicos. O uso dos serviços foi avaliado por meio do relatório anual de 2005. Todos os serviços foram analisados com base no preço de mercado e valor total do serviço da biblioteca foi avaliado por meio da multiplicação do numero de todos os usuários pelo custo individual que cada um teria ao adquirir esses serviços no mercado. A análise de custo benefício foi feita com a comparação desse valor total da biblioteca com o montante recebi pelos governos local e federal.

Elliot et al. (2007, p. 11) defendem que a abordagem mais apropriada para medir o valor de uma biblioteca pública é a Avaliação de Custo-Benefício. Para eles, apresentar os benefícios é uma atividade que deve ser feita com cuidado, por conta dos vieses dos métodos de valorar os benefícios indiretos. Os autores apresentam a Avaliação de Impacto, medida por meio da Análise do Efeito Multiplicador, mas ressaltam que poucas bibliotecas possuem perfil adequado para utilizar esse método, pois para isso, as bibliotecas deveriam ter serviços exclusivos que impedissem os usuários locais de irem a outras bibliotecas em busca do mesmo serviço e que atraísse muitos usuários de outras regiões. Para medir os benefícios das bibliotecas, os autores propõem uma Matriz de Usuário-Serviço (MUS), que divide os tipos de usuário de acordo com os serviços disponibilizados. Como alternativa, são apresentados a Análise de Excedente de consumo (AEC), a Valoração contingente (VC) e a Valoração por Tempo (VT). No excedente de consumo, é medida a disposição a pagar dos usuários por um produto ou serviço que pode ser encontrado também no mercado. Na valoração contingente, é indicado o uso apenas da disposição a pagar, pois a disposição a aceitar, segundo os autores, pode gerar resultados questionáveis e imprecisos. Na valoração por tempo são medidos o tempo e o esforço dos usuários na visita à biblioteca, sendo chamado pelos economistas como custos transacionais. Porém, os autores salientam a dificuldade de avaliar o tempo de acordo com os diferentes tipos de usuários e, portanto, desencorajam o uso desse método em comparação com os outros.

A NorthStar Economics (2007, p. 7), apresenta os resultados da análise de retorno de investimento feita nas bibliotecas do Estado de Wisconsin. Nesse estudo, foi avaliado o impacto econômico por meio da contribuição econômica direta. Esse valor foi medido com a soma do total dos gastos da biblioteca, dos funcionários e dos usuários na comunidade. $\mathrm{O}$ valor econômico total foi avaliado por meio da soma do valor de mercado de alguns serviços. Além disso, foi estimado que cada usuário teria que pagar \$205,00 dólares para ter acesso aos mesmos serviços mensalmente no mercado. O retorno de investimento mostrou que existe um valor estimado de \$4,06 dólares para cada $\$ 1$ dólar investido. Nesse relatório ainda é 
considerado que o valor da biblioteca é maior, tendo em vista que nem todos os serviços e produtos foram valorados, devido à falta de métodos apropriados. $\mathrm{O}$ autor ainda salienta que $\mathrm{o}$ resultado desse estudo está de acordo com os resultados apresentados pela valoração das bibliotecas públicas de outros estados, apresentados anteriormente.

Kotch (2007 apud Hajec; Stejskal, 2015, p. 45) utilizou a Análise de Custo Benefício, juntamente com métodos de analogia de mercado e avaliação de impacto econômico indireto para medir economicamente o valor das bibliotecas do Estado de Vermont, nos Estados Unidos da América. O impacto econômico exato foi estimado como a soma dos custos totais das bibliotecas para o período monitorado, suas rendas não-fiscais e os valores dos serviços individuais (empréstimos, serviços de referência, etc.). O impacto econômico indireto foi então especificado como uma soma dos salários pagos, os custos de construção, os custos de equipamentos comprados, etc. A relação custo-benefício resultante foi de 1: 6,96 .

Wagman (2007 apud AABO, 2009, p. 314) conduz uma meta-análise, na qual conclui que duas abordagens compreendem a maioria dos estudos de valoração de biblioteca: Análise de Custo-Benefício e Análise do impacto econômico. O autor diferencia as duas abordagens da seguinte forma: as análises de custo-benefício utilizam diferentes métodos para alcançar os benefícios das bibliotecas, como as analogias com o mercado, as preferências reveladas e as preferências declaradas. Entre as preferências declaradas, o método de valoração contingente é o mais utilizado. As análises de impacto medem o spin-off e os efeitos multiplicadores das despesas da biblioteca, incluindo gastos com manutenção e construção de edifícios da biblioteca, livros equipamentos, além do salário dos servidores que gastam na comunidade.

White (2007, p. 7) diz que a aplicação do retorno de investimento em bibliotecas tem sido feita de forma pouco efetiva. $\mathrm{O}$ autor diz que esse método deve ser usado de outras formas, a fim de conseguir gerar dados mais precisos e confiáveis. Assim, ele afirma que deve ser usado de três formas. A primeira forma trata do uso em atividades e serviços pequenos, pois a valoração da biblioteca como um todo não representa adequadamente o valor de cada atividade. A segunda forma diz respeito ao uso do método pra avaliar as atividades de dentro da biblioteca, como serviços de manutenção, marketing, impressão etc. A terceira forma trata do uso de retorno de investimento para avaliar o capital intangível da biblioteca, bem como os serviços intangíveis prestados pela biblioteca, como capital intelectual, o capital humano, a fidelidade à marca, o capital de relacionamento com clientes, gestão do conhecimento etc. 
O estudo feito pela Arts Council England (2008, p. 14) apresenta três classificações dos tipos de valoração usados para bibliotecas públicas, as quais são chamadas do texto de 'hipóteses'. A primeira trata da valoração do Impacto Econômico da biblioteca na comunidade, tendo como parâmetro as vantagens que a atuação da biblioteca pode trazer para a economia local. A segunda, do Impacto Baseado no Local onde a biblioteca se encontra fisicamente, tendo como parâmetro os benefícios que a estrutura física da biblioteca pode trazer para a comunidade. A terceira, por sua vez, trata do Valor Econômico Total (VET) e da Análise de custo-benefício (ACB) das bibliotecas.

Chung (2008, p. 71) apresenta três vieses que podem ocorrer nos questionários de valoração contingente. O primeiro viés, denominado yea-saying, trata da possibilidade do individuo dizer sempre sim para as questões e superestimar o valor. O segundo viés é denominado protest answers, cuja característica é a possibilidade de não responder ou de escolher duas opções concorrentes. O terceiro viés é chamado de information bias e representa a possibilidade do respondente não apresentar uma resposta válida, por conta do desconhecimento dos serviços de bibliotecas e da valoração hipotética deles. A partir da adoção de padrões fixos para as questões, o autor sugere uma adaptação na forma de mensurar os valores da valoração contingente. A aplicação desse método é feita na Biblioteca Pública de Jungrang, em Seul - Coreia.

Luther (2008, p. 8), após observar os métodos existentes de valoração, preferiu adaptar um modelo utilizado em bibliotecas especializadas e aplicar na biblioteca da Universidade de Illinois. O método utilizado nas bibliotecas especializadas utilizava os seguintes dados: a) o tempo economizado pelos usuários; b) o dinheiro economizado pelos usuários; e c) o retorno econômico gerado pelo uso da biblioteca. O método adotado pela autora calcula o retorno de investimento com base nas citações feitas pelo corpo docente em projetos que conseguiram financiamento. O uso de recursos da biblioteca para criar projetos que ganham financiamentos para as pesquisas implica na importância e no valor que a biblioteca possui para a universidade. O resultado da pesquisa mostra uma proporção de $\$ 4,38$ para cada dólar investido na biblioteca. A autora salienta que esse modelo somente é possível de ser utilizado em instituições com a mesma natureza de pesquisa. Esse método também e indicado por Tenopir (2010, p. 39) para valorar assinaturas de periódicos eletrônicos, mas a autora enfatiza que, tendo em vista que esse não é o único produto/serviço da biblioteca, outros métodos devem ser utilizados para complementar o trabalho de valoração.

McKerracher (2008, p. 5), ao fazer uma meta-análise das publicações sobre valoração em bibliotecas públicas, classificou os métodos em quatro categorias, às quais 
chamou de 'caminhos-chave para medir o valor de bibliotecas'. O primeiro método citado foi a Valoração Contingente (VC), onde são medidas as disposições a pagar e a aceitar, além de medir o quanto o usuário está disposto a investir tempo/dinheiro e o quanto ele teria que pagar por alternativas, caso existam. O segundo método é chamado de Contribuição Econômica Direta (CED), que mede o quanto a biblioteca agrega à comunidade em termos de construções públicas, aquisições etc. O terceiro método é denominado Valor de Mercado (VM), que mede o custo de conseguir os produtos e serviços em outras fontes, desde que elas existam. $\mathrm{O}$ quarto método se chama Retorno de Investimento (RI) que, segundo o autor, utiliza alguns métodos anteriores da seguinte maneira: $(\mathrm{CED}+\mathrm{MV}) / \mathrm{n}^{\circ}$ usuários $=$ contribuição econômica per capita (CEC). Assim, RI=CEC - Imposto per capita.

Entre os métodos usados para valoração de museus, bibliotecas e arquivos, a MLA (2008, p. 15) enfatiza que os métodos mais adequados são análise do efeito multiplicador, análise de custo-benefício, valoração contingente, custo-efetividade e retorno de investimento, sendo esse ultimo o mais apropriado para o caso específico de bibliotecas. Deve-se observar que entre os métodos que foram descartados, estavam presentes o método dos preços hedônicos e a valoração do mercado, que costumam ser usados para o meio ambiente. Outro ponto que deve ser observado é que, apesar de ter sido apresentado como método independente, o retorno de investimento é comumente usado em complementação a outros métodos.

Aabo (2009, p. 313) elabora uma meta-análise sobre estudos de valoração de bibliotecas que utilizam Retorno de Investimento e Análise de Custo-Benefício. Nesse estudo, são apresentados casos de valoração em diversos países, incluindo Suécia, Austrália, Reino Unido e Nova Zelândia. Os resultados apresentados indicam uma grande carência de estudos de valoração econômica de bibliotecas escolares, especializadas, nacionais e universitárias e, portanto, a autora sugere que mais estudos sejam feitos nessas áreas.

Stephen et al. (2009, p. 4) relatam o estudo de caso feito nas bibliotecas públicas do Estado do Colorado, nos Estados Unidos. O método que eles alegam ter utilizado foi a valoração contingente, mas os questionários ainda incluíam questões de outros métodos, incluindo avaliação de impacto. As perguntas estavam relacionadas como o custo de conseguir os mesmos produtos e serviços em outros lugares; o custo da não existência dos bens informacionais na biblioteca e em lugares alternativos, sinalizando a perda do bem, além do custo da não existência da biblioteca para os funcionários, que sinalizaria perda de qualidade de vida; o gasto da biblioteca na comunidade local; e o gasto dos usuários no comércio local. O retorno de investimento total resulta na média do retorno de investimento 
de cada um dos itens avaliados. O resultado do retorno de investimento, na abordagem mais conservadora, foi de \$5,31 dólares para cada dólar investido.

Cervone (2010, p. 76) explica os fundamentos da análise de custo-benefício a fim de servir de base para justificar gastos com bibliotecas digitais e chega à conclusão de que é possível fazer cálculos com base em itens de mercado e bens tangíveis em geral, mas o resultado sempre fica comprometido, por conta do alto grau de intangibilidade que existem nos negócios de informação.

Lee, Chung e Jung (2010, p. 240) avaliam a disposição a pagar dos coreanos pelos serviços das bibliotecas públicas. Apesar de declarar que foi avaliada a disposição a pagar, a pesquisa mostra que o estudo foi baseado na disposição a aceitar. A proposta dos autores foi provar que o método de valoração contingente pode ser enviesado pela existência de um problema denominado 'warm glow'. Segundo a hipótese dos autores, as pessoas possuem um sentimento de prazer em fazer doações às instituições que oferecem bens públicos, que impediriam a obtenção do valor que eles realmente pagariam pelos bens. A diferença do warm glow para o altruísmo seria que o primeiro se trata de uma ação egoísta, mesmo que beneficie outras pessoas. O método utilizado para a redução desse fenômeno foi a adoção de questionários mais fluidos com perguntas complementares. Os resultados confirmam a hipótese apresentada pelos autores.

Mathews (2011, p. 10) diz que, apesar de apresentar retornos de investimento positivos a seus mantenedores, algumas bibliotecas públicas americanas continuaram sofrendo cortes financeiros. As bibliotecas estudadas foram a Carnegie Library of Pittsburgh, a Utah State Library e a rede Douglas County Libraries in Colorado. Em todos os casos, as medidas tiveram impacto positivo no sentido de trazer visibilidade para a biblioteca e justificar o investimento, mas isso não foi suficiente para evitar que a biblioteca sofresse os cortes orçamentários.

Ainda segundo Mathews (2011, p. 11), todas as bibliotecas podem elaborar relatórios de Retorno de Investimento (RI), com base nas finanças e nos custos que a fazem os usuários evitar. Porém, para estudos mais aprofundados que utilizam metodologias que os bibliotecários não possuem expertise, muitas bibliotecas precisam recorrer a consultores externos, cujos valores, segundo o autor, podem chegar a dez mil dólares, no caso de estudos de impacto, e a cinquenta mil dólares, no caso de estudos por valoração contingente.

Guerrero, Rodriguez e Garcia (2012) propõem um método para valoração de coleções de publicações seriadas para a Biblioteca Médica Nacional de Cuba. Os autores relatam a importância de valorar coleções de bibliotecas como ativos tangíveis, para facilitar 
as auditorias e contratações de serviços de seguros, por exemplo. Diante da necessidade de preservação das informações, no formato em que foram feitos, os livros e revistas passam a ser considerados bens tangíveis depreciáveis, tendo em vista que o conhecimento registrado perde valor com o tempo e a parte física está sujeita À deterioração. O valor da coleção de revista foi estimado tendo como base o valor da assinatura anual da coleção, o valor individual de cada fascículo, o valor econômico básico anual e o valor depreciado anual. O valor da assinatura da coleção e o valor de cada fascículo são conseguidos com as informações presentes nos próprios documentos. O valor econômico básico anual é obtido pela multiplicação do preço unitário por fascículo com o numero total de fascículos adquiridos pela instituição. O Valor depreciado é obtido por meio da aplicação de um método de depreciação de periódicos, baseado na lei de Brookes.

Ko et al. (2012, p. 117) apresentam a valoração das bibliotecas públicas coreanas, com método de contingência e retorno de investimento estimado em $\$ 3,66$ wons coreanos., para cada \$1 won coreano investido.

Lee e Chung (2012, p. 72) valoram as bibliotecas públicas por meio do método de valoração contingente, a fim de medir a influência dos motivos altruísticos no valor total. $\mathrm{O}$ altruísmo é dividido em quatro tipos: local, global, paternalista e não-paternalista. Os resultados comprovam que o altruísmo, de fato, influencia na disposição a pagar dos indivíduos, mas os autores indicam que os altruísmos local e não-paternalista devem ser excluídos do valor total, pro não tratarem de altruísmo legítimo.

Outra meta-análise, apresentada pelo Consejo de Cooperación Bibliotecária (2013, p. 2), define três classificações para os métodos de valoração. A primeira classificação é denominada Valor Econômico Estimado (VEE) e compreende os métodos de Valoração Contingente (VC) e a Analogia com o Mercado (AM). O resultado desse tipo de valoração costuma ser o cálculo do valor estimado per capita e o valor total de uma rede de bibliotecas. A segunda classificação é o Benefício Econômico Estimado (BEE) e compreende os métodos de Retorno de Investimento (RI) e o Retorno Social de Investimento (RSI). Esses métodos apresentam os resultados do retorno econômico para o usuário e os benefícios para o meio ambiente e para a sociedade, por meio de uma razão que mostra o retorno financeiro para cada unidade monetária investida na biblioteca. A terceira classificação é chamada de Atividade Econômica Estimada (AEE), que calcula os gastos que influenciam no desenvolvimento da economia local e geral. Os resultados desse método costumam ser o Relatório de Valor Acrescentado (RVA) e do Impacto Econômico Direto Total (IEDT). 
McIntosh (2013, p. 124) compara o uso dos métodos dos custos evitados e valoração contingente na literatura e chega à conclusão de que a valoração contingente tende a ser mais efetiva. Segundo o autor, o resultado do método dos custos evitados, quando utilizado para estimar os benefícios das bibliotecas em análises de retorno de investimento, tende a superestimar os benefícios dos usuários, usar porcentagens de desconto arbitrárias e, por isso, são inconsistentes em termos de teoria. Por outro lado, a valoração contingente possui uma base teórica mais consistente e leva a uma estimativa de benefícios mais real. $\mathrm{O}$ autor também enfatiza que o estudo de valoração contingente é trabalhoso e exige muita precaução, mas ainda assim é preferível diante dos resultados de custos evitados.

Diferentemente do estudo aplicado por Aabo (2005) ao valorar as bibliotecas norueguesas, Hájek e Stjskal (2014, p. 43) fazem uma valoração contingente aplicando um questionário medindo a disposição a pagar, contando com dinheiro do próprio bolso, e a disposição a aceitar, a partir da alocação de dinheiro dos impostos já pagos. O propósito dessa metodologia seria compensar a questão vista no estudo de Aabo, que diz que as pessoas tendem a disponibilizar menos dinheiro para algum serviço que julga merecer. Além disso, foram perguntados os gastos dos usuários para chegar à biblioteca, o tempo de acesso e os gastos alternativos, caso a biblioteca não existisse. Os resultados foram positivos e, conforme o esperado, a disposição a aceitar foi quase seis vezes superior à disposição a pagar.

Hernon, Dungan e Mathews (2014, p. 138) também defendem o uso da Análise de Custo-Benefício (ACB), sendo apresentada como sinônimo de Retorno de Investimento (RI), sendo que o ultimo nome é apresentado como o usado pelos estudos feitos pelas bibliotecas. Porém, diferentemente do que dizem Elliot et al. (2007, p. 11) ao defenderem que se deve apenas fazer análises mais conservadores, Hernon, Dungan e Mathews (2014, p. 153) acreditam que análises mais aprofundadas precisam ser feitas, pois o valor de uso indireto e o valor de não-uso também são muito importantes para serem apresentados aos tomadores de decisão. Os autores apresentam o conceito de Valor Econômico Total, mas atentam para o fato de que os resultados não são totalmente precisos devido às dificuldades metodológicas de avaliar esses valores de uso indireto e não-uso, mesmo assim, acreditam ser uma medida válida.

Yañez (2014, p. 9) propõe e aplica a valoração das bibliotecas públicas espanholas por meio de análise do impacto econômico, valoração contingente e Retorno de investimento.

Bano e Haridasan (2015, p. 251) conduziram a valoração da coleção de jornais impressos e digitais da Maulana Azad Library que fica na Aligarh Muslim University- Índia. O método utilizado foi a valoração contingente, onde foi perguntado apenas a disposição dos 
usuários a pagar pelo uso dessa coleção. O resultado da valoração foram utilizados para fazer analise de custo-benefício (1:3,9 rúpias) e retorno de investimento (287\%).

Shepherd, Vardy e Wilson (2015, p. 448) analisam a aplicação de uma metodologia que mede o tempo médio de consumo dos bens informacionais, seja em uso local ou em empréstimos domiciliares. Esse tipo de medida é mais comum em estudos de uso do lazer promovido pela televisão. Após a contagem média do tempo gasto pelos usuários, os autores sugerem a aplicação de valoração contingente, para medir a disposição dos usuários a pagar por esse tempo de consumo. Na amostra de produtos circuláveis utilizados pelos autores, não foram incluídos arquivos digitais disponibilizados online. Durante a aplicação desse método em uma biblioteca pública canadense foi estimado que o tempo médio de consumo de todos os itens da biblioteca no mês de agosto de 2013 foi de 182 mil horas. O resultado da valoração contingente diz que o valor médio que os usuários estão dispostos a pagar por hora de uso de material impresso é de $\$ 6,55$ dólares canadenses e para uso de material digital foi de $\$ 3,15$ dólares canadenses.

Stejskal e Hajek (2015, p. 351) utiliza o método de valoração contingente, associado ao retorno de investimento, para medir a efetividade dos serviços digitais da Biblioteca municipal de Praga, na República Tcheca. Os usuários foram questionados quanto suas disposições a pagar pelos serviços digitais da biblioteca e esses resultados foram comparados com os custos totais da biblioteca. Esses resultados foram comparados com um estudo prévio feito com os serviços existentes na biblioteca física. Os resultados mostram que o custo-benefício e o retorno de investimento para serviços feitos pessoalmente na biblioteca não mostraram bons resultados. O custo-benefício foi medido da seguinte forma:CB= Custo/Benefício $=1: 0,89$. O retorno de investimento foi medido da seguinte forma: $\mathrm{RI}=$ (Benefícios-Custos)/Custos $=-0,11$. Por outro lado, os resultados se mostraram muito positivos quando se trata de serviços digitais, resultando $\mathrm{CB}=1: 4,02$ e $\mathrm{RI}=3,02$.

\subsection{Análise dos documentos}

A partir da análise dos textos utilizados nesse estudo, a respeito do uso de métodos de valoração econômica de bibliotecas, pode-se fazer as seguintes observações:

Importância do assunto em função do tempo: Os estudos sobre valoração de bens públicos, conforme foi relatado no capítulo 2 , começaram a ser intensificados na segunda metade do 
século XXI. Os primeiros estudos sobre valoração econômica de bibliotecas começaram ser publicados apenas em meados da década de 1990. A valoração econômica das bibliotecas públicas dos Estados Unidos e da Noruega se tornou um marco, pois passou a ser parâmetro para a elaboração de pesquisas em outros países, que tinham como objetivo utilizar, estudar ou refutar os métodos utilizados por eles. A valoração de bibliotecas se tornou um assunto relevante, pois é crescente a demanda de que a biblioteca dê retornos a seus mantenedores, como prova de que seus serviços são de fato úteis e lucrativos. Isso se exemplifica no crescimento da quantidade de publicações relacionadas a esse tema nos últimos anos. Pode-se observar o aumento na quantidade de estudos publicados na primeira década dos anos 2000, conforme pode ser observado no gráfico 2 .

Figura 3: Representação gráfica da evolução da quantidade de estudos

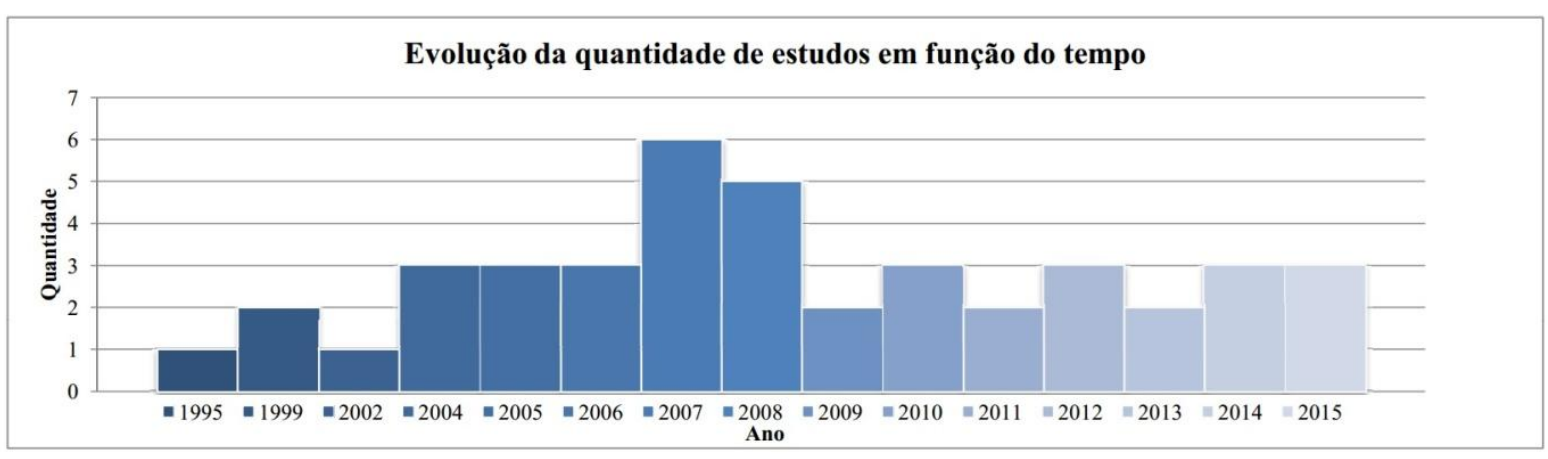

Fonte: Elaborado pelo autor

Falta de consenso quanto aos conceitos: Foram encontrados dois conceitos diferentes para Valor Econômico Total (VET). O conceito de VET, segundo Hernon, Dungan e Mathews (2014), Lee e Chung (2012); do Consejo de Cooperación Bibliotecária (2013) e do Arts Council England (2008); condizem com o padrão que define VET como a soma do valor de uso e do valor de não-uso. Porém, o NorthStar Economics (2007) chama de Valor Econômico Total a -soma do valor de mercado de todos os produtos e serviços.

A falta de padronização dos conceitos indica uma necessidade de pensar uma taxonomia de métodos de valoração, a fim de definir uma hierarquia de métodos e ferramentas para se alcançar o valor econômico das bibliotecas.

Difusão das pesquisas pelo mundo: Observa-se que as primeiras publicações eram concentradas nos Estados Unidos da América e na Noruega. Porém, como o passar do tempo, outros países desenvolveram pesquisa relacionadas aio assunto. A Figura 1 mostra os países nos quais já foram identificados estudos relacionados à valoração de bibliotecas. Destaca-se 
não ter sido encontrado estudo de valoração de bibliotecas no continente sul americano. Destaca-se também o fato de que à exceção da Índia e de Cuba (que utilizou um método alternativo), todos os países onde foram desenvolvidas pesquisas relativas à valoração de bibliotecas são desenvolvidos. Isso talvez se explique devido ao fato citado por Mathews (2011) de que os estudos de valoração de bibliotecas possuem alto custo.

Figura 4: Panorama da valoração econômica de bibliotecas

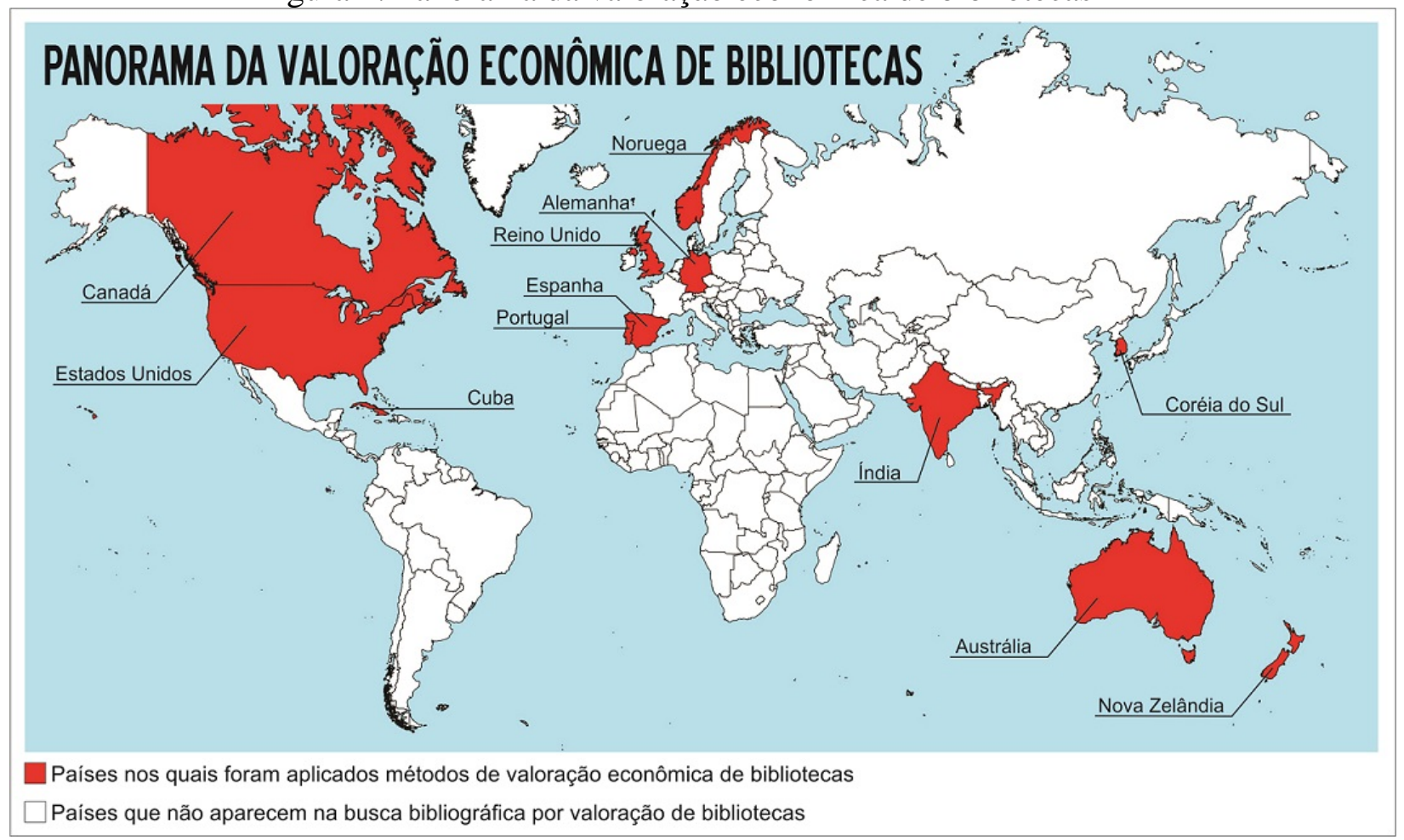

Fonte: Elaborado pelo autor

Falta de consenso na forma de aplicar métodos: Apesar do método de valoração contingente ser o mais usado entre os estudos, os autores divergem quanto à aplicação completa desse método, incluindo o valor de não-uso.

Muitos autores defendem a medição apenas do valor de uso, na tentativa de fazer um estudo mais conservador e com menos chance de refutação dos resultados. Esses autores defendem que a valoração deve levar em conta apenas os valores reais, de custo, de mercado e da disposição a pagar. Para eles, é possível inferir a partir do conhecimento da existência de valores não medidos, que a biblioteca possui mais valor além do que já foi apresentado pelos métodos conservadores. Essa justificativa se torna válida, tendo em vista que não existe método com total segurança dos resultados. Outros autores defendem a aplicação da valoração do não-uso, pois os valores seriam mais realistas. 
O Quadro 2 lista os autores de acordo com seus pontos de vista, quanto a defesa ou aplicação do valor de não-uso.

Quadro 2: Opinião dos autores quanto ao valor de não-uso

\begin{tabular}{|c|c|}
\hline \multicolumn{2}{|c|}{ Opinião dos autores quanto ao valor de não-uso } \\
\hline $\begin{array}{c}\text { Defendem ou utilizam o } \\
\text { valor de não-uso }\end{array}$ & $\begin{array}{c}\text { Não usam ou não recomendam o } \\
\text { valor de não-uso }\end{array}$ \\
\hline Holt et al. (1999 apud AABO; STRAND, 2004) & Elliot et al. (2007, p. 11) \\
\hline Aabo e Adunson (2002) & Bano e Haridasan (2015, p. 251) \\
\hline Aabo e Strand (2004) & Shepherd, Vardy e Wilson (2015, p. 448) \\
\hline Stephen et al. (2009) & Stejskal e Hajek (2015, p. 351) \\
\hline Hernon, Dungan e Mathews (2014) & Griffiths, king e Lynch (2004) \\
\hline Lee, Chung e Jung (2010) & SLISUSC (2005) \\
\hline Lee e Chung (2012) & Griffiths et al. (2006) \\
\hline McIntosh (2013, p. 124) & LDF (2006) \\
\hline & LDF (2007) \\
\hline & Steffen et al. (2009) \\
\hline & BBER (2011) \\
\hline
\end{tabular}

Fonte: Elaborado pelo Autor

Tipo de biblioteca que foi objeto de valoração econômica com mais frequência: As bibliotecas públicas são as que mais possuem estudos de valoração econômica. Esse fato é confirmado pela afirmação de Aabo (2009, p. 313), ao dizer que é necessário desenvolver mais estudos para bibliotecas escolares, especializadas, nacionais e universitárias. A distribuição dos estudos por tipo de biblioteca pode ser observada na Figura 5.

Figura 5: Representação gráfica da distribuição dos tipos de biblioteca

\section{Distribuição dos tipos de biblioteca}

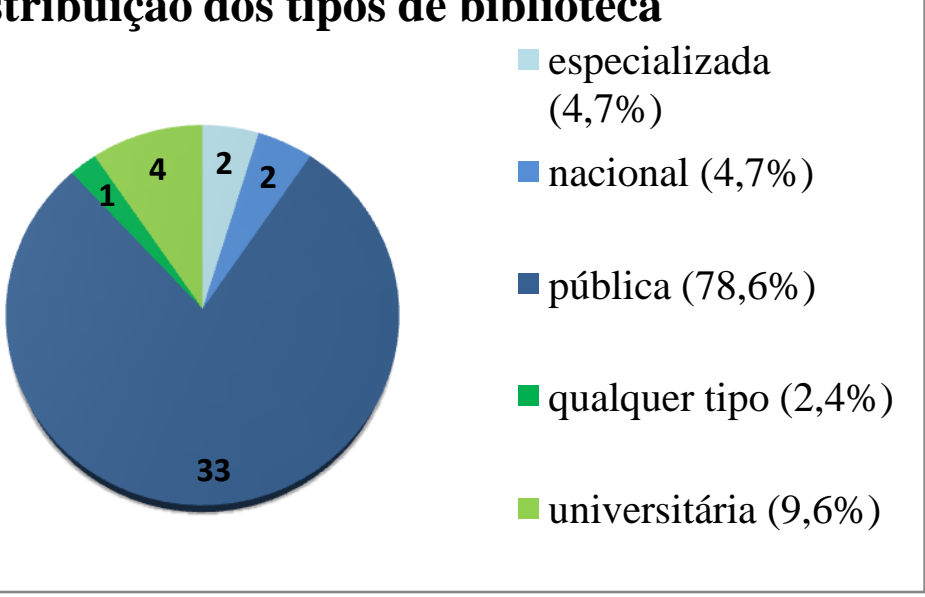

Fonte:Elaborado pelo autor 
Bens e serviços que foram objetos de estudos de valoração com mais frequência: A maior parte dos estudos propôs métodos para a valoração econômica da biblioteca como um todo. Apesar disso, todos os autores concordam que existem limitações, que não permitem que o valor das bibliotecas seja definido com exatidão. White (2007, p. 07), por exemplo, sugere que os serviços e produtos sejam valorados separadamente. A Figura 6 apresenta os objetos mais valorados economicamente nas bibliotecas.

Figura 6: Representação gráfica dos objetos valorados

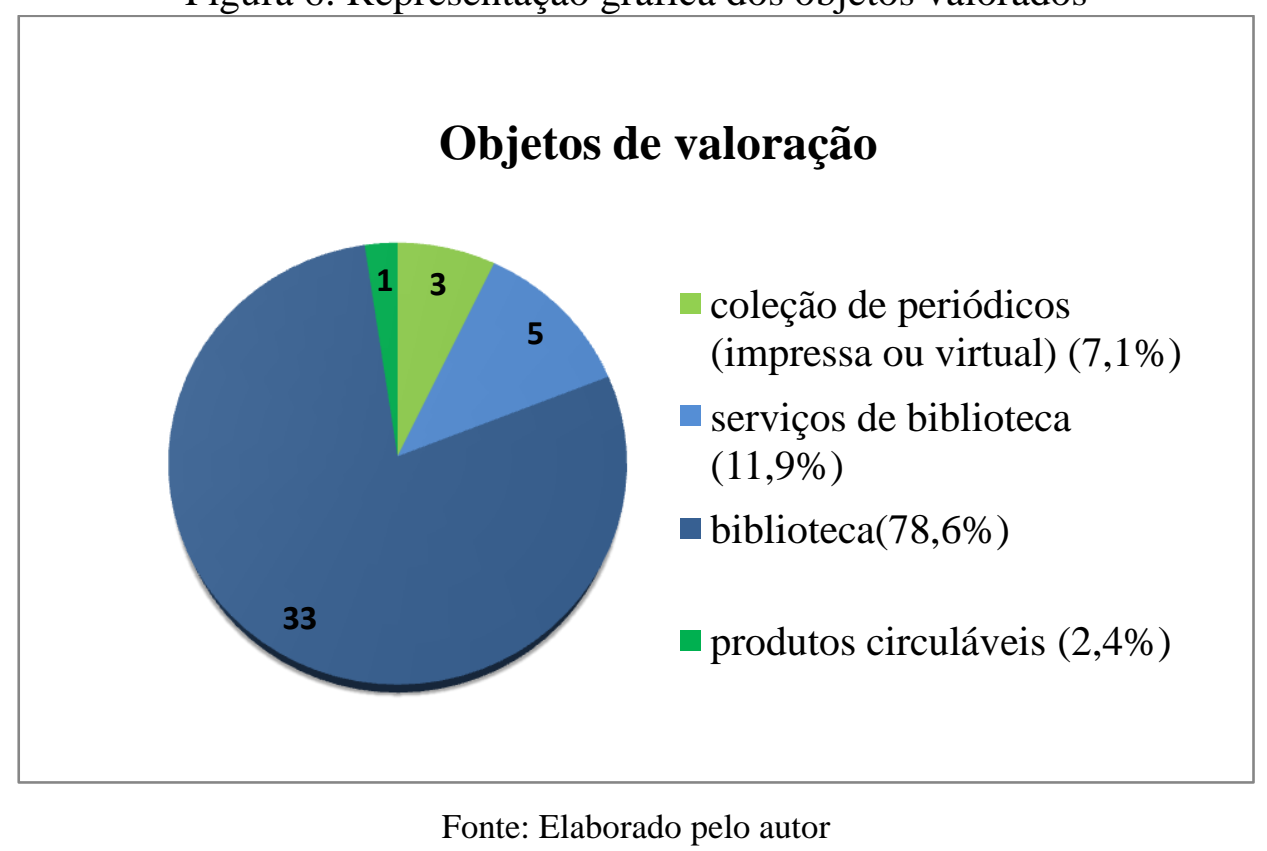

Métodos alternativos de valoração: Diante da falta de métodos mais apropriados que representem o valor econômico das bibliotecas com precisão, muitos autores trabalham na tentativa de solucionar os problemas dos métodos existentes, a partir de pequenas alterações metodológicas ou a partir da criação de outros métodos.

A abordagem comum da medida da disposição a pagar e da disposição a aceitar compensação é feita com o entendimento que o usuário vai dispor do próprio dinheiro para valorar a biblioteca. Porém, na realidade das bibliotecas públicas, Aabo (2005b) propõe que a disposição a aceitar seja medida com o quanto o usuário gostaria que fosse enviado para a biblioteca, dentro do montante de impostos que ele paga. Kamer (2006) e Hájek e Stjskal (2014) por outro lado, sugerem que a disposição a pagar seja feita com base nos impostos já pagos pelo usuário. Os resultados, de fato, são influenciados por essas medidas.

Chung (2008) identifica na literatura possíveis vieses relacionados à elaboração de questionários, no decorrer da aplicação do método de valoração contingente. A partir da 
identificação desses vieses, o autor propõe alterações na elaboração de questionários, a fim de diminuir problemas e tornar os resultados da valoração contingente mais confiáveis e menos passiveis de serem questionados.

Griffiths et al.(2006) sugerem a avaliação do impacto econômico por meio de um método chamado REMI e Elliot et al. (2007) propõem a medição dos benefícios das bibliotecas por meio da matriz de usuário serviço.

Guerrero, Rodriguez e Garcia (2012) sugerem a valoração de acervos por meio de métodos de depreciação. Talvez isso aconteça devido ao fato de que em Cuba, com o acesso restrito à internet, as informações ainda sejam observadas sob o ponto de vista do suporte onde se encontram.

\subsubsection{Considerações sobre os métodos}

Observou-se a escassez de estudos relacionados à valoração de duas importantes características das bibliotecas.

A primeira característica é a dualidade entre a informação e o suporte. Não é claro, na literatura, o que se avalia em termos de bens informacionais. Um livro não é apenas o material usado em suas propriedades físicas. O mesmo pode ser afirmado para um acervo. Existe uma carência de métodos que agreguem a tangibilidade e a intangibilidade da informação. O valor de mercado de um bem informacional está relacionado com o caminho que se toma para chegar até ele e o preço que as pessoas estão dispostas a pagar. Porém, não existe método de valoração do objetivo e do impacto que essa informação possui. O valor da informação está mais relacionado ao uso que se faz dela, enquanto o suporte está relacionado ao caminho que se faz até chegar a ele. Em uma única viagem para a biblioteca, é possível ter acesso a informações culturais e recreativas ao mesmo tempo em que se recebem informações estratégicas que vão servir de suporte a uma tomada de decisões. Observa-se assim que o valor de cada tipo informação é diferente e que uma mesma informação pode ter valores diferentes de acordo com o tio de usuário, mas não há métodos que contemplem essas diferenças. Da mesma forma, não há indicações claras de que o valor do suporte e o valor da informação são independentes. E somente isso justificaria a conservação de itens físicos, sendo que a preservação de itens digitais possui menos custo, na Economia da Informação.

A segunda característica diz respeito às implicações éticas que o livre acesso à informação traz. As tecnologias facilitam a ação dos free-riders que procuram acesso gratuito a informações privadas. $\mathrm{O}$ acesso a informações bibliográficas ficou facilitado com o advento 
da tecnologia. De uma forma geral, as bibliotecas já possuem redes de informação que garantem acesso às informações bibliográficas em curto e médio prazo. Porém, a internet traz a oportunidade de piratear a informação e conseguir acesso imediato. Não existe na literatura algum método que valore a ação ou não-ação de free-riders no mercado da informação.

Observou-se também certa distância entre a literatura da valoração da informação e da valoração do conhecimento. Autores como Polanyi, presentes da valoração do conhecimento, podem trazer à luz conceitos e pontos de vistas distintos, inclusive para as duas questões apontadas nessas considerações. No primeiro caso, Polanyi (apud Cardoso; Cardoso, 2007) trata da impossibilidade de medir o valor do conhecimento, a partir da teoria dos mercados fictícios. No segundo caso, ainda de acordo com o autor, é possível questionar a pirataria, os direitos autorais e patentes, a partir da definição do conhecimento como algo que não é privado, mas social.

\subsection{Proposição de métodos de valoração econômica para a Biblioteca do Ipea}

\subsubsection{O Instituto de Pesquisa Econômica Aplicada (Ipea)}

O Instituto de Pesquisa Econômica Aplicada (Ipea) é uma fundação pública federal vinculada à Secretaria de Assuntos Estratégicos da Presidência da República. Suas atividades de pesquisa fornecem suporte técnico e institucional às ações governamentais para a formulação e reformulação de políticas públicas e programas de desenvolvimento brasileiros. Isso mostra o caminho do Ipea em alcançar sua atual missão institucional de “Aprimorar as políticas públicas essenciais ao desenvolvimento brasileiro, por meio da produção e disseminação de conhecimentos e da assessoria ao Estado nas suas decisões estratégicas". (IPEA, 2016)

Para o cumprimento de sua missão institucional, o Ipea dispõe de um corpo técnico altamente qualificado, além de uma infraestrutura física e tecnológica que oferece suporte ao desenvolvimento das atividades internas do Instituto. O alcance da missão institucional de produção e disseminação do conhecimento depende do bom desempenho de todas as áreas do Instituto por onde circula a informação que será entregue no final dos estudos. Além disso, muitas informações que são produzidas diariamente no âmbito de gestão organizacional são fundamentais para o funcionamento do Instituto. Nota-se, portanto, que sendo a informação o principal produto do Ipea, deve-se existir uma atenção especial do 
Instituto para que, a partir do uso e da qualidade dessa informação produzida, possa ser avaliada a eficiência de suas atividades fins.

Para que a informação produzida pelo Ipea possa chegar ao usuário final, por

meio das publicações, eventos, programas de TV e demais formas de divulgação e disseminação que o Ipea dispõe, existe um complexo fluxo informacional, que abrange etapas de produção, tratamento e divulgação de informações para o qual é essencial o funcionamento adequado do ciclo informacional na instituição.

\subsubsection{A Biblioteca do Ipea}

A Biblioteca do Ipea assume um papel essencial dentro da instituição, que é o de fornecer produtos e serviços que forneçam suporte bibliográfico e informacional para o desenvolvimento do trabalho de todos os servidores, tanto nos trabalhos relacionados à administração e suporte, quanto nas atividades de pesquisa.

A fundação da Biblioteca se confunde com a história do próprio Instituto, tendo sido fundada em 1965. Desde 1970, com a mudança da sede do Ipea para Brasília, a Biblioteca do Ipea atua tanto em Brasília, quanto no Rio de Janeiro.

A missão da Biblioteca é planejar, coordenar, preservar e controlar a memória da produção bibliográfica do Ipea e o acervo bibliográfico, bem como executar atividades de análise, pesquisa, busca e divulgação de informação bibliográfica. (IPEA, 2012)

Para cumprir essa missão, a Biblioteca dispõe de bibliotecários e auxiliares de biblioteca, divididos em 5 setores: Gerenciamento, Processamento Técnico, Referência/Circulação, Desenvolvimento de Coleções e Legislação.

Os principais produtos disponibilizados pela Biblioteca são:

Acervo físico: é especializado em especializado em Economia, políticas governamentais e planejamento econômico e social. Atualmente conta com aproximadamente 60 mil registros, formados por livros, periódicos, teses e dissertações, mapas, jornais, CD-ROMs e DVDs.

Acervo digital: Formada por bases de livros eletrônicos e bases de periódicos assinadas, que fornece suporte em diversas áreas do conhecimento, sobretudo Ciências Sociais.

Memória Técnica: Trata-se de uma catálogo digital e o acervo físico referente a todas as publicações feitas ou editadas pelo Ipea. 


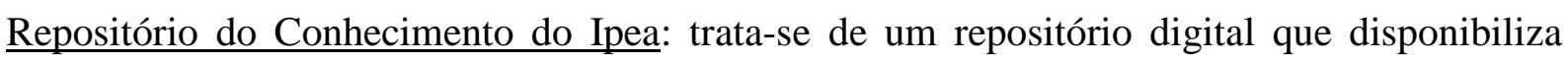
todas as publicações do Ipea disponibilizadas em formato eletrônico. Além disso, o repositório se dispõe a armazenar também informações que não foram publicadas pelo Instituto, a fim de captar e registrar o conhecimento de seus servidores.

Base de legislação: Base de dados que compila todas as informações de caráter jurídico referentes ao Ipea, desde sua fundação.

Os principais serviços da biblioteca são:

Empréstimo: trata-se da disponibilização física de itens do acervo aos usuários. Ressalta-se que estão disponíveis para empréstimo todo o acervo das bibliotecas de instituições parceiras, por meio das redes de biblioteca. Assim, mesmo que o Instituto não disponha de determinado item informacional, este pode ser obtido em qualquer biblioteca da rede.

Referência e pesquisa: Trata-se do atendimento personalizado, feito pessoalmente ou virtualmente, a fim de atender às demandas informacionais dos usuários.

Catalogação na fonte: trata-se da criação de fichas catalográficas para todas as publicações do Ipea. Inclui-se nesse serviço todos os tipos de atividades bibliográficas que possam ser eventualmente solicitadas à biblioteca, como criação de referências ou padronização de acordo com normas técnicas.

Depósito legal: trata-se da garantia de que todo o acervo bibliográfico produzido e editado pelo Ipea será guardado e preservado, em formato físico e digital, a fim de preservar a história da Instituição e do país.

\subsubsection{Proposição de métodos de valoração econômica}

Por se tratar de uma biblioteca pertencente a uma instituição pública, os usuários não investem dinheiro diretamente e acreditam ter direito ao uso do bem e, portanto, poucos serviços podem ser valorados com o método da valoração contingente. Recomenda-se esse método para fazer valoração econômica de dois bens informacionais: O primeiro é o acervo físico de memória técnica. Por se tratar de um bem de valor cultural para o país, é possível 
utilizar a VC, como recomendado por MLA (2008). Deve-se levar em consideração que, nesse caso, a valoração somente funciona para o suporte físico, tendo em vista que os documentos podem ser digitalizados e preservados em outros suportes. O segundo é a biblioteca como um todo, porém a partir de uma adaptação da VC, conforme sugerido por Aabo (2009), Kamer (2006) e Hájek e Stjskal (2014). Sugere-se perguntar aos servidores (usuários e não-usuários) a DAP e a DAA, tendo como base o orçamento total do Ipea, que é proveniente de dinheiro público.

Para valorar os serviços de referência presencial e digital, os acervos físico e digital, sugere-se usar o valor do tempo, valor de mercado e o custo de viagem para chegar em outras fontes. No caso do valor do tempo, deve-se calcular a média de tempo que o usuário demoraria para obter esses bens e fazer uma razão com a hora-salário dos servidores. Deve-se valorar também o tempo investido pelos servidores para obtenção das informações, em comparação com o tempo do usuário . No caso do valor de mercado, deve-se calcular qual o custo que geraria para os usuários, para conseguir acesso aos mesmos serviços em outras fontes, caso existam. Esses custos devem incluir os gastos relativos à viagem ao local.

Para valorar a base de legislação, sugere-se valorar o tempo que o usuário demoraria para conseguir encontrar as informações em outras fontes. Tendo em vista que as informações sobre legislação são gratuitas, não seria possível usar o método de valor do mercado. Apesar da recomendação de Elliot et al. (2007, p. 11) para não usar a valoração do tempo, nesse caso, o tempo do usuário pode ser medido facilmente a partir de seu salário. Deve-se usar valorar também o tempo que o funcionário gasta para a criação, manutenção e atualização da base. Além disso, deve-se valorar o valor de aquisição e armazenamento digital das bases.

Para fazer a análise de custo benefício, deve-se comparar o valor encontrado por esses métodos com o custo total investido para a disponibilização desses bens.

O resumo das sugestões pode ser observado no Quadro 3: 
Quadro 3 - Resumo das sugestões de métodos de valoração para a Biblioteca do Ipea

\begin{tabular}{|c|c|c|c|}
\hline Objeto valorado & Métodos & Referencial teórico & $\begin{array}{l}\text { Principais limitações } \\
\text { dos resultados }\end{array}$ \\
\hline $\begin{array}{l}\text { Acervo físico da } \\
\text { memória técnica }\end{array}$ & $\mathrm{VC}$ & MLA (2008) & $\begin{array}{l}\text { Não valora totalmente o } \\
\text { conteúdo disponibilizado, } \\
\text { mas apenas a preservação } \\
\text { do suporte físico para } \\
\text { fins históricos e culturais. }\end{array}$ \\
\hline $\begin{array}{l}\text { Biblioteca como } \\
\text { um todo }\end{array}$ & $\begin{array}{l}\text { VC adaptado (DAP e } \\
\text { DAA, baseado no } \\
\text { orçamento total do } \\
\text { Ipea) }\end{array}$ & $\begin{array}{c}\text { Aabo (2009), Kamer } \\
\text { (2006) e Hájek e Stjskal } \\
\text { (2014). }\end{array}$ & $\begin{array}{l}\text { Não valora o impacto } \\
\text { estratégico das } \\
\text { informações } \\
\text { disponibilizadas; Método } \\
\text { passível de ser } \\
\text { questionado } \\
\text { conceitualmente, tendo } \\
\text { em vista que foge do } \\
\text { padrão de pedir às } \\
\text { pessoas que valorem a } \\
\text { partir do valor do próprio } \\
\text { bolso. }\end{array}$ \\
\hline $\begin{array}{l}\text { Referência digital e } \\
\text { presencial }\end{array}$ & $\begin{array}{l}\text { Valor do tempo/ } \\
\text { Valor de mercado/ } \\
\text { Custo de viagem/ } \\
\text { Custo de manutenção } \\
\text { e armazenamento de } \\
\text { objetos digitais }\end{array}$ & $\begin{array}{l}\text { Valor do tempo: Keyes } \\
\text { (1995), Elliot et al. (2007), } \\
\text { Shepherd, Vardy e Wilson } \\
\text { (2015). Valor de mercado: } \\
\text { Grffiths, King e Lynch } \\
\text { (2004), SLISUS (2005), } \\
\text { Griffiths et al. (2006), LDF } \\
\text { (2006), IRRC (2007), } \\
\text { Norhstar Economics (2007), } \\
\text { MCKerracher (2008), Seffen } \\
\text { et al. (2009) e BBER (2011). } \\
\text { Custo de viagem: Hájek e } \\
\text { Stjskal (2014). }\end{array}$ & $\begin{array}{l}\text { Não valora o impacto } \\
\text { estratégico das } \\
\text { informações } \\
\text { disponibilizadas; Pode } \\
\text { não representar } \\
\text { adequadamente o valor } \\
\text { do serviço, devido ao } \\
\text { fato de que o mercado } \\
\text { pode não oferecer os } \\
\text { mesmos produtos e } \\
\text { serviços }\end{array}$ \\
\hline $\begin{array}{l}\text { Base digital de } \\
\text { legislação }\end{array}$ & $\begin{array}{c}\text { Valor do tempo/ } \\
\text { Custo de manutenção } \\
\text { e armazenamento de } \\
\text { objetos digitais }\end{array}$ & $\begin{array}{l}\text { Valor do tempo: Keyes } \\
\text { (1995), Elliot et al. } \\
\text { (2007), Shepherd, Vardy } \\
\text { e Wilson (2015). }\end{array}$ & $\begin{array}{l}\text { O custo de manutenção e } \\
\text { armazenamento é baixo e } \\
\text { não é exclusivo apenas } \\
\text { para essa função, } \\
\text { portanto, não representa } \\
\text { totalmente o valor } \\
\text { econômico da base. }\end{array}$ \\
\hline
\end{tabular}

Fonte: Elaborado pelo autor 


\section{CONSIDERAÇÕES FINAIS}

Mesmo diante da popularização da internet e das facilidades de acesso proporcionadas pelas tecnologias de informação, as bibliotecas continuam exercendo funções essenciais para seus respectivos mantenedores e para a sociedade. $\mathrm{O}$ crescimento exponencial da produção e do acesso à informação criou uma necessidade ainda maior de existir métodos de organização e recuperação de informações, os quais as bibliotecas possuem a expertise desenvolvida por muitos séculos. Dessa forma, a internet e as tecnologias da informação não são concorrentes dos serviços bibliotecários. Ao contrário disso, elas potencializam o alcance desses serviços.

A partir disso, as bibliotecas assumem papéis fundamentais de mediadoras e provedoras de acesso à informação, diante de uma sociedade onde o acesso à informação é sinônimo de desenvolvimento. Isso implica no caráter social que as bibliotecas possuem, especialmente, as bibliotecas públicas e comunitárias. Um dos principais objetivos buscados pelas iniciativas de criação de uma sociedade global da informação era o de desenvolver uma infraestrutura tecnológica que beneficiasse a todos os indivíduos. As bibliotecas públicas, por sua natureza, tratam de disponibilizar gratuitamente produtos e serviços informacionais permitindo a redução de desigualdades provenientes das diferenças de acesso à informação por parte da população.

A importância do papel desenvolvido pelas bibliotecas varia de acordo com o tipo. Assim, as bibliotecas nacionais possuem grande valor histórico e cultural. Esses valores são encontrados também em todas as bibliotecas cujo acervo possui relevância histórica, como as bibliotecas de instituições públicas, que guardam registros da memória do país, e as coleções de obras raras. As bibliotecas que atendem a públicos específicos exercem funções essenciais à medida que desempenham funções estratégicas em suas instituições. Esse é o caso das bibliotecas escolares e universitárias, cujos produtos e serviços fazem parte do desenvolvimento das funções básicas dessas instituições, e das bibliotecas institucionais, que possuem a capacidade de colaborar para a redução de assimetrias de informação.

Conforme foi apresentado no capítulo 2 dessa dissertação, as assimetrias de informação representam uma falha que impede o funcionamento adequado do mercado. Os mecanismos apresentados para reduzir a ação indesejada de uma das partes da negociação podem ser complementados com a criação de um serviço de informação. Os mecanismos apresentados na literatura são relevantes e alguns deles preveem a existência de bases de dados e informações, como a filtragem e o monitoramento. Mesmo os mecanismos de 
sinalização, as medidas de compromisso e até mesmo o próprio estabelecimento dos temos do contrato podem ser beneficiados com a existência de uma base de dados e informações sobre os clientes, os produtos, as concorrências e sobre a própria empresa (além de qualquer outra informação que seja relevante para a transação). Essas bases, aliadas a um plano de gestão do conhecimento, para captar a experiência dos funcionários em situações anteriores, e a um serviço de inteligência organizacional configuram um recurso de alta relevância estratégica.

A literatura consultada provou que a necessidade de medir o valor econômico das bibliotecas é crescente em todo o mundo. Porém, não existe um método que atenda completamente a determinação do valor econômico das bibliotecas, tendo em vista que as bibliotecas são organizações complexas que tratam de bens intangíveis baseados em informações e conhecimentos. A dificuldade e até mesmo a impossibilidade de medir adequadamente o valor econômico da informação e do conhecimento é previsto na teoria dos mercados fictícios. Isso explica o fato de que os métodos não contemplem a dualidade entre suporte e informação presente nos documentos. Isso explica também a dificuldade de medir o potencial estratégico de determinada informação, pois isso depende do uso e do impacto das decisões futuras que o usuário fará depois de ter contato com a informação; além de depender das habilidades e dos conhecimentos prévios dos usuários. $\mathrm{O}$ valor econômico da informação, portanto, varia de acordo com o usuário e com o uso e o impacto que ela proporciona; além, obviamente, dos outros fatores já apresentados nessa dissertação, como a confiabilidade e a atualidade da informação.

A diferença de valor da informação de acordo com cada usuário exemplifica o motivo que o valor de mercado é diferente do valor econômico. O valor de mercado contempla apenas o custo e a disposição a pagar das pessoas, muitas vezes baseados apenas nas características tangíveis. Isso é possível devido ao fato de que a informação pertence a um ciclo de produção de conhecimento, tratando-se do próprio conhecimento registrado e explicitado. $\mathrm{O}$ processo de explicitação oferece um suporte físico e transforma o conhecimento, que é totalmente intangível, em um produto tangível passível de ser comercializado: a informação. Enquanto produto tangível, a informação pode ser precificada, porém o valor econômico dela precisa levar em consideração suas características intangíveis. Esse é o motivo pelo qual o custo de produção das informações é alto, pois ele depende do resultado da construção do conhecimento e de sua explicitação em um processo que pode durar muitos anos de formação pessoal e experiência por parte dos autores.

Por ouro lado, mesmo diante das dificuldades de medir os produtos e serviços intangíveis das bibliotecas, foram encontrados métodos para avaliar produtos e serviços de 
informação. Embora os métodos sejam diferentes em questões conceituais, os resultados apontados pela aplicação deles possuem resultados positivos. Todos os estudos encontrados na literatura apontam para um retorno positivo dos investimentos em suas respectivas bibliotecas. Sinalizando, assim, que o valor das bibliotecas é ainda superior ao demonstrados nos resultados dos estudos, uma vez que os estudos costumam generalizar o valor da biblioteca a partir da valoração econômica de produtos e serviços selecionados.

Os métodos de valoração econômica apresentados nessa dissertação avaliam as bibliotecas em seus estados e configurações atuais. Mesmo diante dos resultados positivos, a própria necessidade de provar o valor das bibliotecas já sinaliza a necessidade de mudanças e de adaptação ao mercado informacional, que impacta a vida das pessoas diariamente. Por terem como principal produto e serviço a própria informação e para se tornarem essenciais aos olhos dos usuários, as bibliotecas precisam estar à frente, no que diz respeito ao universo da informação. A evolução das TICs e do próprio mercado de informação oferece aos usuários uma extensa gama de produtos e serviços informacionais, disponibilizados por diversos profissionais que recentemente passaram a atuar nesse contexto. Além disso, os usuários estão cada vez mais independentes e possuem competências informacionais desenvolvidas a partir da relação com a tecnologia. Porém, isso não significa que os usuários não possuem mais necessidades informacionais, que o mercado supre essas necessidades e nem que as bibliotecas não podem oferecer serviços relevantes e diferenciados. Isso significa que as necessidades dos usuários mudam constantemente e que, para suprir essas necessidades, os serviços de informação precisam ser cada vez mais especializados.

A partir de todos os resultados apresentados, conclui-se que este estudo alcançou todos os objetivos gerais e específicos que foram propostos. Para estudos futuros, sugere-se:

- Aplicar os métodos sugeridos para a valoração econômica da Biblioteca do Ipea;

- Ampliar a revisão de literatura, a afim obter um alcance maior de autores e métodos de valoração econômica de bibliotecas, a partir do estudo dos textos citados nos textos utilizados nessa dissertação;

- Fazer revisão da literatura sobre valoração do conhecimento e avaliar a aplicação dela em métodos de valoração econômica de bibliotecas;

- Criar e propor métodos que valorem adequadamente bens informacionais, levando em consideração a dualidade do valor da informação em seus aspectos tangíveis e intangíveis;

- Criar métodos de valorar questões éticas relacionadas à pirataria de informação e direitos autorais. 


\section{REFERÊNCIAS BIBLIOGRÁFICAS}

Arts Council England. Evidence review of the economic contribution of libraries. London: Bop Consulting, 2014.

AABO, Svanhild. Are public libraries worth their price?: A contingent valuation study of Norwegian public libraries. New Library World, v. 106, n. 1218/1219, 2005, p. 487-495.

AABO, Svanhild; STRAND, Jon. Public library valuation, nonuse values, and altruistic motivations. Library \& Information Science Research, v. 26, n. 2004, p. 351-372.

AABO, Svanhild; AUNDUNSON, Ragnar. Rational choice and valuation of public libraries: can economic models for evaluating non-market goods be applied to public libraries? Jounal of Librarianship and Information Science, v.34, n.1, mar. 2002.

ANDRADE, Marcelo Gelamos. Impactos da internet na indústria farmacêutica: novo modelo de negócios na economia da informação. Dissertação (Mestrado). Disponível em: http://bibliotecadigital.fgv.br/dspace/bitstream/handle/10438/5655/1200102691.pdf?sequence $=1$. Acesso em: 18 ago. 2016 .

AKERLOF, George A. The market for "Lemons": quality uncertainty and the market mechanism. The Quarterly Journal of Economics, v. 84, n. 3. (Aug., 1970), p. 488-500. Disponível em:

https://www.iei.liu.se/nek/730g83/artiklar/1.328833/AkerlofMarketforLemons.pdf. Acesso em: 18 ago. 2016.

BANO, Saba Nasreen; HARIDASAN, Sudharma. Cost-benefit Analysis of Journal Collections at Maulana Azad Library, AMU. Journal of Library \& Information Science, v. 5, n. 2, jun. 2015.

BARCELOS, Tiago Soares. Valoração econômica do santuário do Caraça em Minas Gerais/BR. Ouro Preto: UFOP, 2014. Dissertação (Mestrado). Disponível em: http://www.repositorio.ufop.br/bitstream/123456789/4427/6/DISSERTA\%C3\%87\%C3\%83O _Valora\%C3\%A7\%C3\%A3oEcon\%C3\%B4micaSantu\%C3\%A1rio.pdf. Acesso em: 01 set. 2016.

BBER. Minnesota public libraries' return of investment. Minnesota: IMLS, 2007.

BOMFÁ, Cláudia R.Z. ; FREITAS, Maria do Carmo Duarte; SILVA, Lídia; BORNIA, Antonio. Marketing Científico Electrônico: um novo conceito voltado para periódicos electrônicos. Estudos em Comunicação, v. 5. Disponível em: http://www.ec.ubi.pt/ec/05/pdf/10-bomfa-marketing.pdf. Acesso em: 20 set. 2016

CALDIN, Clarice Fortkamp. A leitura como função terapêutica: biblioterapia. Enc. Bibli: R. Eletr. Bibliotecon. Ci. Inf., Florianópolis, Brasil, n.12, p. 32-44, 2001.

CAMPELO, Bernadete. O movimento da competência informacional:uma perspectiva para o letramento informacional. Ci. Inf., Brasília, v. 32, n. 3, p. 28-37, set./dez. 2003. Disponível em : http://www.scielo.br/pdf/ci/v32n3/19021.pdf. Acesso em 19 set 2016 
CARDOSO, Leonor; CARDOSO, Pedro. Para uma revisão da teoria do conhecimento de Michael Polanyi. Revista Portuguesa de Pedagogia, v. 41, n. 1, 2007. p. 41-54.

CARNEIRO, Déborah Quinderé. Características econômicas do valor de uso e de não uso de parques sobre Dunas. Natal: UFRN, 2014. Dissertação (Mestrado). Disponível em: http://repositorio.ufrn.br:8080/jspui/bitstream/123456789/18256/1/DeborahQC_DISSERT.pd f. Acesso em: 01set. 2016.

CERVONE, H. Using cost benefit analysis to justify digital library projects. OCLC Systems \& Services: International digital library perspectives, v. 26, n 2, p. 76 - 79, 2010.

CEOLIN, Alessandra Carla. Assimetria de informação e sinalização na cadeia bovina. Porto Alegre: UFRGS, 2011. Tese (Doutorado). Disponível em:

http://www.ufrgs.br/nespro/arquivos/teses/tese_alessandra.pdf. Acesso em: 18 ago. 2016.

CHUNG, Hye - Kyung. The contingent valuation method in public libraries. Journal of librarianship and Information Science. v. 40, jun. 2008.

COHEN, Max Fortunato. O uso da informação na economia da informação: um estudo na industria do Estado de São Paulo. São Paulo: EAESP/FGV, 2003. Tese (Doutorado). Disponível em: http://bibliotecadigital.fgv.br/dspace/handle/10438/2559. Acesso em: 01 ago. 2016.

CUNHA, Murilo Bastos da; Cavalcanti, Cordélia Robalinho de Oliveira. Dicionário de Biblioteconomia e Arquivologia. Brasília: Briquet de Lemos, 2008.

ELLIOT, Donald S. et al. Measuring your library's value: how to do a cost-benefit analysis for your public library. Chicago: ALA, 2007.

FERREIRA, Márcia Christina de Barros. A falsa ilusão de ter: investigando os tipos de valor para o consumidor de falsificações. Rio de Janeiro: FGV, 2007. Dissertação (Mestrado).

Disponível em:

http://bibliotecadigital.fgv.br/dspace/bitstream/handle/10438/3728/Mbarros.pdf?sequence=1\& isAllowed=y. Acesso em: 01 set. 2016.

FERREIRA, Rubens da Silva. A sociedade da informação no Brasil: um ensaio sobre os desafios do Estado. Ci. Inf., Brasília, v. 32, n. 1, p. 36-41, jan./abr. 2003. Disponível em: http://www.scielo.br/pdf/ci/v32n1/15971.pdf. Acesso em: 01 ago. 2016.

FONSECA, Edson Nery da. Introdução à biblioteconomia. 2. ed. Brasília: Briquet de Lemos, 2007.

FURIO, Paulo Roberto. Valoração ambiental: aplicação de métodos de valoração em empresas dos setores mineração, papel e celulose e siderurgia. Rio de Janeiro: FGV, 2006.

Dissertação (Mestrado). Disponível em:

http://bibliotecadigital.fgv.br/dspace/bitstream/handle/10438/3961/PauloRFurio.pdf?sequence =1. Acesso em: 01set. 2016 . 
GARCEZ, Eliane Fioravante; CARPES, Gyance. Gestão da informação na biblioteca escolar. Revista ACB: Biblioteconomia em Santa Catarina, Florianópolis, v.11, n.1, p. 63-73, jan./jul., 2006.

GERMANO, Michael. The library value déficit. The bottom line: managing libray finanaces, 2011, v. 24, n. 2, p. $100-106$

GRIFITHS, Jose-Marie. Taxpayer retorn-on-investiment (ROI) in Pennsylvania public libraries. Pennsylvania: UNC, 2006.

HÁJEK, Petr; STEJSKAl, Jan. Modelling public library value using the contingent valuation method: The case of the Municipal Library of Prague. Journal of Librarianship and Information Science, v. 47, n.1, p. 43- 55, 2015,

HÁJEK, Petr; STEJSKAl, Jan. Effectiveness of digital library services as a basis for decisionmaking in public organizations. Library \& Information Science Research, v. 37, 2015, p. 346-352.

IBRC. The Economic Impact of Libraries in Indiana. Indiana: Kelley School of Business, 2007. 90 p.

IPEA. PLANO estratégico do Ipea: 2013-2023. Brasília: Ipea, 2014. Disponível em: http://www.ipea.gov.br/portal/images/stories/PDFs/140506_plano_estrategico_2013_2023.pd f. Acesso em: 18/04/2016.

IPEA. Tutorial da Biblioteca do Ipea. Brasília: Ipea, 2012. Versão 3.0

KEYES, Alison M. The value of the special library: review and analysis. Special Libraries. Summer, 1995.

KO, Young Man. An economic valuation study of public libraries in Korea. Library \& Information Science Research, v.34, 2012, p. 117-124.

LEE; CHUNG. Analyzing altruistic motivations in public library valuation using contingent valuation method. Library \& Information Science Research, v. 34, 2012, p. 72-78.

LEE; CHUNG; JUNG. Assessing the warm glow effect in contingent valuations for public libraries. Journal of Librarianship and Information Science, v. 42, n. 4, p. 236-244, 2010

LUTHER, Judy. University investment in the library: What's the return? A case study at the University of Illinois at Urbana-Champaign. San Diego: Elsevier, 2008.

MACEDO, Valeria et al. Uma análise conceitual da tipologia do trabalhador do conhecimento. Int. J. Knowl. Eng. Manage., Florianópolis, v.4, n.9, p. 147-165, jul/out. 2015. Disponível em: http://incubadora.periodicos.ufsc.br/index.php/IJKEM/article/viewFile/3427/4169. Acesso em: 01 ago. 2016. 
MCINTOSH, Christopher R. Library return on investment: Defending the contingent valuation method for public benefits estimation. Library \& Information Science Research, v. 35, 2013, p. 117-126

MARCONDES, Carlos Henrique. Representação e economia da informação. Ci. Inf., Brasília, v. 30, n. 1, p. 61-70, jan./abr. 2001. Disponível em:

http://www.scielo.br/pdf/ci/v30n1/a08v30n1. Acesso em: 01 ago. 2016.

MARSHALL, Joanne Gard. The value of library and information services in patient care: results of a multisite study. J Med Lib Assoc, v. 101, n.1, Jan. 2013. Disponível em: http://www.ncbi.nlm.nih.gov/pmc/articles/PMC3543128/. Acesso em: 19 set. 2016.

MATTHEWS, Joseph R. What's the Return on ROI?: The Benefits and Challenges of Calculating Your Library's Return on Investment. Library Leadership and management. v.25, n.1.

MCCALLUM, Ian; QUINN, Sherry. Valuing libraries, The Australian Library Journal, v. 53, n. 1, p. 55-69, 2004.

MCKERRACHER, Sue. Assessing the economic value of public libraries for lobbying purposes. 2008

MLA. Economic impact methodologies for the museums, libraries and archives sector: what works and what doesn't. 2008.

MOTTA, Ronaldo Seroa da. Manual para valoração econômica de recursos ambientais. Rio de Janeiro: IPEA;MMA;PNUD;CNPq, 1997. Disponível em:

http://www.terrabrasilis.org.br/ecotecadigital/pdf/manual-para-valoracao-economica-derecursos-ambientais.pdf. Acesso em: 01set. 2016.

MUÑOZ, Juan Pablo Muñoz. Valoração Econômica do Parque Nacional de Brasília. Brasília: UnB, 2015. Dissertação (Mestrado). Disponível em: http://repositorio.unb.br/bitstream/10482/18963/1/2015_JuanPabloMu\%C3\%B1ozMu\%C3\% B1oz.pdf. Acesso em: 01set. 2016.

NORTHSTAR ECONOMICS. The Economic Contribution of Public Library to the Economy of Wisconsin. Wisconsin: NorthStar Economics, 2008.

OLIVEIRA JUNIOR, Arnaldo Freitas de. Valoração econômica da função ambiental de suporte relacionada às atividades de turismo, Brotas, SP. São Carlos: UFSC, 2003. Dissertação (Mestrado). Disponível em:

https://repositorio.ufscar.br/bitstream/handle/ufscar/1761/TeseAFOJ.pdf? sequence=1\&isAllo wed=y. Acesso em: 01set. 2016.

PERRENOUD, Marcelo Alves. Valoração ambiental do Parque Estadual da Serra dos Mar - Núcleo Santa Virgínia. Taubaté: Universidade de Taubaté, 2010. Dissertação (Mestrado). Disponível em: http://www.feg.unesp.br/ delamaro/parque/Dissertacao\%20Marcelo\%20Perrenoud.pdf. Acesso em: 01set. 2016. 
RENCK, Henrique Brusius. Uma avaliação de contratos de crédito sob a ótica da economia da informação. Porto Alegre: UFRGS, 2009. Dissertação (Mestrado). Disponível em: http://www.lume.ufrgs.br/bitstream/handle/10183/18877/000729318.pdf?sequence=1. Acesso em: 18 ago. 2016.

SANTOS, Marcia Mazo; MELLO, Marília de Souza de. Repensando as bibliotecas institucionais:uma experiência nas bibliotecas dos tribunais regionais federais. Cadernos de Informação Jurídica, Brasília, v. 2, n.1, p. 100-122, jan./jun. 2015 !

SANTOS, Plácida Leopoldina Ventura Amorim da Costa; CARVALHO, Angela Maria Grossi de. Sociedade da informação: avanços e retrocessos no acesso e no uso da informação. Inf. \& Soc.:Est., João Pessoa, v.19, n.1, p. 45-55, jan./abr. 2009. Disponível em: http://www.ies.ufpb.br/ojs/index.php/ies/article/viewFile/1782/2687. Acesso em: 01 ago. 2016.

SHEPHERD; VARDY; WILSON. Quantifying patron time-use of a public library. Library Management,v. 36, n.6/7, 2015, p. 448-461.

SILVA, Fabiano Couto Corrêa da. Bibliotecários especialistas: guia de especialidades e recursos informacionais. Brasília: Thesaurus, 2005. 264 p.

SILVA, Rogério Piva da. O valor econômico do patrimônio cultural: o caso da fábrica Rheingantz do Rio Grande - RS. Pelotas: UFP, 2012. Dissertação (Mestrado). Disponível em: http://repositorio.ufpel.edu.br/bitstream/123456789/1039/1/Rogerio_Piva_Silva_Dissertacao. pdf. Acesso em: 01set. 2016.

STEFFEN, Nicolle. Public libraries:a wise investment: a return on linvestment study of Colorado libraries. Colorado: LRS, 2009.

TAGNIN, Fabio. Economia da informação, custos de transação e produtividade: um ensaio sobre os retornos das tecnologias de informação. São Paulo: FGV. Escola de Administração de Empresas de São Paulo, 2004. Dissertação (Mestrado). Disponível em: http://bibliotecadigital.fgv.br/dspace/bitstream/handle/10438/9894/1200500173.pdf?sequence =1. Acesso em: 18 ago. 2016 .

TAKAHASHI,Tadao. Sociedade da informação no Brasil: livro verde. Brasília: Ministério da Ciência e Tecnologia, 2000. Disponível em:

http://www.governoeletronico.gov.br/documentos-e-arquivos/livroverde.pdf. Acesso em: 01 ago. 2016.

TENOPIR, Carol. Measuring the value of the academic library: return on investment and other value measures. The Serials Librarian, n.58, p. 39-48, 2010.

TIGRE, Paulo Bastos. Economia da informação e do conhecimento. Boletim de conjuntura, economia e tecnologia, v 1, n. 2, jul./ago. 2005. Disponível em:

http://revistas.ufpr.br/ret/article/view/29188/18995. Acesso em: 01 ago. 2016.

VALLE, Beto do. Os novos princípios da geração de valor na Economia do

Conhecimento. Disponível em: https://www.linkedin.com/pulse/os-novos- 
princ\%C3\%ADpios-da-gera\%C3\%A7\%C3\%A3o-de-valor-na-economia-do-beto-do-valle. Acesso em: 01 ago. 2016.

VERZOLA, Roberto. A economia da informação. In. AMBROSI, A.; PEUGEOT, V.; PIMIENTA, D. (Coord) Desafios de palavras: enfoques multiculturais sobre as sociedades da informação. Caen-France: C \& F Éditions, 2005. Disponível em: http://vecam.org/archives/article726.html. Acesso em: 01 ago. 2016.

WERTHEIN, Jorge. A sociedade da informação e seus desafios. Ci. Inf., Brasília, v. 29, n. 2, p. 71-77, maio/ago. 2000. Disponível em: http://www.scielo.br/pdf/ci/v29n2/a09v29n2.pdf. Acesso em: 01 ago. 2016.

WHITE, Larry Nash. An old tool with potential new uses: return on investment. The Bottom Line: Managing Library Finances, v.. 20, n.1, 2007, p. 5-9. 